\title{
TRABALHADORES RURAIS VOLANTES DA REGIÃO DE JABOTICABAL: CRESCIMENTO, CARACTERISTICAS E ASPECTOS ORGANIZACIONAIS
}

\author{
JOSE GIACOMO BACCARIN
}

Orientador: Prof. Dr. ORIOWALDO QUEDA

\begin{abstract}
Dissertação apresentada à Escola Superior de Agricultura "Luiz de Queiroz", da Universidade de São Paulo, para obtenção do título de Mestre em Agronomia. Área de Concentração: Economia Agrária.
\end{abstract}

PIRACICABA

Estado de São Paulo - Brasil

Maio - 1985 
A Mirian, companheira de todos os momentos, sempre $\therefore$

segurando a barra dē um marido

nervoso e "encucado" e-também

pela nossa união tão forte e amorosa.

A Mariana, Maria Clara e Pedro, pelas mudanças, maus-humores e omissões que tiveram que suportar para que o pai fizesse o curso de Pós-Graduação.

Aos companheiros de Pós-Graduação, especialmente o Barnes, o Rafael, - Bob, o João Aurélio e o Vicente pela amizade e boa convivencia sem pre presente, apesar da competiti vidade do Pós-Graduação. 


\section{A G R A D E C I MENTOS}

Apesar da individualização da autoria, esta dis sertação resulta de um esforço coletivo de trabalho com parti cipação acentuada dos Professores Argemiro Oliveira Sousa, Jo sé Jorge Gebara e Maria Madalena Zocoller (companheiros de dis cussão e de trabalho do Departamento de Economia.Rural da FCAVJ/UNESP), de alunos do curso de Agronomia da FCAVJ e de companheiros da Comissão Pastoral da Terra. A todos eles meus agradecimentos e minha estima.

Não poderia deixar de agradecer especialmente ao Gebara, colega, compadre e amigo. Sua paciência, seu equi líbrio, suas preocupações sociais foram sempre suporte e estí mulo a esta dissertação e contribuiram para selar entre nós uma inestimável amizade.

Aos trabalhadores rurais volantes, bóias-frias, objetos deste trabalho, que sempre nos receberam bem e tiveram paciência de nos revelar seu sofrido mundo. Nesta dissertação vai embutida a esperança de uma sociedade justa e iguali tária, que não considere o trabalhador como cidadão de tercei ra categoria *

Ao Queda, orientador desta dissertação, por ter dado liberdade de trabalho ao seu teimoso orientado e por sem pre ter mostrado em nossas discussões que as ciências sociais não comportam verdades absolutas e acabadas, que nossas preten sas certezas e respostas devem ser sempre relativizadas por outros conhecimentos e outros fatos da realidade social.

Ao Prof. Rodolfo Hoffmann pelas valiosas suges töes e críticas, muitas das quais foram incorporadas neste tra 
balho. Também pela sua extrema racionalidade e precisão no julgamento desta dissertação.

Ao Aparecido Luiz Cremonez, datilógrafo preciso e paciente, que depois destádissertação está conseguindo dis tinguir quase sempre meu a do meu o.

Aos demais colegas do Departamento de Economia Rural da FCAVJ/UNESP (Antonio Carlos Manduca Ferreira, Francis co Graziano Neto, João Luiz Cardoso, José Roberto Medina Lan dim, Manoel Antonio de Almeida Monteiro, Tsunehisa Tamaki) pe la cordial convivência e por terem assumido minhas obrigações docentes na época do afastamento para a Pós-Graduação.

Ao CNPq e à CAPES pelo auxílio financeiro atra vés da concessão de bolsas de estudo... 
2 - trabalhador volante: conceitos, características e E $\underline{X}$

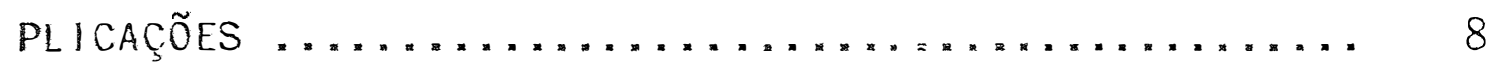

2.1. Conceitos e Características dos Bóias-frias .... 12

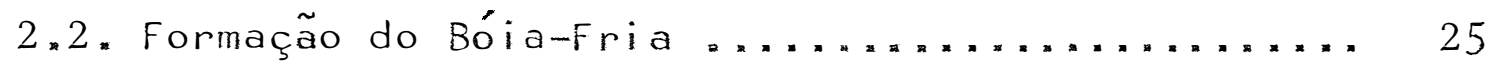

2.3 . Conceito Síntese e Hipóteses $\ldots \ldots \ldots \ldots \ldots \ldots \ldots \ldots \ldots$

3 - AS TRANSFORMAÇÕES NA AGRICULTURA E AS RELAÇÕES DE TRA BALHO NO MUNICÍPIO DE JABOTICABAL $\ldots \ldots \ldots \ldots \ldots \ldots \ldots \ldots$ 3.1. Utilização da Área Agrícola de Jaboticabal . * " " 42 3.2. A Distribuição da Posse e Propriedade da Terra

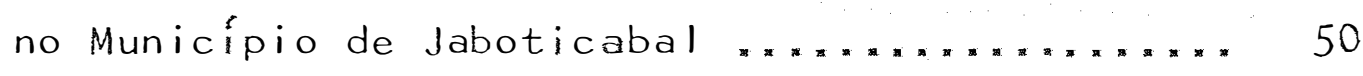

3.3. A Técnica na Agricultura de Jaboticabal ....... 54 3.3.1. Técnicas Usadas na Cana-de-Açúcar ....... 60 3.4. População e Relações de Trabalho na Agricultura

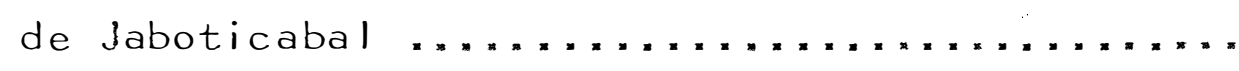

4 - O MERCADO DE TRABALHO VOLANTE E AS CARACTER ÍSTICAS

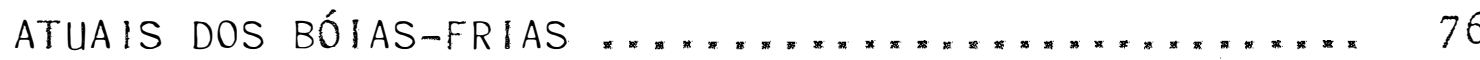


4.1. O Mercado de Trabalho Volante e as Formas de Contratação dos Bóias-Frias .............. 78

$4 \ldots 2$. Condições de Trabalho .................... 89

4.3. Procedência, a Família e Condições de Vida .... III

5 - REIVINDICAÇÕES E MOBILIZAÇÃO DOS BÓIAS-FRIAS ........ 124

5.1. As Reivindicações e as Dificuldades de Mobiliza ção dos Bóias-frias $\ldots \ldots \ldots \ldots \ldots \ldots \ldots \ldots \ldots \ldots \ldots \ldots$

5.2. Os Movimentos de Guariba e Bebedouro .......... 135

5.2.1. A Revolta de Guariba ............. 137

5.2.2. A Revolta de Bebedouro ............ 142

5.2.3. Consequencias e Perspectivas .......... 144

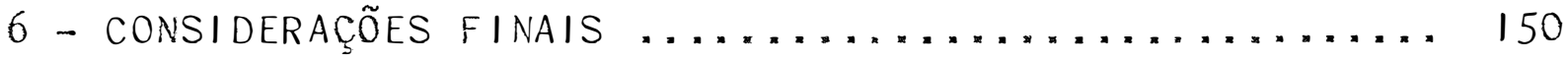

7 - LITERATURA CITADA $\ldots \ldots \ldots \ldots \ldots \ldots \ldots \ldots \ldots \ldots \ldots \ldots \ldots \ldots \ldots$ 
Trabalhadores Rurais Volantes da Região de Jaboticabal: Cresci mento, Características.e Aspectos Organizacionais

$\begin{array}{ll}\text { Autor } & \text { José Giacomo Baccarin } \\ \text { Orientador } & \text { Oriowaldo Queda }\end{array}$

Este trabalho trata do trabalhador volante ou bóia-fria na agricultura, tomando-se como universo empírico ba sicamente o município de Jaboticabal (SP). Foram analisadas as transformações da agricultura do município a partir de 1940 e seus efeitos sobre a formação da categoria dos volantes lo cal, as condições atuais de vida e trabalho dos bóias-frias bem como as suas reivindicações e a sua organização política. Além de dados de Censos Agropecuários, foram utilizados dados primários obtidos através de questionários aplicados a 50 trabalhadores bóias-frias em agosto de 1983. Destes, II foram selecionados e acompanhados com entrevistas bimensais até agosto de 1984. A análise permitiu chegar a a guns resultados e conclusões, apresentados a seguir.

De 1940 em diante as principais alterações ob servadas na agricultura do município foram a expansão da cultú ra da cana-de-açúcar, o aumento do tamanho médio dos estabele cimentos, o crescimento na utilização de técnicas químicas e mecânicas e o aumento da participação do trabalho assalariado, 
especialmente o temporário, na força de trabalho da agricultu ra. Em 1980, mais da metade da força de trabalho agrícola do município se constituia de bóias-frias.

As condições de trabalho dos bóias-frias apre sentam variações ao-longo de um ano,podendo considerar-se dois períodos básicos. Um deles, o da safra da cana-de-açúcar e da Iaranja, onde o mercado de trabalho volante é mais organizado, com maiores vínculos formais de emprego, maior estabilidade e com pequena participação do empreiteiro individual de mão-deobra. No outro período, a entressafra, ocorre maior instabili dade de emprego, os contratos de trabalho, em sua maior parte, não são formalizados e o empreiteiro individual volta a ter im portância fundamental na organização deste mercado. Dos volan tes entrevistados, $94 \%$ revelaram ganhar menos que 3 salários mínimos no período da safra, sendo que na entressafra a tendên cia observada foi de achatamento deste nível salarial.

As condições de vida dos entrevistados revela ram-se precárias, caracterizando-se principalmente pelo alto grau de anafalbetismo e semi-anafalbetismo e por problemas de deficiência nutricional. A fome foi constatada várias vezes, especialmente na entressafra.

Os movimentos reivindicatórios dos bóias-frias observados na região sempre se caracterizaram por envolverem pequeno número de trabalhadores e serem isolados. Na safra de 1984, ocorreram movimentos abrangentes, iniciados pelos apanha dores de Iaranja em Bebedouro e pelos cortadores de cana de Guariba e que tenderam a envolver toda a categoria de trabalha dores volantes. As relações entre empresários e trabalhadores mudaram a partir de então, com início de negociações coletivas sobre as condições dos contratos de trabalho. 


\section{RURAL TEMPORARY WORKERS IN THE REGION OF JABOTICABAL: GROWTH, CHARACTERISTICS, AND ORGANIZATION.}

\section{Author: José Giacomo Baccarin Adviser: Oriowalvo Queda}

This study dealt with the rural hired labor force in the municipality of Jaboticabal, State of São Paulo. The changes which have taken place in the agriculture of that municipality from 1940 to date, and the effects of these changes on the local labor force and on worker's current living and working conditions, as well as their demands and political organization were analyzed.

The data utilized in this study was taken from the IBGE Agricultural Census and also primary data were obtained by interviewing fifty temporary workers in August, 1983. In addition, eléven workers were selected from that group to be interviewed every two months, up to August 1984 .

The main changes which occurred in agriculture in that municipality are: the expansion of sugarcane cropping: increased utilization of chemical and mechanical techniques; increased participation of hired labor force, especially of temporary workers; in fact, in 1980 over half of the rural labor force in that municipality was made up of temporary workers.

The working conditions of temporary workers change during the year, where two basic distinct periods may be 
considered: a) the sugarcane and orange harvest seasons, in which the temporary worker market is better organized, and there are formal employment links, a higher stability and a lower participation of contractors; b) the off-season, in which there is a greater employment instability, most employment contracts are not formalized,and contractors once again gain importance in organizing the market. It was found that $94 \%$ of the workers interviewed earned less than three times the value of the minimum wage during the harvest season, and much less in the off-season.

The high illiteracy or quasi-illiteracy levels found, along with mal nutrition are associated with the very poor living conditions of the workers interviewed. Several cases of near-starvation were found, mainly in the off-season period.

Although there have been some temporary worker picketing and other claim movements in the region, these have been of a dispersed nature and involved a low number of workers. In the 1984 harvest season, however, movements tending to involve the whole class of temporary workers were initiated by orange pickers in Bebedouro and sugarcaneharvesters in Guariba. After that, the relationship between employers and temporary workers has changed, and employment contract arrangements are being negotiated collectively. 
1 - INTRODUÇÃO

A participação dos trabalhadores rurais volan tes ou bóias-frias no total da força de trabalho empregada na agricultura brasileira passou por intenso crescimento após 1960, especialmente em regiões de agricultura mais intensiva. No Estado de São Paulo, em 1981, cerca de $26 \%$ da força de trạ balho empregada na agricultura se constituía de volantes, sen do que na Divisão Regional Agrícola (DIRA) de Ribeirão Preto esse valor se elevava para aproximadamente 50\% (IEA, 1982).

Estudando a evolução da composição da força de trabalho agrícola no período $1964 / 75$ para o Estado de São Pau Io, GRAZIANO DA SILVA \& GASQUES (1982:90) afirmam que "em I। anos, a populáção ocupada na agricultura paulista reduziu-se do índice 100 para 96, sendo que os residentes no imóvel redu ziram-se a menos da metade e os não-residentes aumentaram em 
quase $30 \%$. Como consequência, a composição relativa evoluiu no sentido de maior participação dos trabalhadores não-residen tes que passaram de 15,8\% a 33,1\% da mão-de-obra ocupada no pe ríodo. A relação entre o número de trabalhadores residentes e não-residentes baixou de 5,4 para 2,0 nesse período. Observase que os trabalhadores volantes representavam, em 1975, mais de um quarto da força de trabalho ocupada na agricultura pau lista".

O crescimento da participação dos volantes na força de trabalho do Estado de São Paulo não se deu com a mes ma intensidade em todas as suas regiões. Analisando as DIRAs do Estado no período 1970-75, ANTUNIASI (1976:10) constatou "aumentos mais significativos dos volantes nas regiões urbani zadas e industrializadas como Campinas $(11,52 \%$ para $33,56 \%$ do total de trabalho efetivo), Ribeirão Preto $(25,81 \%$ para $47,85 \%)$ e Vale do Paraíba $(3,35 \%$ para $9,28 \%)$, justamente as áreas em que se registraram maiores quedas na utilização de mão-de-obra de parceiros e arrendatários. Nota-se que são áreas industria lizadas em que a cultura da cana se faz presente de forma sig nificativa */. (Grifado na transcrição). Em contraste a estas regiões, situava-se a DIRA de Presidente Prudente, que apresen tou o menor aumento relativo do porcentual de utilização de mão-de-obra volante na agricultura.

A formação da categoria de trabalhadores volan tes tem sido explicada como resultado do processo de transfor

* A colocação da DIRA do Vale do Pará́ba na mesma situação das DIRAs de Campinas e Ribeirão Preto se mostra,. forçada. Sua agricultura é menos intensiva e-a cana-de-açúcar tem pequena expressão no local. 
mações capitalistas pelo qual passou a agricultura brasileira, que implicou na substituição de antigas relações de trabalho

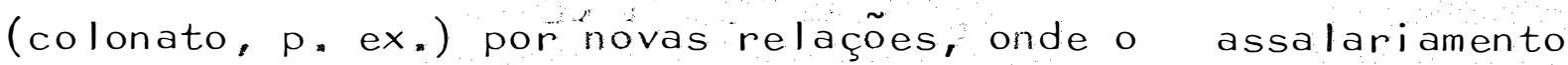
monetário torna-se quase que exclusivo (BRANT, 1977; GONZALES \& BASTOS, 1982). Os dois últimos autores colocam o trabalho volante como uma forma concreta de relação social de produção capitalista, a qual pressupõe, por um lado, um mínimo e sempre crescente volume de capital nas mãos dos empresários agrícolas e, por outro, um contingente de trabalhadores despojados de seus meios de produção.

Como componente do proletariado o bóia-fria tem sido singularizado pela instabilidade de emprego a que está su jeito, o que, unido aos baixos salários recebidos, faz com que esta categoria apresente precárias condições de vida e traba Iho. O trabalho instável e incerto, que estimula forte compe tição entre os trabalhadores pelos empregos existentes, difi culta a organização do bóia-fria como categoria e diminui seu poder reivindicatório. Ao mesmo tempo, da precariedade da existência do bóia-fria resulta um foco de constante tensão so cial e desejos de mudanças prementes, o que tem resultado, mais recentemente, em movimentos reivindicatórios com alto grau de violência. No ano de 1984 ocorreram revoltas dos volantes em vários locais do Centro-Sul do País, atingindo áreas produto ras de café, laranja e cana-de-açúcar, entre outras. Desta cou-se o movimento dos cortadores de cana que atingiu o Estado de São Paulo (Região de Ribeirão Preto, principalmente), o Sul de Goiás e a Região de Campos (RJ), sendo que, especialmente na cidade de Guariba (SP), a violência do movimento foi eleva da com a ocorrência de saques, depredações, sabotagens (queima 
de canaviais) e conflitos armados entre trabalhadores e poli ciais.

Na tentativa de se conhecer melhor esta realida de social, procurando maior entendimento da formação, da vida e das reivindicações e organização dos bóias-frias é que se de senvolve este estudo tomando-se como universo empírico o mun cípio de Jaboticabal (SP).

Este estudo pretende especificamente analisar:

a) as transformações ocorridas na agricultura do município a partir de 1940, especialmente no que se refere à composição do produto agrícola, distribuição da posse da ter ra e desenvolvimento técnico, relacionando-as com as altera ções verificadas nas relações de trabalho da agricultura lo cal;

b) as condições de trabalho (formas de contrata ção, período de emprego, jornada de trabalho etc.) e as condi ções de vida (educação, saúde, moradia e nutrição) dos bóiasfrias de Jaboticabal;

c) as reivindicações dos trabalhadores, sua or ganização e os movimentos reivindicatórios, especialmente dos cortadores de cana de Guariba e apanhadores de laranja de Bebedouro :

Embora o universo empírico considerado tenha si do Jaboticabal, sempre que possível e necessário utilizam-se in formações referentes a municípios próximos, como Guariba e Be bedouro * Esses três municípios pertencem à Divisão Regional Agrícola (DIRA) de Ribeirão Preto, situada no Nordeste do Esta do de São Paulo e que se caracteriza pela grande produção agrí cola (entre as DIRAs estaduais, Ribeirão Preto é a primeira 
produtora de amendoim, cana-de-açúcar, laranja, milho e soja, segunda produtora de arroz e café, terceira de algodão e quin ta de feijão, IEA: 1983) e pelos altos índices de tecnificação de sua agricultura.

Dentro da DIRA distinguem-se 5 sub-regiões, ca da uma situada próxima, respectivamente, à cidade de Franca, onde predomina o café; à cidade de Orlândia, com destaque para soja e milho; a São Carlos, com predomínio da pecuária leitei ra; a Bebedouro, onde a laranja ocupa a maior parte da área agrícola e a parte central da DIRA, próxima à cidade de Ribe rão Preto, onde se destaca a cultura da cana-de-açúcar.

0 município de Jaboticabal se encaixa nesta úl tima sub-região, sendo que, em 1980, a cultura da cana-de-açú car ocupava 31.250 ha, representando $53 \%$ da área total de la vouras do município (FIBGE, 1980).

Embora a cultura da laranja não seja tão expres siva em Jaboticabal - em 1980 ocupava 2.496 ha ou 4,2\% da área de lavouras do município (FIBGE, 1980) - parte considerável dos volantes locais se desloca diariamente para alguns municí pios vizinhos, especialmente Bebedouro, para trabalhar. na colheita daquele produto.

É sabido que a produção de cana-de-açúcar assim como a da laranja, se faz com a utilização intensa do trabalhạ dor volante, especialmente em suas colheitas. E basta recor dar a informação anteriormente apresentada de que cerca de 50\% da força de trabalho ocupada na agropecuária da DIRA de Ribei rão Preto se constituem de volantes, para se constatar a impor tância destes trabalhadores na agricultura de Jaboticabal. 
o trabalho inicia-se com um capítulo que, revi sando a literatura pertinente, procura discutir conceitos, ca racterísticas e explicações sobre o crescimento do bóia-fria na agricultura brasileira. Este capítulo serve como suporte teórico ao restante do trabalho e ao seu final algumas hipóte ses são estabelecidas.

Os três capítulos seguintes analisam as evidên cias para o município de Jaboticabal, sendo que o primeiro re fere-se ao estudo das transformações da agricultura e altera ções nas relações de trabalho do município no período de $1940-$ 80, tendo sido utilizados dados secundários obtidos da Funda ção Instituto Brasileiro de Geografia e Estatística (FIBGE). Estes dados foram complementados com informações obtidas de questionários aplicados a trabalhadores e proprietários rurais mais velhos que vivenciaram as mudanças no período, conseguin do-se assim melhor qualificação dos dados fornecidos pelos Cen sos Agrícolas.

Nos outros dois capítulos de evidências, são analisadas, respectivamente, as condições de trabalho e de vi da dos bóias-frias locais e as reivindicações e organização destes trabalhadores. Os dados, neste caso, foram obtidos, inicialmente, pela participação do autor em reuniões da Comis são Pastoral da Terra (CPT), do Sindicato de Trabalhadores Rú rais (STR), em passeatas reivindicatórias e em outras ativida des desenvolvidas pelos volantes, bem como pelo contato direto com trabalhadores, empreiteiros e proprietários rurais.

Também se realizou aborgagem mais sistematizada ou formal dos trabalhadores pela aplicação de questionários a 50 bóias-frias em agosto de 1983. Neste caso tomou-se o cuida 
do de selecionar trabalhadores de diferentes bairros da cidade de Jaboticabal que trabalhassem para diferentes empregadores e na medida do possível, em diferentes culturas.

Dos 50 questionários iniciais foram seleciona dos 11, cujos trabalhadores entrevistados foram acompanhados no período de umano, até agosto de 1984, com 6 entrevistas bi mensais. O objetivo foi o de aprofundar as informações obti das inicialmente, além de poder acompanhar as variações de em prego do volante durante o ano, especialmente entre os perío dos da safra e entressafra da cana e da laranja.

Embora a amostra seja pequena, acredita-se que a confiabilidade das informações é grande, mesmo porque os con tatos informais já referidos serviram também para confirmar as informações obtidas nos questionários. 
2 - TRABALHADOR VOLANTE: CONCEITOS, CARACTERÍSTICAS E EXPLICA ÇÕES

A uti lização de trabalhadores temporários ou vo lantes na agricultura não é algo recente. MARX (1982, cap. XXIII) relata a existência de um tipo de trabalhador na agri cultura britânica na primeira metade do século passado, consti tuindo os chamados "bandos ambulantes" que, morando nas cida des, se deslocavam diariamente - quando havia disponibilidade de emprego - para os serviços no setor rural, sendo caracterís tica na vida destes trabalhadores a intermitência dos vínculos de emprego.

Também Max Weber descreve a existência de tra balhadores sazonais na agricultura alemã no final do século passado. Para o autor "o problema mais importante que qual quer constituição do trabalho no campo tem que resolver, em 
especial nas grandes unidades agrícolas que utilizam, não a força de trabalho familiar do proprietário, mas exclusivamente a força de trabalho alheia, é a questão da distribuição desi gual de trabalhadores requeridos em cada uma das estações do ano (...). Por isso, via de regra, a agricultura, especialmen te a da grande propriedade, além do conjunto fixo de trabalha dores, permanentemente à disposição da propriedade e ocupados todo o ano, necessita periodicamente de força de trabalho adi cional; e as peculiaridades típicas de qualquer constituição do trabalho estão fundamentadas nas formas de suprimento des tes dois tipos de demanda da força de trabalho" (WEBER, 1981: 29). E conforme afirma o autor, a força de trabalho adicional necessitada pela agricultura alemã era suprida ou por trabalha dores já totalmente proletarizados que se deslocavam de fazen da em fazenda ou por pequenos produtores que migravam sazonal mente para outras propriedades, com a finalidade de complemen tar os seus rendimentos.

Na análise de Karl Marx a existência dos "ban dos ambulantes" ou dos trabalhadores temporários,como parcela do proletariado, resulta do processo de acumulação de capital que, diminuindo a parte variável do capital e, em consequencia elevando sua composição orgânica, aumenta o exército de reserva de mão-de-obra e o número de desempregados. Acumular é, por tanto, aumentar o proletariado que passa a contar somente com sua força de trabalho para sobreviver, recebendo em troca de sua venda no mercado de trabalho mero salário de subsistência. "A acumulação de riqueza num polo é ao mesmo tempo aumento da miséria, de trabalho atormentante, de escravatura, ignorância, brutalização e degradação moral, no polo oposto, constituído 
pela classe cujo produto vira capital" (MARX, 1982:749).

0 processo de acumulação de capital, gerando ex cedente de mão-de-obra, é compensado pela criação de novos ra mos produtivos e pela ampliação de outros. Na agricultura es ta compensação não se dá em seu interior, pois a criação de novos ramos produtivos ocorre basicamente no setor urbano. As sim, a penetração do capital na agricultura apresenta como con sequência a expulsão de parcella da população rural.

Analissando especificamente a agricultura da In glaterra, MARX (1982) afirma que a formação de uma população supérflua nos campos, que é expulsa em direção às cidades, re sulta principalmente da concentração dos arrendamentos, da transformação de lavouras em pastagens e do emprego de maquina ria. Ou seja, a proletarização decorre da concentração da pos. se da terra, da alteracão na composicão do produto agrícola e da mecanização.

Ao mesmo tempo que parcela da população agríco la era expulsa em direção ans centros urbanos, em algumas fá ses do ciclo agrícola os empresários necessitavam de braços ex tras para as operações das lavouras. Os arrendatários ingle ses solucionavam este problema, mantendo em suas posses apenas os trabalhadores especializados e, quando a necessidade de bra ços aumentava, especialmente nas colheitas, usavam trabalhado res extras provenientes das cidades, agrupados nos "bandos am bulantes": Estes se compunham de 10, 40, 50 pessoas comanda

*/ "Meu arrendamento se estende por 320 acres, tudo terra para plantar trigo. Não tem nenhuma habitação. Um trabalhador mora comigo. Quatro que trabalham com cavalos estão aloją dos nas proximidades " O trabalho leve é feito pelos bandos" Palavras de um arrendatário inglês, citados por MARX (1982: 807): 
das por um chefe que ajustava o serviço por empreitada com o arrendatário. Todo início de dia os bandos saíam das cidades, andando 3-4 milhas até o local de trabalho e no final do dia voltavam para suas moradias..

Na agricultura da Irlanda, conforme relata MARX (1982), também se verificou o processo de expulsão da popula ção rural, especialmente devido à introdução de pastagens em larga escala. Parcela desta população, que passava a habitar o setor urbano, voltava em épocas de maiores necessidades de mão-de-obra, a trabalhar temporariamente no meio rural. "Todo ano as cidades tinham de receber o que se considerava exceden te de trabalhadores, e havia gente que se suppreendia por ha ver excesso de trabalhadores nas cidades e aldeias e carência nos campos. A verdade é que só se sente essa carência por oca sião de trabalhos prementes da lavoura na primavera e no outo no; ficando muitos braços ociosos no resto do ano; que após a colheita, de outubro até a primavera, praticamente não há em prego, e que os trabalhadores durante o tempo em que estão ocu pados frequentemente perdem dias inteiros e ficam sujeitos a toda espécie de interrupções" (MARX, 1982:822). Ficam eviden ciadas na vida do trabalhador irlandês a incerteza e irregula ridade de ocupação, as interrupções do trabalho, freqüentemen te repetidas e longas, todos esses sintomas de uma superpopula ção relativa.

O processo de expulsão da população rural e for mação dos excedentes de mão-de-obra apresentava semelhanças na Inglaterra e Irlanda Entretanto, enquanto o primeiro país se industrializava rapidamente, o segundo se mantinha essencia mente agrícola, implicando em diferenças na absorção do exce 
dente de mão-de-obra. "Mas há uma diferença: na Inglaterra, país industrial, sua reserva industrial é recrutada nos campos; na Irlanda, país agrícola, a reserva da agricultura é recruta da nas cidades, onde se refugiam os trabalhadores agrícolas enxotados. No primeiro país, os braços supérfluos da agricul tura se convertem em trabalhadores de fábrica; no segundo, os que foram tangidos para as cidades, ao mesmo tempo que pressio nam no sentido de rebaixar os salários urbanos, continuam sen do trabalhadores agrícolas e voltam constantemente aos campos à procura de trabalho" (MARX, 1982:823).

Conforme demonstram os relatos de Karl Marx e de Max Weber, a utilização de trabalhadores temporários na agricultura tem sido constatada em diferentes momentos históri cos e se relaciona ao processo de penetração capitalista na agricultura. No Brasil, o trabalhador temporário torna-se mais evidente e significativo, após 1960, quando se acentua a moder nização da agricultura brasileira. Guardadas as devidas pro porções entre os diferentes momentos históricos considerados, a formação e mesmo algumas das características do trabalhador temporário no Brasil apresentam semelhanças com a dos trabalha dores temporários da agricultura britânica e alemã do século passado. No restante deste capítulo, discutir-se-ão conceitos, características e a formação do trabalhador temporário oubóiafria na agricultura brasileira.

2.1* Conceitos e Características dos Bóias-Frias

Em um dos primeiros estudos sobre o bóia-fria, 
realizado em Piracicaba no ano de 1966; Bombo e Brunelli, cita dos por SAINT (1980:504), definem os volantes como sendo: "pes soas com empregos periódicos e relações de trabalho informais que vivem fora do estabelecimento rural em que trabalham, habi tualmente na periféria de cidades próximas".

Nesta definição dois aspectos são destacados: a precariedade de emprego e a moradia fora do setor rural, fazen do com que o vínculo do bóia-fria com o setor rural não seja permanente e criando a possibilidade do bóia-fria também poder ser empregado pelo setor urbano. Desta forma, o bóia-fria re presentaria a unificação do mercado de trabalho da economia, podendo ser usado tanto pelo setor rural como pelo setor urba no. "A característica singular do trabalhador volante é que, apesar de ser um assalariado rural, tem o seu custo de reprodú ção determinado ao nível do setor urbano... Ele personifica a união entre o proletário rural e urbano no sentido de que for ça a convergência do custo de reprodução da mão-de-obra entre agricultura e indústria. Ou seja, a disseminação do trabalha dor volante na agricultura implica a unificação do mercado de trabalho de toda a economia, com os benefícios que daí derivam para o capital" (GRAZIANO DA SILVA, 1982:155).

A não existência de vínculos permanentes de em prego obriga os volantes a constantes deslocamentos à procura de serviço. Isto fica explicitado na definição de GONZALES \& BASTOS (1982:38) que consideram o bóia-fria "como uma relação de trabalho na qual os produtores diretos vivem exclusivamente da venda de sua força de trabalho e, para tanto, são obrigados a se deslocarem continuamente, seja de um local fixo a diferen tes lavouras, ou de uma fazenda a outra; a fim de executarem 
tarefas em regime de empreitada direta ou intermediada"*

Nesta colocação fica reforçada a idéia de que o volante representa a "unificação do mercado de trabalho de to da a economia" pelo fato de poder se deslocar, além de empre gos no setor urbano para o rural, entre as empresas do setor rural. Assim, estaria caracterizada uma massa de trabalhado res disponíveis, "Iivres" da posse dos meios de produção e que, na medida das necessidades, pode ser utilizada pelos di versos ramos da economia.

Tanto GONZALES \& BASTOS (1982), como GRAZIANO DA SILVA (1982) e KAGEYAMA (1982) reforçam a idéia de que o trabalhador volante se encontra totalmente despojado dos meios de produção, distinguindo-o do "trabalho sazonal" ou "assala riamento temporário" " Nesta modalidade encontram-se os parce ros e pequenos proprietários que não conseguem subsistir exclu sivamente como tais e que, portanto, necessitam de complemen tar os seus rendimentos como assalariados, em determinadas épo cas do ano. Diferentemente dos volantes, estes indivíduos não estão desprovidos totalmente dos meios de produção. Teorica mente, esta distinção teria importância por separar duas clas ses sociais (camponeses pobres e proletários) que poderiam apresentar diferentes interesses políticos.

Nas conceituações sobre trabalhador volante en contradas na literatura, uma característica sempre citada se refere à precariedade e à instabilidade de emprego. Esta idéia

* Os trabalhadores que se deslocam de um local fixo (urbano) para executarem tarefas na área rural, os autores designam por "rurbanos", enquanto os que se deslocam periodicamente de uma fazenda a outra, hospedando-se provisoriamente nos locais de trabalho, são chamados "itinerantes". 
é destacada, por exemplo, por D'INCAO E MELLO (1975:100) afir mando que "o bóia-fria é contratado para desempenhar determina da tarefa, num curto espaço de tempo e sem qualquer vínculo de. natureza trabalhista com o empregador": (Grifado na transcri ça).

A mesma perspectiva, embora mais detalhada, é apresentada por IANNI (1974:41) ao dizer: "o que singulariza o béia-fria, em face de outros setores do proletariado rural e também industrial $\ldots=(e ́$ que)... ele é um trabalhador que rece be seu salário com base na realização de tarefa ou empreita; é contratado - verbalmente antes do que por escrito - por tempo limitado, tempo esse que pode durar dias, semanas, meses, mas

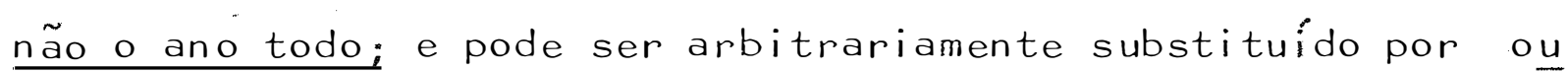
tro trabalhador, se não realizar a tarefa ou empreita a conten to do empreiteiro de mão-de-obra, fazendeiro, usineiro, dono da terra ou plantação. São instáveis os seus vínculos emprega tícios com os compradores de sua força de trabalho" " Grifado na transcrição).

- tipo de remuneração mais típica do volante é a por empreita ou tarefa (colheita da cana, café, laranja, amen doim, milho, raleação do algodão, etc.), embora também ocorra o pagamento por diária fixa, especialmente nas capinas. O pa gamento por tarefa ou empreita traz grande vantagem ao produ tor pois estimula o bóia-fria a produzir o máximo possível em seu dia de trabalho, realizando mais trabalho excedente, do qual resultam lucros maiores para o empresário agrícola. "As sim, as condições sob as quais o bóia-fria é empregado garán tem que ele realize (com bastante autonomia ou reduzidos cons trangimentos, por párte do gato ou do proprietário) o máximo possível de trabalho excedente..." (IANNI, 1977:44). 
IANNI (1977:43) vai adiante com o seu raciocí nıo, dizendo que "o que singulariza o bóia-fria é que ele é produtor de mais-valia absoluta", posto que "seu trabalho é minimamente potenciado por um outro instrumento". Esta afirma ção sugere a não ocorrência de aumento da produtividade do tra balho nas operações realizadas pelo bóia-fria, sendo que isso nem sempre é a realidade. Como se verá com maiores detalhes posteriormente, o corte manual da cana-de-açúcar, por exemplo, teve o rendimento do trabalhador duplicado a partir da adoção da queima dos canaviais.

De qualquer maneira, dado um determinado nível de técnica, o pagamento por produção estimula o bóia-fria a trabalhar até o limite de sua força física, beneficiando o processo de acumulação capitalista. Do ponto de vista da ra cionalidade do capital, o volante representa a vantagem de so mente ser pago em troca da concretização do trabalho. (pagamen to por tarefa), além de ser contratado somente nos momentos de necessidade prementes de mão-de-obra, implicando a redução do custo de produção.

Além da jornada de trabalho, que tende a ser alongada para aumentar o seu ganho, o volante perde boa parte do seu dia no transporte da moradia, nos centros urbanos, para o local de trabalho, no setor rural, e vice-versa. 0 - 0 trans

* Para a Região da Alta Sorocabana, D'INCAO E MELLO (1975) es timou uma jornada de trabalho de 10 a 12 horas, à qual se acrescentava o tempo gasto com o transporte, totalizando 15 a 16 horas diárias. Para a Região de Avaré e Cerqueira Ce sar GRAZIANO DA SILVA \& FREITAS (1976) calcularam que, em média, o volante fica "fora de casa" 12 horas, para um pe ríodo de trabalho efetivo de 8 horas. 
porte é realizado, normalmente, em caminhões lotados, muitos dos quais em precárias condições de conforto e segurança, oca sionando desgaste extra de energia ao volante e, repetidas ve zes, acidentes com vítimas fatais.

Os conceitos até aqui apresentados caracterizam o mercado de trabalho volante pela instabilidade de emprego e pela inexistência de vínculo empregatício formal. o trabalha dor se vê obrigado a mudar constantemente de emprego entre as empresas do setor rural e, algumas vezes, trabalhar em servi ços urbanos, sendo comum passar por fases de desemprego puro e simples. Além disso,fica sujeito aos rigores climáticos, sen do que quando chove, por exemplo, näo trabalha e nada ganha * A organização deste mercado, pela sua própria instabilidade, depende em grande parte do empreiteiro de mão-de-öbra que arre gimenta, transporta, fiscaliza, gerencia e mesmo distribui a mão-de-obra disponível entre as propriedades agrícolas, $\because$ de acordo com a época e o número de trabalhadores necessários. Isto garante grande autonomia ao empreiteiro ou gato que, rece bendo porcentagem do salário do volante e controlando número considerável de trabalhadores, pode vir a pressionar os salá rios para cima, representando ameaça ao lucro do empresário agrícola.

*) O gato tem sido descrito, muitas vezes, como, ladrão do ga nho do bóia-fria. Sua atuação, entretanto, é mais comp $x a$; conhecem-se casos, inclusive, onde ele organizara, gré ves dos trabalhadores para que se aumentasse os śalários destes. Não se pode esquecer que a exploração se dá na re lação empresário agrícola - trabalhador volante, servindo o gato de mero intermediárió Vide zOCOLLER et alii (1984). 
Essas duas características típicas do mercado de mão-de-obra volante - a instabilidade de emprego e a infor malidade de vínculo empregatício - merecem ser melhor discuti das. Pode-se começar pela informalidade do contrato de traba I ho,

Alguns autores consideram que a contratação dos volantes por empreita ou tarefa dissimula a relação de emprego, posto que na aparência a relação entre bóia-fria e proprietá rio passa a ser societária. "A Legislação Trabalhista Brasi Ieira, ou mais precisamente, o Estatuto do Trabalhador Rural não considera a relação de trabalho em regime de empreitada (eventual, temporário, volante, etc) como uma relação de empre 90. Juridicamente a relação de emprego implica em vínculo de permanência, individualidade, subordinação, dependência hierár quica, salário, etc. 0 que a relação de trabalho por tarefa, na aparência não apresenta. Assim, esta relação de trabalho sai do domínio da Lei Trabalhista e se dissolve na Lei Comum através dos chamados 'contratos agrários', quando existem" (GON ZALES \& BASTOS, 1982:40). Além disso, a presença do gato, in termediando a relação de emprego entre proprietário e bóiafria, também tem servido de justificativa para se tentar deso brigar o contratante dos encargos trabalhistas.

Na realidade, entretanto, como os próprios auto res acima citados reconhecem, o salário por tarefa é um modo transfigurado do salário controlado por tempo que existe onde o trabalhador vende sua força de trabalho, ou seja, o pagamen to do trabalho volante por tarefa não lhe retira o caráter es sencial de trabalho assalariado. E é assim que a Justiça tem entendido a relação entre bóia-fria e proprietário, existindo 
jurisprudência firmada que garante ao volante todos os direi tos dos trabalhadores rurais previstos no Estatuto do Trabalha dor Rural (ETR); mesmo em caso de ação judicial a resporsabili dade legal é do proprietário. e não do turmeiro, já que este é considerado mero preposto daquele (FREMAS \& ARANHA, 1975; FREI TAS, 1977).

A existência de amparo legal, contudo, não é ga rantia de que os bóias-frias se empreguem com os direitos tra balhistas assegurados. Grande parte deles ainda trabalha sem carteira de trabalho assinada, recebendo só o dia de trabalho, sem receber o 13o salário, férias, descanso semanal, etc.

Quanto à instabilidade de emprego, encontram-se citações na literatura de casos onde os volantes apresentam vínculos mais permanentes com o proprietário, trabalhando na mesma propriedade por perfodos superiores a 1 ano, constituin do as chamadas turmas firmes. "Investigação recente apurou que a natureza temporária e curta desses grupos de trabalho (volantes) não é nem de longe tão generalizada como se pensava inicialmente. Numa série de casos, verificou-se que o grupo de trabalho era de natureza bastante permanente e estável. Nes ses grupos 'fixos' (chamados de 'turma firme') pode haver um grupo constante, cujos membros trabalham juntos regularmente para o mesmo 'gato' e, freqüentemente, no mesmo estabelecimen to por um ano ou mais. Em épocas de demanda máxima esse grupo aumenta através da incorporação de amigos e parentes":- (SAINT,

* Esta afirmação baseiamse especialmente nos trabalhos de SiL VA (1977) e MARTINEZ-ALIER (1977), sendo que o primeiro ana lisa uma "turma firme" que trabalhava já por 5 anos segui dos em uma mesma propriedade e com o mesmo turmeiro, inclú sive com a situação trabalhista regularizada. A segunda analisa o caso de uma turma que há dois anos trabalhava em local fixo, embora os trabalhadores não contassem com car teira assinada. 
1982:152).

$$
\text { Contudo, existem também os volantes que são }
$$

obrigados a se transferirem constantemente de empreiteiros e empregadores, procurando assegurar seus empregos durante todo o tempo, no que muitas vezes não são bem sucedidos. Na região da Alta Sorocabana, D'INCAO E MELLO (1975) constatou que somen te $15 \%$ dos bóias-frias estavam permanentemente empregados como tais, os demais passavam por fases de desemprego ou se emprega vam no meio urbano, em serviços de menor qualificação.

A instabilidade de trabalho e a inexistência de vínculos formais de emprego são dois fatores ligados entre si. Quanto mais intenso for o primeiro mais facilmente tenderá a ocorrer o segundo e vice-versa. A pergunta que se pode fazer é: a evolução do mercado de mão-de-obra volante se dá em dire ção ao aumento da instabilidade e informalidade das relações de trabalho ou em sentido contrário?

Para alguns autores, o primeiro caso é que se ria verificado. "Resultado do desenvolvimento, simultâneo ou sucessivo, das formas de apropriação da terra e dos níveis de acumulação do capital, esse processo implica não só na radical separação entre os trabalhadores e o meio de subsistência como também numa crescente instabilidade de emprego" (BRANT, 1975: 39: grifado na transcrição). "Em sua forma mais desenvolvida. e visível, os assalariados volantes servem ao capital simulta neamente na produção agrícola, na indústria de transformação, construção civil e serviços. Constituem uma categoria 'inter

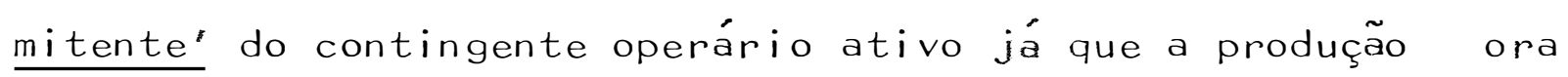
os repele, ora os atrai * Dependendo ainda fundamentalmente do emprego agrícola, estão submetidos a constantes períodos de 
desemprego cuja duração depende da diversidade das culturas e do desenvolvimento das atividades urbanas" (LANGE et alii 1982: 132, grifado na transcrição).

$$
\text { Já para GRAZIANO DA SILVA, contrariamente, }
$$

a tendência se daria no sentido de consolidação do bóia-fria permanente. - Assim, o autor afirma que "... esse tipo de tra balhador volante que tem uma relação de emprego intermitente. não é produto final, acabado, processo de proletarização do camponês. Essa é apenas uma forma transitória, que prevalece enquanto se organiza o mercado de trabalho urbano-rural de mão-de-obra não qualificada. A partir daí, as 'tumas firmes' de trabalhadores rurais volantes, bem como os operários' 'semiqualificados' (especialmente operadores de máquinas) passam a substituir essa relação de emprego intermitente que ameaça às vezes a própria reprodução do capital no campo, especialmente nos momentos cruciais de pico de serviço como na época das co Iheitas" (GRAZIANO DA SILVA, 1981:5, grifado na transcrição).

Pelo menos dois fatores têm importância na maior ou menor estabilidade de emprego dos volantes. Um é a própria. sazonalidade das tarefas agrícolas; à medida que as ta

* O autor considera como (a) bóia-fria permanente aquele que constitui praticamente um trabalhador efetivo da proprieda de agrícola, onde trabalha quase ou ininterruptamente po $\bar{r}$ um ou vários anos, em contraponto ao (b) bóia-fria eventual ou esporádico, consțituído de menores, mulheres e crianças que se empregam em épocas de maior necessidade de mão-deobra no meio rural, não fazendo parte regularmente da força de trabalho, e ao (c) bóia-fria temporário que alterna em pregos rurais e urbanos, personificando a unificação do men cado de trabalho da mão-de-obra não qualificada. 
refas agrícolas são mais dispersas dentro do ano e de curta du ração, ou seja, à medida que as necessidades de mão-de-obra por parte do empresário sejam mais descontínuas, a vinculação do volante tenderá a sermenor.

Entretanto, a inexistência de vínculos mais de finitivos da mão-de-obra com a empresa pode trazer problemas a sua organização (este seria o segundo fator). "Acontece ... que a relação de produção típica do capitalismo pressupõe não só uma força de trabalho 'livre', no duplo sentido de sem pro priedade e sem peias à sua mobilidade, mas a sua venda sistemá tica e contínua por ponderáveis períodos de tempo a uma mesma unidade de produção. Sendo o processo de produção capitalista uma sucessão de ciclos que se entrelaçam continuamente - donde se deriva o caráter permanente da empresa, que se distingue por isso mesmo do empreendimento - o fornecimento de força de trabalho tem que ser igualmente contínuo sob pena de interrom per aquele processo, retirando-lhe sua eficácia. É fácil vi sualizar a importância que o problema de continuidade da força de trabalho assume para o capital, imaginando o que ocorreria a uma fábrica que tivesse que recrutar diária ou mesmo semanal mente seus operários" (SINGER, 1977: " grifado na transcrição). Além disso, como o autor acentua, a reprodução "normal" da for ça de trabalho estaria comprometida com uma relação de emprego que se faz, desfaz e refaz em intervalos curtos e irregulares.

As afirmações de SINGER são importantes, mas me recem dois reparos. Em primeiro lugar, a produção agrícola apresenta certas especificidades que a distinguem da indus trial "pois" ".. com raríssimas exceções, os processos elemen tares na agricultura não podem ser dispostos em. linha, como um 
processo fabril. Eles podem ser dispostos apenas paralelamen te, todos começando, em cada lugar, na fase apropriada do ci clo climático anual" (GEORGESCU-ROEGEN, 1970). Além disso, a organização dos volantes pode se dar fora da empresa agrícola, seja através das firmas empreiteiras de mão-de-obra ou através das cooperativas de bóias-frias (BACCARIN et alii, 1984).

Em suma, a necessidade de maior controle e orga nização da força de trabalho agiria no sentido de éstimular maiores vínculos e estabilidade da mão-de-obra volante, ao pas so que a dispersão e curta duração das tarefas agrícolas agi ria no sentido contrário.

Independente do maior ou menor vínculo de empre go do bóia-fria, a literatura tem sido unânime em considerar suas condições de vida como bastante precárias, caracterizadas pelo baixo nível nutricional de sua alimentação, pelo elevado grau de analfabetismo; pelas moradias deficientes e por sérios problemas de saúde (FETAEG, 1977; FREITAS, 1977; OLIVEIRA \& OLIVEIRA, 1981).

As precárias condições vivenciadas pelo bóiafria provocam um estado de constante insatisfação com o "sta tus quo" e, em consequência, desejos prementes de melhores con dições de vida. Para D'INCAO E MELLO (1975) esta aspiração é de difícil viabilização, pois o bóia-fria tem a sua vida defi nida dentro de um campo de carência material e cultural, que tende a persistir através dos anos. Além disso, a própria na tureza do trabalho dos volantes traz algumas implicações que dificultam a união desses trabalhadores e; por conseguinte, diminuem o seu poder de pressão reivindicatória.

Assim, a autora destaca as dificuldades de con 
centração dos bóias-frias. "Eles só se concentram no período da colheita e, embora residam próximos um dos outros - exis tem bairros inteiros de 'bóias-frias' - não desenvolvem maio res contatos entre si, uma vez que se dispersam para trabalhar aqui e ali, nos demais períodos do ano" (D'INCAO E MELLo,1975: 138).

Também, a concorrência pelo trabalho aparece co mo grande obstáculo à união dos bóias-frias. "Preocupados com a garantia de trabalho, nos períodos em que não há colheita, eles assumem os valores do empregador e competem com os pró prios companheiros" (D'INCAO E MELLO, 1975:143).

E quais seriam as reivindicações básicas dos vo lantes? A literatura tem destacado duas ordens distintas de reivindicações: uma dirigida a melhores condições de trabalho (regularização trabalhista, emprego fixo e salário mais alto). e outra dirigida à posse da terra para plantar (D'INCAO E MEL LO, 1975; GRAZIANO DA SILVA, 1982).

Para D'INCAO E MELLO (1975); os trabalhadores que almejam trabalho fixo, especialmente nas cidades, são exproletários rurais que sofreram todo um processo de perda de sua identidade e da consciência de sua própria especialização, no decorrer de longos anos de experiências frustradas como par ceiros no meio rural. Já os que querem ser lavradores autôno mos são aqueles que passaram diretamente das condições de cam poneses no meio rural para a condição de bóia-fria.

GRAZIANO DA SILVA (1982) afirma que as reivindi cações por terra são maiores nas regiões onde o desenvolvimen to das forças produtivas na agricultura é menor, ou seja, em locais onde a proletarização da força de trabalho agrícola ain 
da não se consolidou. Também, os trabalhadores mais velhos tenderiam a querer voltar para as fazendas, enquanto os mais novos almejariam melhores condições de vida na cidade.

\subsection{Formação do Bóia-Fria}

Genericamente, a formação do bóia-fria tem sido explicada como resultante da expansão do capital à agropecuá ria brasileira, vinculada a fenômeno mais amplo que é o pró prio processo de industrialização brasileira (GONZALES \& BAS TOS 1982; LANGE et alii, 1982). "A transformação do escravo em proletário ... somente se desenvolveu na medida em que se desenvolveram as forças produtivas e as relações sociais de produção, no setor agrário e no conjunto do subsistema econômi co brasileiro. Em outras palavras, o surgimento do proletaria do rural, como categoria política fundamental da sociedade bra sileira, somente ocorreu na época em que se verificiou a hege monia da cidade sobre o campo, quando o setor industrial sú plantou o setor agrícola (econômica e políticamente) no contro le das estruturas de poder do país" (IANNI, 1976).

A expansão do capital à agropecuária brasileira passou por intenso crescimento, especialmente a partir de 1960 , fazendo com que a produção mercantil simples de mercadorias fosse perdendo importância em favor da produção mercantil capi talista,

*/ Este fato se relaciona à elevação dos preços das terras agrí colas, o que resulta na expulsão da "agricultura de subsís tência para fora dos limites dos Estados mais desenvolvidas tornando mais barato o pagamento de salário monetário do que a cessão da terra para que o trabalhador produza seus próprios alimentos dentro da propriedade" (KAGEYAMA, 1982: 11). 
sários agrícolas e ocorresse a substituição de antigas rela ções de trabalho (parceria, colonato, pequenos proprietários semi-assalariados) por novas relaçoes de trabalho, onde o assa lariamento monetário tendeu a assumir papel primordial. Estas transformações apresentaram,como conseqüencia, a liberação de parcela de mão-de-obra despojada dos meios de produção, grande parte expulsa em direção aos centros urbanos.

Alguns autores, IANN (1976b) e BRANT (1977) en tre outros, têm analisado as transformações pelas quais passou a agricultura paulista no presente século; especialmente no que se refere às alterações das relações de trabalho. O pri meiro utiliza como universo empírico a cidade de Sertãozinho, na Região de Ribeirão Preto e o segundo, o município de Assis na Alta Sorocabana. Ambos tomam, como tendência predominante nas alterações das relações de trabalho, a passagem do colono, vinculado à cultura cafeeira, ao trabalhador volante ou bóiafriax

Para BRANT (1977:48) este processo se acentua após 1940, sendo que "o surgimento do bóia-fria, diferentemen te de out as situações de desemprego rural, não resulta de mo do imediato de modificacões na estrutura fundiária (expropria ção de camponeses, etc) nem da aparição de excedentes popula cionais frente à escassez dos meios de subsistência (queda de produção agrícola, cataclismas, etc). O novo exército indus trial de reserva resulta de transformacões nas empresas agrope. cuárias capitalistas que se desembaraçam da sua mão-de-obra re sidente, sem que haja possibilidade de outras formas de empre go rural permanente para a maior parte dos trabalhadores" (Gri fado na transcrição). 
O contingente de colonos do café foi constituí do, em grande parte, por imigrantes, provenientes especialmen te da ltália. Vinham para o Brasil, porque em seu país de ori gem haviam sofrido processo de expropriação, passando de campo neses a proletários, sendo que a economia italiana não conse guia absorver totalmente estes trabahadores, gerando-se gran de número de desempregados e subempregados, o que representava grave problema social. A emigração destes trabalhadores para a América foi a "válvula de segurança" encontrada pela ltália e outros países europeus para evitar possíveis convulsões so ciais (SOUSA \& GEBARA, 1984).

Os italianos emigravam com a promessa de terem acesso fácil à posse da terra no país de destino. O que encon travam no Brasil, entretanto, era uma realidade totalmente di ferente, caracterizada pela alta concentração da posse da ter ra e pelas dificuldades de acesso à terra, impostas pela polí tica oficial, vinculada aos interesses dos cafeicultores. Aos latifundiários intercssava que os imigrantes permanecessem "li vres" dos meios de produção, para que pudessem trabalhar nas plantações de café.

Chegando ao Brasil, o italiano, após breve pas sagem pela Hospedaria dos imigrantes, era contratado pelos fa zendeiros do café, cultura que se expandia em direção a oeste paulista - região de escassa população na época - e que deman dava um número considerável de trabalhadores.

O contrato de colonato do imigrante com o pro prietário rural estipulava que a família do primeiro ficava responsável pelo cultivo de certo número de pés de café (conta do em milhares), realizando os tratos culturais e a colheita 
do produto. Em troca recebia una remunenaça em dinheiro, nor malmente ñào suficiente para a subsistência da família. Esta era complementada pela permissão de se plantar gêneros de sub sistência nas entrelinhas do café ou em áreas não aproveita das pela cultura principal. Também contava o colono com a in fraestrutura da fazenda, especialmente moradia, e tinha permis são de criar pequeno número de animais domésticos.

$$
\text { O sistema de colonato fazia com que o colono }
$$

cumprisse duas runções básicas. En primeiro lugar, servia co mo fonte de mão-de-obra à cultura do café, que se expandia por áreas onde não havia uma população prévia. A segunda função assumida pelo colono era que ele próprio ficava responsável pe la produção dos gêneros de subsistência de sua família, já que o café se expandia por áreas onde o mercado de alimentos não estava estabelecido.

"Como em outras regiões em que a agricultura co mercial implanta-se em terras virgens ou pouco exploradas, o capitalismo teve que transportar consigo os pressupostos do seu funcionamento . Se a infraestrutura necessária à própria produção e à sua comercialização desenvolvia-se na mesma pro porção em que se estendiam as plantações, as dificuidades maio res decorreriam da inexistência prévia de um mercado de traba Tho local, dado o escasso povoamento da área. Esse mercado de trabalho exigiria não só a presença, em número necessário, de trabahhadores mobilizáveis para as plantaçõos, como também a existência de um setor de produção dedicado a proporcionar-lhe os bens necessários à subsistência, ou um mercado de importa ção desses bens (o que ficaria mais caro)" (*..) "A solução mais frequente foi a de associar a instalaçäo dos trabalhado 
res, como moradores, nas próprias unidades produtivas com a in serção nos interstícios das grandes plantações comerciais, da produção de mantimentos" (BRANT, 1977:50).

Se o colonato teve seu desenvolvimento associa do à expansão do café, é a partir da crise cafeeira que o sís tema começa a perder importância.

IANNI (1976b), na análise do município de Ser tãozinho, revela que após a crise cafeeira decorrente de geada, secas e especialmente da crise econômica de 1929/30, a área cultivada com café declina, sendo substituída pela policultu ra, especialmente a cana-de-açúcar e o algodão. Alguns colo nos tornaram-se sitiantes pela compra de parte de latifúndios, outros transformaram-se em parceiros e arrendatários (diminui a concentração da propriedade e da posse da terra) e ainda outros foram proletarizados, desvinculando-se das fazendas de café e passando a habitar o meio urbano, sendo que parcela des ta população vem a constituir o contingente de bóias-frias.

Já em seu estudo BRANT (1977) considera a décá da de 40 como ponto de inflexção tanto de crescimento popula cional como de emprego agrícola na Região de Assis, quando fin da a etapa de penetração da agricultura capitalista e iniciase a etapa de desenvolvimento do capitalismo agrícola. A par tir de então, a região deixa de ser de imigração e passa a ser de emigração - acentua-se o deslocamento da população rural pa ra o meio urbano e a emigração para fora da região - sem que tenta ocorrido decadência das atividades econômicas, mas, ao contrário, na presença de um crescimento diversificado da pro dução agropecuária e agroindustrial. Isto revelaria o surgi mento de um excedente populacional relativo, cujo incremento 
se relacionaria aos rítmos de transformação da estrutura produ tiva, associando a diversificação da estrutura produtiva (sub stituição da agricultura por pecuária, caféicultura por cultu ras que exigem menos mão-de-obra) à concentração do capital agropecuário. Esta última se acentua na década de 50 , com mo dificações nas relações de produção pelo aumento da composição orgânica do capital e, em consequéncia, sendo permitida a uti lização mais intensiva da força de trabalho (emprego temporá rio para tarefas determinadas, mecanização e uso de insumos - her bicidas 0 autor também considera como causa explicativa do desaparecimento do colonato, o desvinculamento entre cultu ras permanentes e temporárias que levou à constituição de um cultivo comercial de alimentos (mercado de alimentos) capaz de abastecer a população não implicada em sua produção.

As trasnformações da agricultura regional, con forme relata BRANT (1977), levaram à intensificação do uso do trabalhador temporário, bóia-fria, sendo que nas empresas agrí colas (propriedades de 100-1000 ha) a quase totalidade da for ça de trabalho não qualificada foi excluída do emprego perma nente, sendo substituída por força mecânica (ou química, como é o caso dos herbicidas), ou empregada apenas temporariamente nos "picos" do processo produtivo.

"A proporção crescente do trabalho temporário em relação ao permanente revela dois aspectos da evolução da

* O emprego de herbicidas na agricultura brasileira, na verda de, é constatada mais recentemente, especialmente após $197 \overline{0}$. 
empresa agrícola: primeiro, a restrição das despesas com a re muneração da força de trabalho aos momentos do processo produ tivo em que ela se faz realmente necessária; segundo, a separa ção entre as tarefas qualificadas e não qualificadas. Ambos os aspectos estão ligados à transformação da agricultura em in dústria e à formação do exército industrial de reserva. Eles correspondem a um momento de desenvolvimento da agropecuária em que as determinações do mercado atingem simultaneamente os produtos e as forças produtivas, inclusive a força de trabalho" (BRANT, 1977:81).

o surgimento do bóia-fria se relaciona, portanto, com as transformações capitalistas ocorridas na agricultu ra brasileirarresponsáveis pela expulsão de uma parcela da po. pulação para a fronteira agrícola e de outra para o meio urba no. A sua persistência, como exército de reserva de mão-deobra, no meio urbano, mostra a incapacidade deste setor em ab sorver totalmente, ou grande parte, da mão-de-obra liberada pe la agricultura. Isto decorre do processo de industrializa ção brasileira ter se dado com a utilização de técnicas alta mente intensivas em capital criadas originalmente para as con dições de países desenvolvidos-e que não conseguiram apresen tar uma oferta de emprego compatível com o crescimento da popu lação urbana, ocasionando o desemprego urbano e a hipertrofia do setor de serviços (ÂNGELO, 1980).

Antes que se siga adiante, um comentário merece ser feito especialmente sobre a colocação de BRANT (1977) = Co mo já referido, o autor privilegia na análise das alterações nas relações de trabalho a passagem do colono ao bóia-fria. Outros autores acentuam que na formação do bóia-fria também té 
ve contribuição a expropriação de pequenos proprietários. Dos trabalhadores agrícolas do Estado de São Paulo, por exemplo, parcela considerável se constitui de migrantes, especialmente provenientes do Nordeste, onde, muitos deles, foram pequenos proprietários.

Formada a categoria de bóias-frias, despossuí dos dos meios de produção, moradores, embora não empregados, pelo menos de forma definitiva, no setor urbano, a utilização destes trabalhadores pela agricultura tende a se dar de forma sazonal. Isto porque a agricultura, por sua própria natureza, apresenta diferença entre o tempo de produção e o tempo de tra balho, ou seja, durante o ciclo de uma determinada cultura existe um tempo de trabalho e um de não-trabalho. Isto faz com que a demanda por mão-de-obra não seja a mesma durante. o ciclo da cultura, ocorrendo momentos de picos e momentos de retração na utilização da mão-de-obra agrícola. A existencia de um contingente de trabalhadores disponíveis nos centros ur banos possibilita aos empresários rurais a contratação da mãode-obra somente nos momentos em que ela se faz necessária.

o fato da utilização dos volantes se dar de for ma sazonal leva alguns autores, especialmente GRAZIANO DA SIL VA (1981, 1982), a considerar que o aumento da sazonalidade das tarefas agrícolas teve contribuição acentuada para o cres cimento do emprego de volantes na agricultura. E, entre os fá tores que estimulariam o aumento da sazonalidade, são destaca dos: o tipo de modernização da agricultura brasileira e a especialização das propriedades e regiões em determinados produtos agrícolas.

Quanto ao primeiro fator, a argumentação é a 
seguinte: a modernização da agricultura brasileira não se deu de maneira homogênea durante o ciclo de grande número de cultú ras. Enquanto que operações como o preparo do solo e plantio não apresentaram maiores dificuldades de serem mecanizadas, permaneceram alguns entraves de natureza técnico/econômica pa ra mecanizar as colheitas de culturas como o café, cana, laran ja, algodão e amendoim. Assim, reduziram-se significativamen te as necessidades de mão-de-obra naquelas fases das culturas, permanecendo nesta praticamente a mesma necessidade de mão-deobra anterior à modernização, ou mesmo a necessidade foi aumen tada nesta fase devido a ganhos de rendimento cultural, exigin do emprego de maior número de trabalhadores na colheita.

Dada ésta "heterogeneidade" de modernização no ciclo das principais culturas brasileiras, este fato estimula ria os empresários agrícolas a manterem em suas unidades produ tivas um pequeno número de trabalhadores, normalmente especia lizados, utilizados praticamente durante todo o ciclo produti vo, ao mesmo tempo que dispensariam o restante da mão-de-obra, que se transforma em volante e que, esporadicamente, nos momen tos de pico, seria recontratada para a realização das tarefas sazonais. GRAZIANO DA SILVA (1982:144) chega a dizer: além do volante ser um produto do desenvolvimento das forças capitalistas na agricultura, enquanto proletário rural ele é, ao mesmo tempo, resultado da insuficiência e da fraqueza desse desenvolvimento. De insuficiência do capital em submeter as forças da natureza do ponto de vista técnico; da fraqueza de generalizar essa subordinação, não apenas do ponto de vista formal, mas sobretudo de uma maneira real e ampla, revolucio nando a produção agrícola em todas as suas fases". 
O efeito da especialização de propriedades e re giões sobre a sazonalidade da mão-de-obra édescrito por KAGEYA MA (1982:11)"... conjugando-se duas ou mais atividades com ci clos de demanda de trabalho alternados se poderia garantir um patamar mais elevado do emprego permanente. No entanto, a ten dencia verificada no Brasil teve sentido oposto, de especiali zação das propriedades num ou noutro produto. Têm-se, hoje, as fazendas de laranja, as fazendas de gado, as fazendas de cana, etc., e, pior do que isso, houve uma especialização re gional das monoculturas, de forma que se têm também as regiões de cana, as regiões de soja, etc. A especialização regional veio agravar ainda mais a situação dos empregados temporários, que são obrigados a percorrer distâncias cada vez maiores para conseguir emprego durante todo o ano".

Mais adiante, quando se falar das técnicas em pregadas na cana-de-açúcar (ítem 3.3.1.), voltar-se-á a discu tir o papel da sazonalidade de mão-de-obra e de seus citados condicionantes (a modernização e a especialização) na formação do bóia-fria. Pode-se dizer, entretanto, que a especialização da área agrícola em determinados produtos não é exclusivo do Brasil, mas também se verifica em outros países onde o traba I ho temporário não assume grande importância. Também pode-se argumentar que a sazonalidade da necessidade de mão-de-obra nas culturas, como a cana-de-açúcar e o café, não é recente, mas já verificada em fases onde o bóia-fria era de somenos im portância na agricultura brasileira.

Por fim, pode-se comentar o papel da implanta ção do Estatuto do Trabalhador Rural (ETR), a partir de 1963, sobre as transformações das relações de trabalho na agricultú 
ra brasileira, especificamente, sobre o crescimento do número de bóias-frias. O ETR, que proporcionou uma série de direitos e garantias ao trabalhador rural, tais como salário mínimo, fé rias remuneradas, indenização em caso de dispensa etc., tem si do apresentado como catalizador do aumento da participação dos trabalhadores não-residentes ou volantes na agricultura (GRA ZIANO DA SILVA, 1982; KAGEYAMA, 1982). A dispensa dos traba Ihadores residentes e a contratação de trabalhadores volantes, agenciados pelos turmeiros e considerados como autônomos, deso brigariam o proprietário rural dos encargos trabalhistas além do que diminuiria o pagamento em espécie (moradia, lei te, lenha, etc.), tornando mais econômica a utilização dos bóias-frias (GONZALES \& BASTOS, 1982).

Outros autores dão maior importância ao papel ocupado pelo ETR. "Essa transformação provocada pelo poder do Estado (implantação do ETR) que ao fazê-lo criava certas condi ções gerais propícias ao desenvolvimento das formas capitalis tas incipientes já implantadas; gerando portanto novas rela ções de produção; emprestando um conteúdo próprio às formas já existentes e cuja existência se deve a condições de desenvolvi mento já anteriormente criadas no interior de relações de pro dução pré-existentes; esta transformação, dizíamos, teve o. efeito de produzir um imenso deslocamento espacial de popula

*/ Conforme discussão anterior, este ponto não é pacífico. Se na época da implantação do ETR esta afirmação podia ser con siderada como verdadeira, hoje em dia há toda uma jurisprü dencia firmada que garante ao volante os direitos trabalhis tas instituídos pelo ETR. Entretanto há ainda muitas em presas agrícolas que não legalizam a situação de seus trā balhadores volantes. 
ção, que é a forma pela qual a existência das novas relações se revela" (GNACCARINI, 1981:180).

Na verdade, a real participação do ETR nas mü danças ocorridas nas relações de trabalho da agricultura brasi leira ainda não foi süicientemente esclarecida e estudada, pelo menos até onde se conhece. Idéias de senso comum verbali zadas por proprietários rurais e até mesmo por trabalhadores atribuem toda a responsabilidade do crescimento do bóia-fria ao ETR* Entretanto, não se pode perder de vista que as modifi cações na população e no emprego, especialmente no Estado de São Paulo, iniciaram-se em período bem anterior à implantação do ETR. Se o Estatuto teve realmente alguma influência, foi a de acelerar estas transformações.

2.3. Conceito Síntese e Hipóteses

Adota-se o seguinte conceito básico do bóiafria: O bóia-fria é um trabalhador assalariado, despossuído dos meios de produção, morador dós centros urbanos e que cons titui um contingente de trabalhadores disponíveis tanto para empregos do setor rural (especialmente), quanto para empregos do setor urbano. No mais das vezes, os serviços que realiza não exigem maiores qualificações da mão-de-obra e não são con tínuos, daí decorrendo a instabilidade de emprego desta catego ria social.

A formação dos bóias-frias decorre do processo de transformações capitalistas da agricultura brasileira, que consolidou uma categoria de trabalhadores despojadas dos meios 
de produção e que passou a contar somente com a venda da força de trabalho para sobreviver. Especialmente para o Estado de São Paulo, a vertente principal na formação do bóia-fria não foi o processo de concentração fundiária (expropriação de cam ponéses etc.), mas sim as transformações nas empresas capita listas que resultaram na passagem do colono ao assalariado, especialmente temporário.

0 fato do trabalhador volante morar no setor ur bano implica na unificação do mercado de trabalho de toda a economia. Revela também a "urbanização" da agricultura, na me dida em que as empresas agrícolas tendem a usufruir da infraes trutura urbana (moradia, água, luz, etc.) fornecida pela socie dade como um todo e não ficarem como únicas responsáveis pelo seu fornecimento aos trabalhadores.

A característica a privilegiar no conceito do bóia-fria, que the confere certas especificidades em face, a outros segmentos do operariado, é a instabilidade de emprego. o bóia-fria é empregado intermitente em diversas propriedades e culturas e também no setor urbano em serviços não-qualifica dos. Para o empregador, o uso do bóia-fria significa redução dos custos, à medida que só emprega a mão-de-obra nos momen tos quando ela se mostra necessária.

A necessidade de melhor organização e controle da mão-de-obra por parte da empresa agrícola pode fazer com que ocorra aumento nos vínculos de emprego, diminuindo a insta bilidade de trabalho do bóia-fria.

Da instabilidade de emprego e dos baixos níveis salariais recebidos decorrem as precárias condições de vida 
dos bóias-frias. O caráter disperso de seu trabalho dificul ta a mobilização do bóia-fria como categoria social e diminui seu poder reivindicatório. A precariedade em que vive provoca no trabalhador desejos prementes de mudança em sua situação e caracteriza a categoria como um foco de constante tensão so cial. 


\section{3 - AS TRANSFORMAÇÕES NA AGRICULTURA E AS RELAÇÕES DE TRABALHO NO MUNICÍPIO DE JABOTICABAL}

A fundação do município de Jaboticabal data de 1828. Até por volta de 1880 a vida e a economia locais eram pouco desenvolvidas, sendo que "seus antigos habitantes oriun dos, em grande parte, da província de Minas, em vista da difi culdade de transporte e pela falta de boas estradas não cogita vam da lavoura de café e entregavam-se, exclusivamente, à cria ção de gado vacum e cavalar" (WHITAKER, 1978:17).

A agricultura praticamente se limitava à subsis tência, sendo que as pequenas roças existentes tinham a função de alimentar a esparsa população que vivia da pecuária extens va localizada em áreas mal exploradas. "É este aspecto despro vido, primitivo, com propriedades de divisas imprecisas, e com produção pouco vinculada ao mercado, que tinha a região antes 
de ser atiingida pelo café" (ZAMBON $1,1978: 64)$.

No último quartel do século passado, com a che gada da estrada de ferro ao município, o café começa a se de senvolver aceleradamente em Jaboticabal, como de resto em toda a Região de Ribeirão Preto. É a partir daí que a economia lo cal ganha novo alento, ampliando suas relações econômicas com o restante do país, bem como com o mercado internacional, atra vés da exportação do café.

O dinamismo da lavoura cafeeira, com sua grande necessidade de mão-de-obra,fazia com que a escassa população local se mostrasse insuficiente e estimulava a vinda de muitos imigrantes para a região, especialmente italianos. "Aproxima damente a metade da população em 1901, segundo publicação da época, era composta de imigrantes, predominando entre eles o italiano, que devido às crises no seu país de origem, não hesi tou em emigrar para o Brasil" (ZAMBONI, 1978:64).

O desenvolvimento da cultura cafeeira ora passa va por momentos de euforia, quando os preços internacionais se elevavam, ora passava por momentos de crises decorrentes de geadas (especialmente no ano de 1918), de secas e, principal mente, de quedas dos preços internacionais do produto. A cri se definitiva, que veio interromper o ciclo cafeeiro, ocorre em 1929/30 quando, devido a sérios problemas da economia mun dial, os preços do produto caíram vertiginosamente e as pers pectivas de venda dos seus estoques se mostravam reduzidas. Foi erradicado grande número de cafeeiros, sendo que em Ja botioabal, entre 1924 e 1944, a produção do café caiu em 85\% (ZAMBONI, 1978). 
Acompanhando a queda na área com café, verifi ca-se no município uma diversificação de cultivos, crescendo em importância culturas como o feijão, o milho, o arroz e, es pecialmente, o algodão que, de 1924 a 1944, aumenta a produção em $11.492 \%$ e propicia a iristalação de três firmas beneficiado ras do produto no município. Este período de agricultura di versificada que se estende da crise cafeeira até o início dos anos $50 \mathrm{ficou}$ conhecido como a "fase cerealista".

Além da diversificação de culturas, observada, de modo geral, em toda a Região de Ribeirão Preto, caracteriza a "fase cerealista" o deslocamento das atividades artesanais para as cidades e o início do uso industrial do solo urbano, caracterizando um processo de urbanização que se acentua conti nuamente daí em diante (SEP, 1978).

A fase cerealista não chegou a se consolidar plenamente e já a partir de 1950, começa a se caracterizar uma nova fase na agricultura do município, associada ao rápido crescimento da cultura da cana-de-açúcar. "Esta estrutura de produção - fase cerealista - não se modificou muito até a déca da de 50, quando de forma mais significativa, começou a se im plantar no município a cultura da cana-de-açúcar. Era a volta de um produto tropical de exportação a cobrir o solo do municí pio e a tornar a concentrar a propriedade agrícola, que

no pós-crise, tendeu à desconcentração" (ZAMBON\}, 1978:65).

o período básico analisado neste capítulo refe re-se ao que ocorrelide 1940 em diante. Isto porque parece ser a partir de então que se acentuam as mudanças na população e no emprego no setor agrícola paulista (BRANT; 1977), e também por que a análise deste período permite uma visão abrangente da 
"fase canavieira" que começa a se consolidar a partir de 1950. Uma observação merece ser feita antes que se in icie a análise propriamente dita. Após 1940, ocorreram dois desmembramentos no município "de Jaboticabal, o primeiro na dé cada de 40, quando f̃oi desmembrado o município de Taiúva e o segundo na década de 50, com a saída do município de Taiaçu.

Diante disso, havia duas opções para a análise dos dados dos Censos Agropecuários: uma, a de considerar a so ma das áreas dos três municípios; outra, de somente levar em conta a área de Jaboticabal, tomando-se o cuidado da análise ser realizada em termos de números relativos e não absolutos. Esta última opção foi a adotada, mesmo porque, embora inicialmente houvesse certa homogeneidade entre os muni cípios, após 1950 Jaboticabal tendeu a se tornar um "município canavieiro", enquanto os outros dois tenderam a expandir as áreas plantadas com laranja. Na tentativa de privilegiar essa tendência de especialização municipal, a análise é feita sem somar as áreas dos municípios. De qualquer forma, sempre que necessário, os dados censitários de Taiuva e Taiaçu são consi derados na análise.

3.1. Utilização da Área Agrícola de Jaboticabal

Os dados apresentados no Quadro I revelam que, em 1940, - a ocupação do município de Jaboticabal já estava con solidada, sendo que mais de $90 \%$ da área dos estabelecimentos agropecuários já eram explorados economiciamente com atividades agropecuárias. A área de lavouras representava $45,4 \%$ da área 


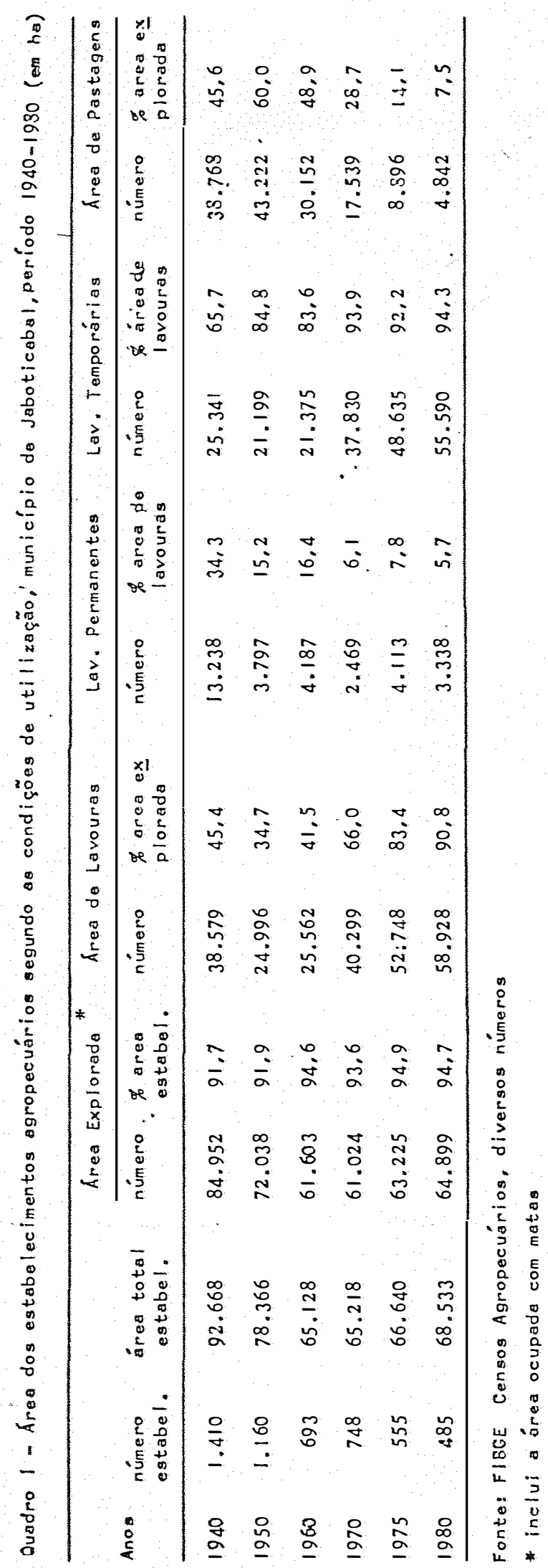


explorada, enquanto a pecuária ocupava $45,6 \%$ desta mesma área. Durante a década de 40 , a área de lavouras per deu importância relativa (de $45,4 \%$ para $34,7 \%$ da área explora da) em favor da área de pastagens, que aumentou sua participa ção de $45,6 \%$ para $60,0 \%$ da área explorada. Isto se associa, como se verá adiante, à queda da cultura cafeeira, que foi in i cialmente substituída pela policultura e pela pecuária. "Uma vez que a pecuária utiliza, normalmente, menor quantidade de mão-de-obra por hectare do que as atividades agrícolas, este crescimento da importância da pecuária acentuou o processo de migração rural-urbana.

Após 1950, o crescimento da área de pastagens é interrompido e a área de lávouras expande-se acentuadamente, especialmente após 1960, até atingir 90,8\% da área explorada em 1980. A área de pastagens, ao contrário, se reduz, passan do a ocupar somente $7,5 \%$ da área explorada em 1980. Portanto, após 1950, caracteriza-se uma redução da atividade pecuária e consolidação da atividade agrícola.

A evolução da área de lavouras deu-se com uma importante alteração na composição do produto agrícola, qual seja, a perda de importância das lavouras permanentes (reduzi ram sua participação de $34,3 \%$ para $5,7 \%$ da área de lavouras, entre 40 e 80) e o crescimento das lavouras temporárias (cres cimento de $65,7 \%$ para $94,3 \%$, entre 40 e 80 ).

Conforme pode ser visto no Quadro 2, a perda de importância das lavouras permanentes associa-se à queda da área ocupada pela cultura cafeeira. Enquanto que em 1937/38 


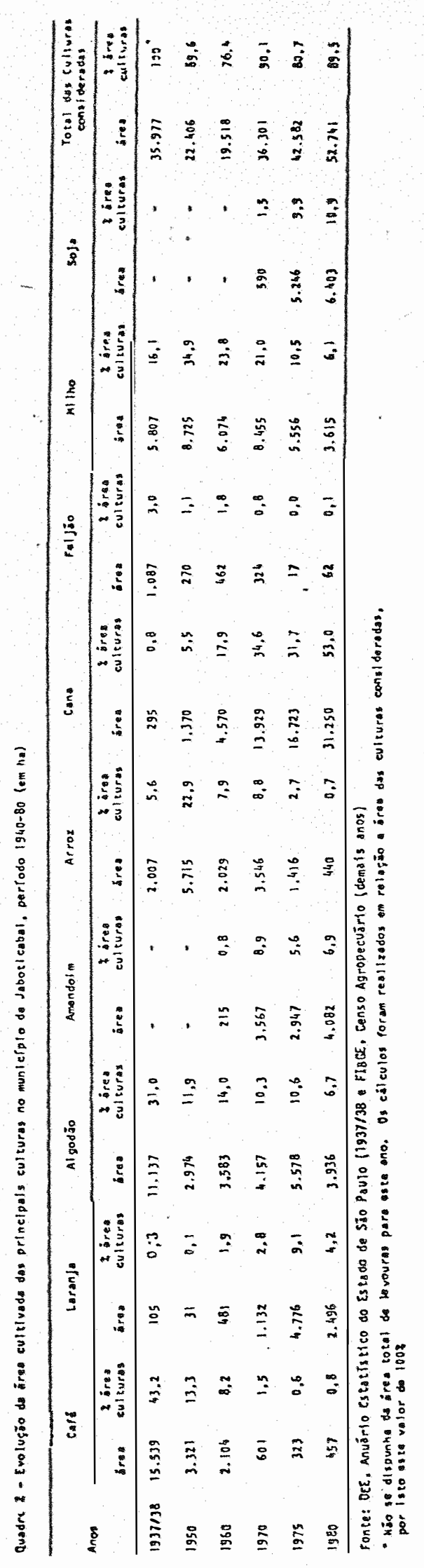


o café ocupava $43,2 \%$ da área com as culturas consideradas-" em 1980 só restavam 457 ha da cultura, representando apenas 0,8\% da área com lavouras no município. Uma informação complemen tar a estes dados é que em 1920 o café representava $63,6 \%$ da área cultivada no município de Jaboticabal. o declínio do ca fé na região tem seu início, provavelmente, na crise de 1929/ 30, caindo a importância da cultura acentuadamente a partir de então .

Em 1937/38, após café, despontavam as cultu ras do algodão, com $31,0 \%$ da área das culturas consideradas e o milho com 16,1\%. 0 arroz e o feijão tinham certa importân cia com $5,6 \%$ e $3,0 \%$ respectivamente, da área das culturas con sideradas. A cana, com 295 ha plantados, tinha participação bastante reduzida na ocupação da área agrícola do município.

A composição da produção agrícola alterou-se bastante no período analisado. Os cultivos do café, arroz e feijão tornaram-se praticamente insignificantes no município. As culturas do algodão e do mi liho ainda mantém certa importân cia na agricultura local, embora nos últimos 5 anos analisados para a primeira e nos úlzimos 10 para a segunda, esta importân cia tenha se reduzido. A cultura da laranja, ainda que tenha alcançado 9,1\% da área de lavouras em 1975, vem caindo a par

*) O Censo de 1940 traz somente a área total com lavouras, não especificando a área de cada cultura. Por isto, utilizouse informações do Anuário Estatístico de 1937/38 que forne cem as áreas das principais culturas agrícolas, mas não a área total de lavouras: A participação do café neste ano foi calculada em relação somente às 9 culturas consideradas e não à área total de lavouras. Assim, a participação do, café, bem como das demais culturas na área de lavoura, está superestimada para este ano. 
tir de então, não se firmando como uma das principais culturas locais. E, no período, duas novas culturas despontaram, ga nhando importância no município, o amendoim após 1950 e a soja após 1960.

Mas - o fato mais importante a ser destacado no Quadro 2 é o crescimento da participação da área de cana. De 0,8\% em 1937/38, a cultura salta para 53,0\% da área de lavoura em 1980, sendo que a tendência do crescimento, ao que tudo in dica, se manteve daí para diante. Chama a atenção o intenso crescimento da cultura de 1975 a 80, quando passa de 16.723 ha para 31.250 ha $(87 \%$ de aumento), fato esse diretamente associa do aos incentivos provenientes do Proálcool.

o crescimento da área de cana se relaciona com o aumento da capacidade da agroindústria sucro-alcooleira na região. A evolução da produção de açúcar e álcool das ․ duas usinas do município (Santa Adélia e São Carlos) é apresentada no Quadro 3. Observa-se que tanto a produção de açúcar quanto a de álcool cresceu acentuadamente, sendo que este, nos últi mos 8 anos $(75$ a 83$)$, mais que decuplicou sua produção.

Atualmente, além das duas usinas de açúcar e álcool já citadas, existem no município uma destilaria autôno ma de álcool e 2 aguardenteiras.

A tendência observada no município de Jabotica bal é, portanto, de especialização na cultura de cana, que passa a ocupar $45,6 \%$ da área dos estabelecimentos e mais da me tade da área de lavouras em 1980 (FIBGE, 1980). As culturas que vêm a seguir, a soja $(10,9 \%$ da área de lavouras) e o amendoim $(6,9 \%)$, "convivem" bem com a cana, pois sendo leguminosas e de ciclo curto, são normalmente plantadas nas áreas de renova 
ção dos canaviais.

Quadro 3 - Produção de açúcar e álcool no período 1950-83, no municipio de Jaboticabal

\begin{tabular}{lcc}
\hline Anos & Açúcar (sacos) & Álcool (litros) \\
\hline 1950 & 39.240 & 3.650 \\
1960 & 213.451 & - \\
1970 & 511.506 & 6.516 .000 \\
1975 & 1.110 .640 & 11.496 .840 \\
1980 & 2.017 .060 & 74.740 .000 \\
1983 & 2.220 .360 & $121.068 .000^{*}$
\end{tabular}

Fonte dos dados básicos: IAA, Boletim de Safras, diversos núme ros

* Inclui a produção de uma nova destilaria instalada no municí pio após 1980.

E não foi só a agricultura do município como um todo que tendeu a se especializar; as unidades produtivas apre sentaram a mesma tendência. Se há 40 anos atrás era comum o cultivo associado da cultura do café com arroz, milho e fei jão, hoje a cana é cultivada isoladamente, somente permitindo o cultivo de soja e amendoim nas áreas de reforma. A tendên cia de especialização das unidades produtivas fica bem eviden ciada no Quadro 4, que mostra a participação de cada cultura no número total de estabelecimentos no município.

Em 1940, várias culturas tinham importância em vários estabelecimentos - o café era plantado em $43,2 \%$ deles, o algòdão em 62,3\%, o arroz em 68,7\%, o feijão em 35,7\% milho em 76,5\%. Em 1980, somente o milho era plantado em um 


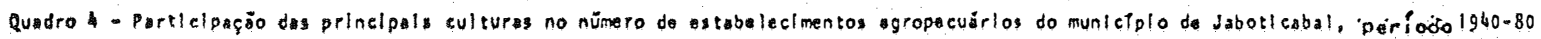

\begin{tabular}{|c|c|c|c|c|c|c|c|c|c|c|c|c|c|c|c|c|c|c|}
\hline \multirow{2}{*}{ Anos. } & \multicolumn{2}{|c|}{$\begin{array}{l}\text { Extobelecl frentos } \\
\text { com cofê }\end{array}$} & \multicolumn{2}{|c|}{$\begin{array}{c}\text { Estobelecel mantos } \\
\text { com laranja }\end{array}$} & \multicolumn{2}{|c|}{$\begin{array}{l}\text { Estabelecimentos } \\
\text { com olgodáo }\end{array}$} & \multicolumn{2}{|c|}{$\begin{array}{l}\text { Escabelecimentos } \\
\text { com amendoin }\end{array}$} & \multicolumn{2}{|c|}{$\begin{array}{l}\text { Estabelectmentos } \\
\text { com arroz }\end{array}$} & \multicolumn{2}{|c|}{$\begin{array}{l}\text { Estabeleclmentos } \\
\text { com cand }\end{array}$} & \multicolumn{2}{|c|}{$\begin{array}{c}\text { Estrobolecimentos } \\
\text { com follajo }\end{array}$} & \multicolumn{2}{|c|}{$\begin{array}{l}\text { Es tabaleclimentos } \\
\text { com dollho }\end{array}$} & \multicolumn{2}{|c|}{$\begin{array}{c}\text { Estabeifacimentos } \\
\text { com } 10\} \text {. }\end{array}$} \\
\hline & nümero & $\begin{array}{l}2 \text { no } \\
\text { estabst. }\end{array}$ & nüne ro & $\begin{array}{l}4 \text { n? } \\
8 \text { stabel. }\end{array}$ & nünero & $\begin{array}{c}n q \\
\text { es tabol. }\end{array}$ & nüra ro & 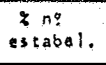 & nüme ro & $\begin{array}{c}q \text { nq } \\
\text { estabel. }\end{array}$ & nüme ro & 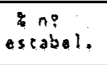 & nümero & $\begin{array}{c}2 n ! \\
\text { estabol. }\end{array}$ & nümero & $\begin{array}{l}i n: \\
\text { esrabel. }\end{array}$ & ninero & $\begin{array}{l}\text { ine } \\
\text { ostatel. }\end{array}$ \\
\hline 1940 & 609 & 43,2 & 244 & 17,3 & 879 & 62,3 & - & - & 968 & 68,7 & 20 & 1.4 & 503 & 35.7 & 1.078 & 76.5 & - & - \\
\hline 1950 & 319 & 27.5 & 239 & 20.6 & 390 & 33.6 &. & : & 905 & 78.0 & 95 & 8.2 & 215 & 18.5 & 1.074 & $92,6$. & 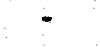 & - \\
\hline 1960 & 285 & 41.3 & 80 & 11,5 & 299 & 43,1 & $4 !$ & 5.9 & 469 & 67.7 & 116 & 16.7 & 215 & 31,0 & $\quad 524$ & 75,6 & 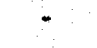 & $*$ \\
\hline 1978 & 123 & 16.4 & 95 & $: 2,7$ & 249 & 33.3 & 306 & 40.9 & 403 & 53,9 & 119 & 15.9 & 51 & 6,8 & 486 & 65.0 & 13 & 1.7 \\
\hline 1975 & 28 & 14,1 & 123 & 22,2 & 213 & 38.4 & 167 & 30.1 & 216 & 38,9 & 71 & 13,8 & 9 & 1.6 & 287. & 51,7 & 100 & 18.0 \\
\hline 1980 & 80 & 16,5 & 94 & 19.4 & 120 & 24,7 & 104 & 21.4 & 133 & 27,4 & 133 & 27.4 & 11 & 2.3 & 206 & 42,5 & 135 & 27.8 \\
\hline
\end{tabular}

Fonzen Flble. Cansos Agropacuärlos, dlversos nümaros 
grande número de estabelecimentos $(42,5 \%)$, as demais culturas eram plantadas por menos de $30 \%$ dos estabelecimentos, inclusi ve a cana, a soja e o amendoim.

É interessante observar que no caso da cana-deaçúcar, enquanto a 'cultura ocupava, em 1980, 45,6\% da área dos estabelecimentos, somente $27,4 \%$ do número total dos estabeleci mentos cultivavam este produto, o que indica que a área média cultivada com esta cultura tende a ser maior que para as de mais. Aliás, para todas as outras culturas consideradas, o inverso se verificava, ou seja, a participação na área era me nor que a participação no número de estabelecimentos.

Uma última observação a fazer nesta seção é que, enquanto Jabóticabal tendeu a se especializar na produção de cana, os municípios de Taiúva e Taiaçu. (desmembrados de Jaboti cabal), próximos às agroindústrias de suco, tenderam a se espe cializar na cultura da laranja. Em 1980, Taiúva apresentava $53,6 \%$ da área com lavouras ocupadas com Iaranja e Taiaçu 44,5\% (FIBGE, 1980).

3.2. A Distribuição da Posse e Propriedade da Terra no Mu nicípio de Jaboticabal

As análises conhecidas sobre a atual região ca navieira da DIRA de Ribeirão Preto consideram dois importantes momentos na história de sua estrutura agrária: o primeiro ca racterizado por um movimento de desconcentração da propriedade (loteamento de latifúndios) e da posse da terra (aumento do nú mero de parceiros e arrendatários) que passa a ocorrer após a 
crise cafeeira de 1929/30 e, o segundo, quando se verifica um movimento de reconcentração da posse e propriedade da terra, que se associa à expansão acelerada da cultura da cana-de-açúcar após 1950 (GEBARA, 1976;. IANNI, 1976b; ZAMBONI, 1979).

Com a crise cafeeira, muitos empresários rurais, premidos por dívidas junto ao sistema bancário e sob a perspec tiva de que os preços do café não se recuperariam de imediato no mercado internacional, vieram a lotear áreas de suas fazen das, ou cederam suas terras em parceria para cultivo de outros produtos, especialmente algodão. ZAMBONI (1979) destaca o pa pel da Companhia de Agricultura, Imigração e Colonização(CA/C) no loteamento de latifúndios da região, após a crise do café em 1929/30. Foram loteados, por exemplo, a Fazenda São Marti nho que abrangia os atuais municípios de Barrinha e Pradópolis e a Fazenda Dumont, no atual município de Dumont. Especifica mente no município de Jaboticabal a CAIC loteou cerca de 3.000 ha de terras.

Com a expansão da área plantada com cana-de-açú car, a tendência se alterou verificando-se a reconcentração da posse da terra na região, devido especialmente às economias de escala existentes na cultura e também às pressões dos usinei ros para controlar diretamente a maior parte da matéria-prima que suas indústrias necessitam para produção do açúcar e álco ol (GEBARA, 1976).

Com dados dos Censos Agropecuários pode-se veri ficar a evolução da distribuição da posse da terra no municí pio de Jaboticabal após 1940, período coincidente basicamente com a "fase canavieira". No Quadro, 5 , em suas duas últimas co lunas, observa-se que em todo período analisado (1940-80) a 


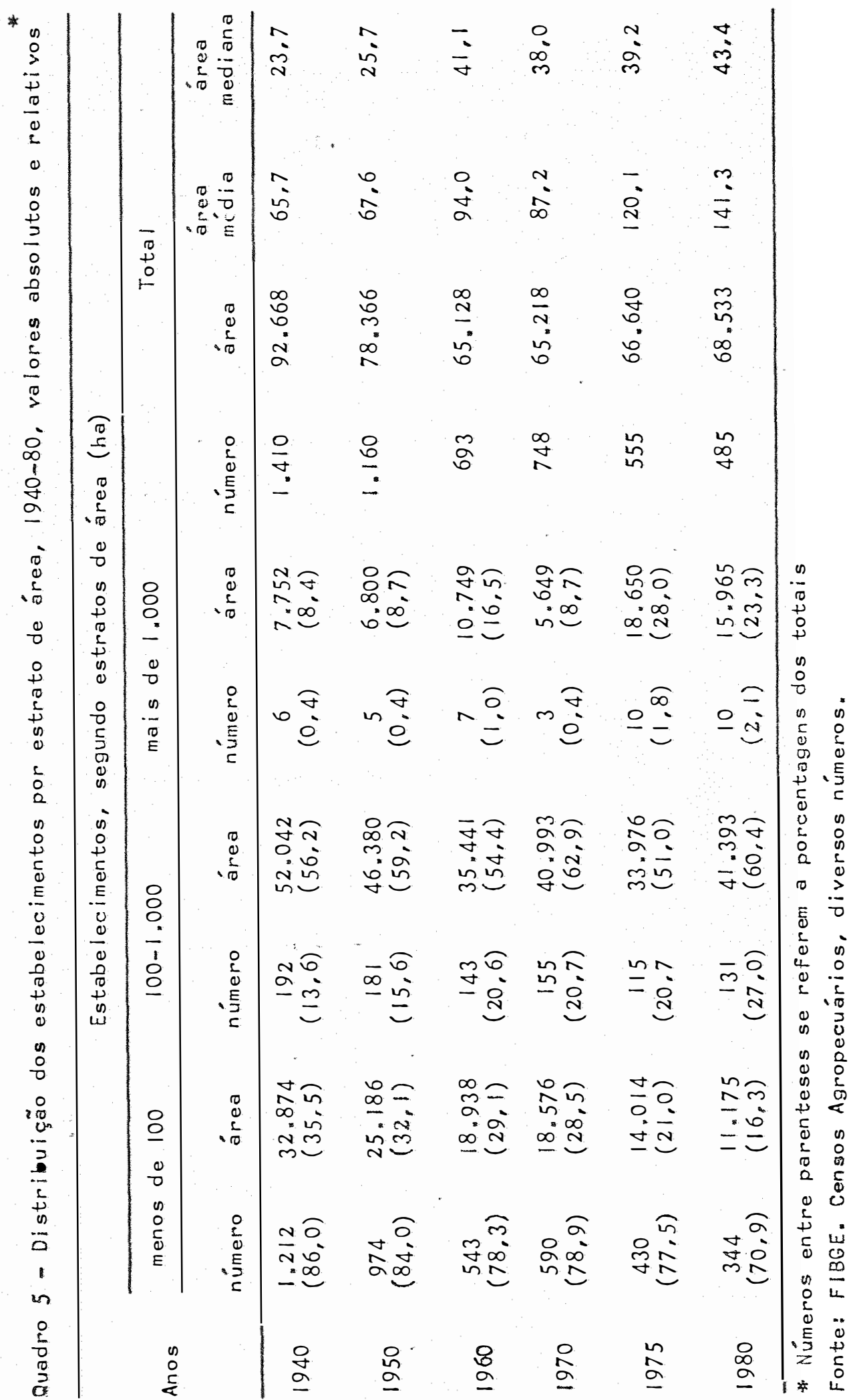


se mostrou maior que a área mediana, indicando assimetria na distribuição da área dos estabelecimentos em favor das maiores unidades produtivas.

Além disso, a área média dos estabelecimentos apresentou tendêncía de crescimento (com o ano de 1960 destoan do), tendo passado de 65,7 ha em 1940 para 141,3 ha em 1980*-" Chama a atenção o salto ocorrido na década de 70 , quando a área média passa de 87,2 ha para 141,3 ha, o que se relaciona à expansão intensiva da área de cana-de-açúcar no período.

O que pode-se considerar, portanto, é que na "fase canavieira" ocorre consolidação das maiores unidades pro dutivas. Isto pode ser facilmente visualizado no Quadro 5, on de se observa que no período analisado, os estabelecimentos me nores que 100 ha tenderam a diminuir sua participação relativa tanto na área quanto no número de estabelecimentos, enquanto que as unidades produtivas maiores que 100 ha apresentaram ten dência inversa. Este fenômeno se acentua na década de 70 , es pecialmente devido ao crescimento dos estabelecimentos maiores que 1.000 ha, que passam de menos de $10 \%$ da ocupação da área agrícola para mais de $20 \%$.

Em 1980, os estabelecimentos menores que 100 ha representavam $70,9 \%$ do número de estabelecimentos e 16,3\% da área agrícola. Já os estabelecimentos maiores que 100 ha, em bora representassem apenas $29,1 \%$ do número de estabelecimentos,

* Até 1960 esta evolução é afetada pelos desmembramentos dos municípios de Taiúva e Taiaçu, que apresentam - estrutura agrária caracterizada até os dias atuais pela grande parti cipação da pequena unidade produtiva.

*/De 1970 a 1975 o aumento da área média dos estabelecimen tos em parte se deve à mudança de conceito do estabelec $\bar{i}$ mento entre os Censos, o que não invalida a afirmação ac $\bar{i}$ ma. 
área média sempre ocupavam $83,7 \%$ da área agrícola do município. Os números revelam a distribuição desigual da posse da terra em Jaboticabal, com as grandes propriedades pro dutoras de cana controlando a maior parte da área agrícola lo cal. E este controle na verdade não é mostrado em sua totali dade nos dados censitários, pois como afirma RAMOS (1982), as usinas dissimulam a real posse da terra, colocando as unidades produtivas em nome de parentes dos proprietários.

\subsection{A Técnica na Agricultura de Jaboticabal}

No período analisado, profundas mudanças ocorre ram na técnica agrícola utilizada na agricultura do município de Jaboticabal. Pelo Quadro 6, percebe-se a evolução do tipo de força empregada nos serviços dos estabelecimentos a partir de 1950 (o Censo de 1940 não fornece esta informação). Em $1950,63,5 \%$ dos estabelecimentos usavam tração animal, 33,9\% não utilizavam nenhum tipo de tração, empregando somente a for ça de trabaltho humaña, 2, 4\% uti li zavam tração animal-mecânica e somente $0,2 \%$ dos estabelecimentos empregavam exclusivamente tração mecânica. A evolução verificada no tipo de tração em pregada na agricultura do município apresenta uma tendencia ní tida, qual seja, a diminuição da importância dos estabelecimen tos que utilizavam tração animal ou exclusivamente força de trabalho humana em relação aos estabelecimentos que utilizavam tração mecânica. Em 1980, 90,7\% dos estabelecimentos utiliza vam tração mecânica, sendo 71,5\% exclusivamente e 19,2\% em com binação com tração animal. 


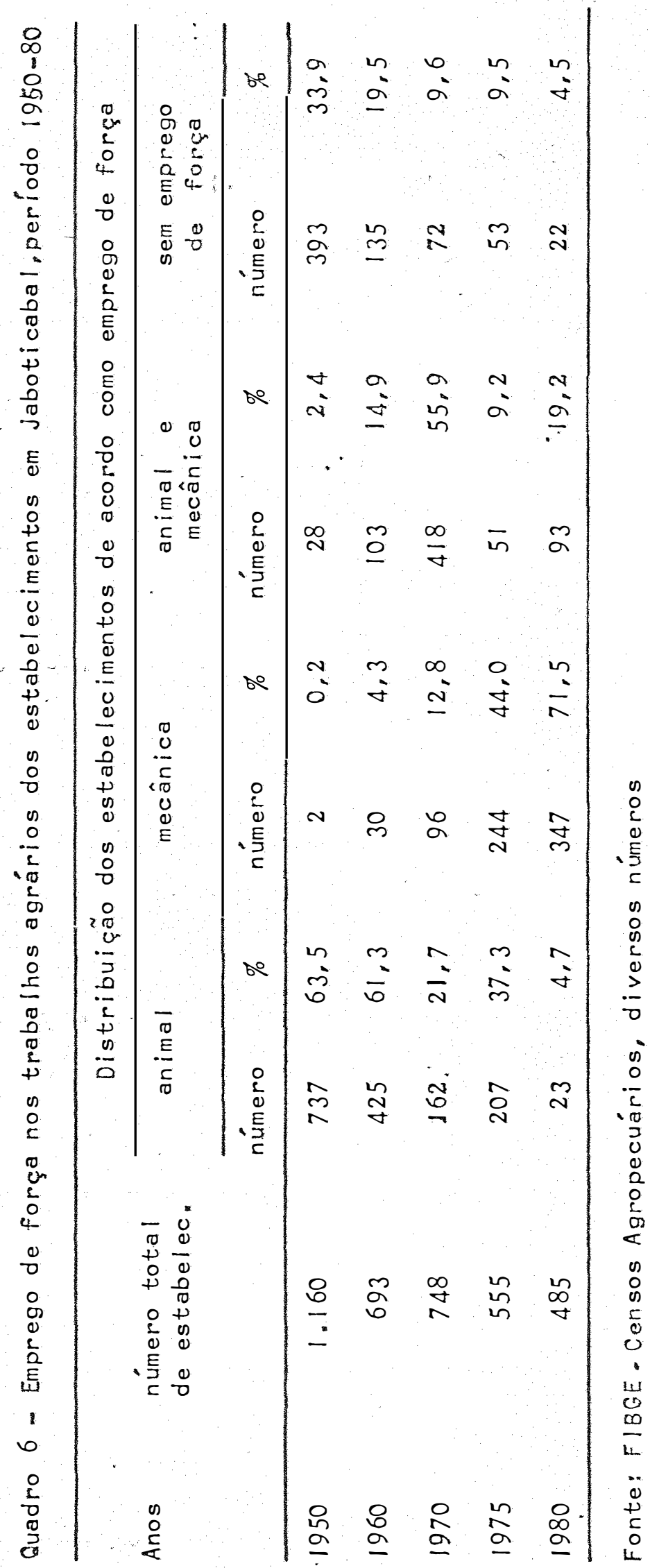


A alteração no tipo de força utilizada na agricultura está associada ao crescimento da utilização de tra tores agrícolas no município como pode ser visto no Quadro 7 . Em 1940 havia 0,1 trator $/ 100,0$ ha e somente $0,7 \%$ dos estabeleci mentos utilizavam-se de tratores. 0 crescimento do rúmero de tratores se acentuou, especialmente após 1950 e no fim do pe ríodo existiam 15 tratores/1000 ha e 63,3\% dos estabelecimen tos usavam esta máquina.

Quanto aos arados, os dados do Quadro 7 revelam a ocorrencicia de considerável mudança qualitativa no período. Os arados de aiveca, normalmente utilizados em conjunto com a tração animal, diminuiram sua importância, enquanto crescia a participação dos arados de disco, associados à tração mecânica. De 1975 a 80 cai um pouco a importância dos arados de disco, provavelmente devido à alteração no preparo de solo observado na cultura da cana-de-açúcar, que tendeu a substituir o arado pela utilização de pesadas grades puxadas por tratores de gran de potência.

Acompanhando a utilização das técnicas mecâni cas; o uso de técnicas químico-biológicas apresentou a mesma tendencia de crescimento na agricultura do município. A análi se fica prejudicada neste ponto, pois os dados só se encontram disponíveis a partir de 1960, os quais se encontram no Quadro 8. Os números revelam o crescimento da utilização da prática de adubação, tendo-se elevado de $72,6 \%$ para $94,2 \%$ a porcenta gem de estabelecimentos que realizavam qualquer tipo de aduba ção, entre. 1960 e 80 . Este crescimento do número de estabele cimentos que realizavam adubação foi acompanhado de aumentos da importância da adubação química, em detrimento da orgânica. 


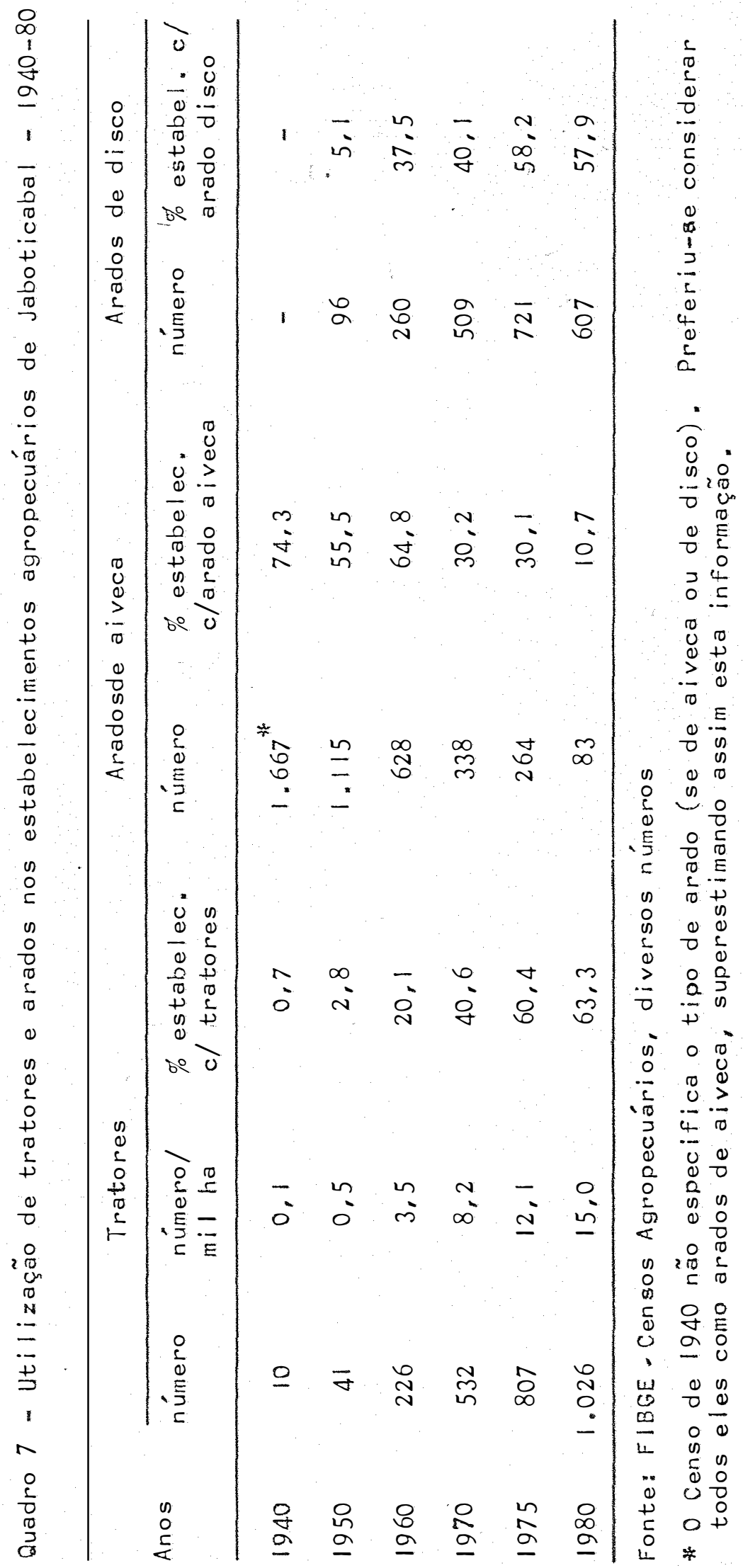


Em 1960, 34,9\% dos estabelecimentos usavam adubação química, $25,7 \%$ químico-orgânica e $12,0 \%$ orgânica. O primeiro valor ele vou-se para 66,6\% em 1980, o segundo caiu até 1975 e se elevou a partir daí, atingindo $24,5 \%$ em 1980 e o terceiro caiu até atingir $3,1 \%$ no final do período. A elevação da porcentagem dos estabelecimentos que realizavam adubação químico-orgânica nos últimos 5 anos da análise (1975-80) novamente se deve a mu danças ocorridas na cultura da cana-de-açúcar, pois nos últi mos anos a vinhaça (resíduo da produção do açúcar e álcool) vem sendo utilizada como adubo orgânico, não sendo despejada totalmente nos cursos d'água, mesmo porque esta ação passou a sofrer maior fiscalização.

Quadro 8 - Percentual de utilização de fertilizantes e calcá reo nos estabelecimentos agropecuários de Jaboticā bal - 1960-80

\begin{tabular}{|c|c|c|c|c|c|c|}
\hline \multirow[b]{2}{*}{ Anos } & \multicolumn{3}{|c|}{ \% Estabelecimentos que } & \multirow{2}{*}{$\frac{\text { e Realizam }}{\text { orgânica }}$} & \multirow{2}{*}{$\begin{array}{l}\text { Adubação } \\
\text { química } \\
\text { orgânica }\end{array}$} & \multirow{2}{*}{$\begin{array}{l}\% \text { estabel. } \\
\text { que realizam } \\
\text { calagem }\end{array}$} \\
\hline & de & $\begin{array}{l}\text { qual quer } \\
\text { tipo }\end{array}$ & química & & & \\
\hline 1960 & & 72,6 & 34,9 & 12,0 & 25,7 & 4,0 \\
\hline 1970 & & 86,0 & 65,0 & 10,1 & 24,9 & 33,8 \\
\hline 1975 & & 88,6 & 73,7 & 3,4 & 11,5 & 53,7 \\
\hline 1980 & & 94,2 & 66,6 & 3,1 & 24,5 & 59,4 \\
\hline
\end{tabular}

Fonte: FIBGE = Censos Agropecuários, diversos números

A prática de calagem também se generalizou, au mentando de 4,0\% para 59,4\% a porcentagem de estabelecimentos que realizavam esta prática entre 1960 e 1980, conforme o Qua dro 8 . 
A utilização intensificada de técnicas químicobiológicas contribui para aumento do rendimento cultural das culturas do município, especialmente do amendoim, cana, milho, algodão e soja. No caso daccana, a evolução foi a seguinte: 9 toneladas por hectare em 1940 , $46 \mathrm{t} / \mathrm{ha} \mathrm{em} 50$, $50 \mathrm{t}$ /ha em 60 , 57 tha em 70 e 78 t/ha em 1980 (FIBGE, diversos anos).

O aumento das inversões em técnicas mecânicas (tratores, arado, etc.) e técnicas químico-biológicas (ferti lizantes, defensivos, sementes, etc ) resultou em alteraçöes na composição do capital empregado na agricultura do município, perdendo importância a participação dos salários agrícolas. Assim, enquanto que em 1940 os salários representavam cerca de 75\% das despesas dos estabelecimentos, em 1980 este valor ha via se reduzido para aproximadamente $25 \%$. Ao mesmo tempo, as despesas com fertilizantes, defensivos, sementes, etc., passa ram, no mesmo período, de cerca de $8 \%$ das despesas totais para próximo a $27 \%$ (F|BGE, diversos anos).

Portanto, as transformações ocorridas na técni ca empregada na agricultura do município levaram a um aumento da participação do capital constante e diminuição da importân cia relativa do capital variável. A produtividade bruta do trabalho aumentou, já porque o crescimento do emprégo de máqui nas diminuiu a necessidade de trabalhadores por hectare, já porque a elevação do uso de técnicas químico-biológicas e al gumas mecânicas (irrigação, aração mais profunda, etc*) fez com que crescesse o rendimento por hectare das principais cul turas do município. 


\subsubsection{Técnicas Usadas na Cana-de-Açúcar}

Dada a importância que a cultura da cana-de-açú car assume no município de Jaboticabal, resolveu-se abrir este sub-item procurando caracterizarmais pormenorizadamente a evolução técnica desta cultura, principalmente em sua colhei ta, sendo utilizadas especialmente informações obtidas de en trevistas realizadas com proprietários rurais e trabalhadores do município.

A cultura da cana-de-açúcar caracteriza-se por apresentar em seu ciclo duas fases distintas no que se refere à utilização da mão-de-obra; uma delas a safra, onde a necessi dade de mão-de-obra se mostra consideravelmente maior que na outra fase, a entressafra. Nesta se realizam operações como o preparo do solo, plantio e tratos culturais que, de maneira ge ral, são feitos com utilização intensa de mecanização Já na safra a mecanização é menor, com a operação do corte de cana sendo realizada, na grande maioria das vezes, de forma manual. Isto pode sugerir que, ao longo dos anos, a modernização do cultivo da cana-de-açúcar foi parcial, tendo ocorrido incidên cia efetiva de progresso técnico e ganho na produtividade ape nas na fase da entressafra e não durante a safra. Assim, en quanto na primeira fase a necessidade de mão-de-obra diminui ria, na segunda, a necessidade de mão-de-obra se manteria ou mesmo seria aumentada pelos ganhos em termos de rendimento cul tural, que obriga a utilização de maior número de cortadores. Como se verá a seguir, esta idéia não é correta, tendo havido

* Na realidade a operação do plantio ainda é realizada com em prego de grande numero de trabalhadores. 
grande aumento de eficiência do trabalhador no processo de co Iheita da cana, tanto no corte propriamente dito, como no car regamento do produto para ser transportado para as usinas.

No início da década de 50 a quase totalidade das operações da caña era realizada manualmente ou com auxílio de tração animal. A cana era colhida crua (sem queimar) numa operação conjunta de cortadores e carregadores. O cortador "levara" 3 a 4 ruas da cultura por eito de serviço, cortando a cana, limpando-a das palhas e a depositando no chão em forma de pequenos feixes amarrados. Os carregadores (4 em cada cami nhão ou carreta) pegavam os feixes, punham-nos às costas, su biam uma escada e depositavam o produto colhido no caminhão ou carreta receptadora.

Já neste período (início de 50) a sazonalidade de mão-de-obra se mostrava presente na cultura da cana-de-açú car. Conta um ex-carregador entrevistado (hoje ele se encon tra inválido) que após a colheita, a necessidade de mão-deobra diminuia acentuadamente na lavoura de cana. Era comum os cortadores e carregadores de cana - que na quase totalidade mo ravam nas fazendas - se dedicarem, na fase da entressafra, ao cultivo de culturas de subsistência em áreas cedidas em parce ria pelos fazendeiros, ao mesmo tempo que ficavam disponíveis para trabalharem em troca de diária nas culturas principais (cana e café, principalmente), quando isto se mostrava necessá rio.

兰 O carregamento da cana era tido como um dos serviços mais duros na lavoura. Os trabalhadores costumam relatar casos de pessoas que se tornaram inválidas realizando esta opera çao = 
O crescimento do setor canavieiro no Estado de São Paulo, com a ampliação da capacidade das agroindústrias, estimulou o aumento da eficiência na operação de colheita do produto. Era necessário que, chegasse às móendas das usinas maior volume de cana cortada. No início da década de 60 os canaviais começaram a ser queimados, fazendo com que o corta dor não mais precisasse limpar as palhas da cana cortada e fa cillitando o deslocamento no interior da cultura. Dessa forma, aumentou-se o rendimento diário do trabalhador cortador, sen do que numerosos relatos dão conta que o rendimento foi dobra do.

"A gente cortava 2,5 toneladas por dia. Com a cana queimada dava para cortar 5 a 6 toneladas/dia".

No início dos anos 70 outra inovação começou a ser verificada na colheita da cana, com a introdução da carre gadeira mecânica que, eliminando os carregadores braçais, au mentou ainda mais o reidimento do trabalho. Já então o corta dor não precisava deixar a cana cortada em feixes, mas a depo sitava no chão em leiras contínuas, pois a "boca" da carrega deira passou a fazer o serviço de amontoamento do produto co Ihido. Também a largura do eito do trabalhador havia passado de 3 para 5 ruas, facilitando o processo de cärregamento mecâa nico do produto.

O efeito destas várias inovações sobre a ef $\underline{i}$ ciência da colheita de cana é assim descrito por AZZI(1972:2): "no caso de emprego do sistema de carregamento manual de canas enfeixadas, o rendimento físico médio do trabalho de corte si tua-se em torno de 3 toneladas por homem-dia. Com o emprego das máquinas carregadeiras e consequente queima dos canaviais, 
a operação de corte se reduz a um golpe de facão na base do colmo para separá-lo do solo, e outro na ponta, para separálo da folhagem. Nessas condições, o rendimento físico do tra balho de corte aumenta para $7 \mathrm{t} / H D$, em média. Considerando-se a operação conjunta de corte e carregamento, a introdução da carregadeira mecânica veio proporcionar uma eficiência física do trabalho que supera, no cômputo geral, a 10 vezes o proces so manual".

A carregadeira aumenta a produtividade do trabá Iho na colheita, mas apresenta o problema de prejudicar a qua lidade do produto colhido. No carregamento manual, não ocorre revolvimento do solo e as canas vão bastante limpas para as usinas. Já a máquina, ao juntar a cana cortada através de ras telamento mecânico, revolve a terra que adere ao produto co Ihido. Isto traz problemas ao setor industrial, pois implica em aumento nos custos pelá instalação de sistemas de lavagem da cana, além do que a presença de terra desgasta peças das usinas, especialmente as moendas, e prejudica o rendimento in dustrial do açúcar e álcool (MONTElRo et alii, 1983).

As alterações técnicas na colheita da cana-deaçúcar culminaram com a introdução do sistema de corte de 7 ruas na safra de 1983. Com essa mudança, além de aumentar a largura do eito do cortador em 2 ruas, as usinas que a insti tuíram exigiam que a cana cortada fosse depositada no chão em forma de montes ou "bandeiras" e não mais em leira contínua." Com isto o serviço de rastelamento mecânico feito pela carrega deira de cana é facilitado, reduzindo-se a quantidade de terra aderida ao produto colhido, o que por sua vez diminui os cus tos industriais, especialmente os de lavagem do produto, e au menta o rendimento industrial no processamento do açúcar e ál 
cool. Na parte agrícola o novo sistema também traz vantagens, pois a carregadeira e o caminhão receptador do produto colhido têm que passar menos vezes nos talhões, economizando combustí vel e diminuindo as injúrias às soqueiras, com isso propician do aumento no rendimento cultural da cana. Os ganhos gerais em termos de rendimento industrial e agrícola compensam uma eventual queda localizada no rendimento do trabalho na opera ção de corte em 7 ruas, estimado em torno de 20\% (GEBARA \& BAC. CARIN, 1983). Os efeitos da instituição das 7 ruas sobre os trabalhadores são discutidos no ítem 4.2. do próximo capítulo e as reações dos trabalhadores a este sistema no ítem 5.2.1.

Portanto, a colheita da cana passou por uma sé rie de mudanças técnicas que tenderam a aumentar a produtivida de do trabalho, seja na operação do corte de cana em si, seja no setor produtor de açúcar e álcool como um todo. A moderni zação da cultura não foi parcial ao longo do seu ciclo, pois assim como diminuiram as necessidades de mão-de-obra na fase de entressafra com a intrơução de tratores, as alterações na colheita, especialmente pela utilização da carregadeira mecâni ca e da queimada, também tiveram efeito no mesmo sentido, embo ra a intensidade possa ter sido diferente.

3.4. População e Relações de Trabalho na Agricultura de Ja boticabal

A série de transformações pelas quais passou a agricultura do município de Jaboticabal teve implicações dire tas sobre a distribuição da população local. Como pode ser 
visto no Quadro 9, entre 1940 e 80 , enquanto a população urba na aumentava em valor absoluto e em termos relativos, a popula ção rural apresentava tendência contrária. Em 1940, 59,4\% da população do município morava no setor rural e $40,6 \%$ no setor urbano; em 1980, oprimeiro valor havia se reduzido para $12,7 \%$ e o segundo aumentado para $87,3 \%$.

De 1940 a 1950, a população rural do município diminuiu em mais de 4.000 pessoas, bem mais do que a diminui ção verificada na década seguinte. Provavelmente esta queda se relaciona à já referida substituição da cultura cafeeira por pastagens, o que reduziu a necessidade de mão-de-obra na aģricultura local. Nesta década, inclusive, a população como um todo do município diminuiu, indicando a ocorrência de migra ção para outras regiões. O município ainda sentia os efeitos da crise da cultura cafeeira.

Quadro 9 - População rural urbana e total no município de Jabo ticabal, período 1940-80*

\begin{tabular}{ccccccc}
\hline \multirow{2}{*}{ Anos } & \multicolumn{2}{c}{ Popul. Rural } & \multicolumn{2}{c}{ Popul. Urbana } & \multicolumn{2}{c}{ Popul. Total } \\
\cline { 2 - 7 } & número & $\%$ & número & $\%$ & número & $\%$ \\
\hline 1940 & 17.664 & 59,4 & 12.079 & 40,6 & 29.743 & 100 \\
1950 & 13.313 & 48,3 & 14.252 & 51,7 & 27.565 & 100 \\
1960 & 13.162 & 39,0 & 20.610 & 61,0 & 33.772 & 100 \\
1970 & 9.187 & 23,7 & 29.592 & 76,3 & 38.779 & 100 \\
1980 & 5.958 & 12,7 & 41.044 & 87,3 & 47.002 & 100 \\
\hline
\end{tabular}

Fonte: FIBGE. Censos Demográficos, diversos números

* Os dados do Censo permitiram separar desde 1940 a população da área ocupada atualmente pelo município de Jaboticabal. 
De 1950 a 1960 a população rural pouco diminui em temos absolutos, ( 151 pessoas) embora a diminuição relati va tenha sido considerável $(9,3 \%)$. Nesta década a atividade pecuária perde importância em favor das atividades agrícolas, - que contribui para retenção da população no meio rural. A partir de 1960 a queda da população rural, tanto em termos ab solutos quanto relativos, se acentua e este fato provavelmente se relacione com as alterações verificadas na base técnica da agricultura local, tendo ocorpido aumento do capital constante e diminuição da necessidade da mão-de-obra por hectare cultiva do.

Acompanhando a diminuição da população rural, as relações de trabalho encontradas na agricultura do município vão se alterando. O colonato, ao longo do tempo, sofre uma sé rie de transformações, a parceria em determinada fase ganha im portância e, finalmente, o assalariamento monetário passa a predominar na agricultura de Jaboticabal. Os relatos dos tra balhadores e proprietários rurais entrevistados costumam consi derar o final da década de 1950 e início de 1960 como marco nas alterações das relaçóes de trabalho locais, quando o colo nato e a parceria são suplantados pelo assalariamento monetá rio exclusivo.

As alterações nas relações de trabalho no muni cípio ficam bem detalhadas no relato de um trabalhador de 63 anos, dos quais mais de 50 passados na região.

Sua família veio para a região trabalhar como colonos em uma fazenda de café. No contrato com o proprietá rio ficava estipulado que a família cuidaria de determinado nú mero de pés de café, realizando os tratos culturais e a colhei ta, recebendo em troca um salário monetário. Também podia-se 
utilizar as entrelinhas do café e uma área anexa à cultura principal onde eram cultivados arroz, feijão e mitho destina dos à subsistêricia da família e ao trato de alguns animais.

Praticamente toda a família participava dos ser viços agrícolas, especialmente na colheita do café, quando a necessidade de braços aumentava. Os serviços eram realizados quase todos "na base da enxada", normalmente, ou com auxílio de tração animal.

Embora os colonos não passassem necessidades em termos de alimentação, quase não thes sobrava dinheiro para ad quirir bens de consumo: "A gente era pobre, mas vivia com far tura" *

Com a perda de importância do café, este traba Ihador passou a trabalhar em diferentes culturas, especialmen te no algodão. Nesta cultura predominavam os contratos de par ceria, com o parceiro recebendo a meia ou a terça parte da pro dução.

De maneira geral o que parece ter acontecido, após a crise do café, é que uma parcela de colonos se transfor mou em parceirose outra parcela (certamente em menor número) conseguiu tornar-se proprietária rural pela compra de lotes de antigas fazendas de café. Não que o colonato de imediato te nha desaparecido da agricultura do município; ele é ainda en contrado na década de 50 em fazendas remanescentes de café e támbém em fazendas de cana, embora já bastante transformado e tendendo a se tornar uma relação de assalariamento monetário exclusivo.

Voltando ao relato do trabalhador entrevistado: em 1960 sua família veio para a cidade de Jaboticabal, Já en 
tão o trator era usado com maior intensidade nas operações agrícolas e os proprietários passaram a dificultar o acesso à terra para as culturas de subsistência. As relaçoes puramente monetárias entre proprietários rurais e trabalhädores tenderam a pievalecer, evidenciando que se tornava mais econômico o pa gamento de salário monetário do que a cessão de terra para o trabalhador garantir parte de sua subsistência.

Este trabalhador, após ter vindo para a cidade, trabalhou em empregos no setor urbano e também como bóia-fria pegando caminhão de turma. Nos dias de hoje, embora morando no meio urbano, ele continua a trabalhar no meio rural, não mais como volante, mas sim como trabalhador permanente.

Já outros ex-colonos e ex-parceiros deslocados do meio rural para a cidade continuam a trabalhar como volan tes, constituindo a maior parte do contingente de bóias-frias do município.

Com o acirramento da expansão da cultura da ca na-de-açúcar observado na década de 70, a importância do assa lariamento monetário aumenta ainda mais na agricultura do muni cípio. O crescimento da área plantada com cana foi acompanhą do de um processo de concentração da posse e da propriedade da terra, com os pequenos proprietários sendo pressionados a venderem ou cederem suas terras em arrendamento ou parceria pa ra os grandes fornecedores ou para as usinas. É na década de 70 que, como já discutido, a área média dos estabelecimentos aumenta de 87,2 ha para 141,3 ha, resultado da diminuição de seu número de 748 para 485. (a nota do rodapé da pg. 53 é váli da a ui).

Os proprietários rurais que perdem suas terras para os empresários da cana-de-açúcar dificilmente se proleta 
rizam. Com o dinheiro adquirido da venda de suas terras, a 1 guns compram propriedades agrícolas em regiões de fronteira, onde o preço da terra é mais barato e outros passam a viver de rendas ou pequenos estabelecimentos comerciais instalados no meio urbano. Entretanto, a expansão da cultura da cana-de-açú car. do,omiondp a "classe média" rural representada por peque nos produtores de alimentos e parceiros, evidencia no campo a dicotomia de duas classes sociais: a dos grandes proprietários, de um lado e a do proletariado, de outro. Nesta última a mar parte se constitui de bóias-frias.

Os dados dos Censos Agropecuários servem para confirmar as alterações ocorridas nas relações de trabalho na agrícultura do município.

Nos Quadros 10 e 11 são apresentadas respectiva mente a evolução da distríbuição do número e dárea dos esta belecimentos de acordo com a qualidade do responsável pela ex ploração. Observa-se que, em 1940, a importância dos parcei ros e arrendatários era considerável, sendo que ocupavam $28,2 \%$ do número de estabelecimentos e 10,1\% da área total.

De 1940 em diante a participação dos parceiros e arrendatários na administração dos imóveis diminui em rela ção à dos proprietários rurais até 1960, no que refere à por centagem de área ocupada e até 1970, no que refere à porcenta gem do número de estabelecimentos. Na dédaca de 70 , a partici pação relativa dos parceiros e arrendatários cresce acentuada mente, tanto no número de estabelecimentos quanto na área, es pecialmente nesta última.

Os dados censitários sugerem a ocorrência de 
Quadro 10 - Distribuição dos estabelecimentos agropecuários pe la qualidade do responsável pela exploração 194080

\begin{tabular}{ccccccc}
\hline & \multicolumn{3}{c}{ Qualidade do Responsável pelo Estabelecimento } \\
\cline { 2 - 7 } Anos & Proprietário & Arrend. eparceiros & \multicolumn{2}{c}{ Outros } \\
\cline { 2 - 7 } & número & $\%$ & número & $\%$ & número & $\%$ \\
\hline 1940 & 1.011 & 71,7 & 398 & 28,2 & 1 & 0,1 \\
1950 & 826 & 71,2 & 274 & 23,6 & 60 & 5,2 \\
1960 & 592 & 85,4 & 93 & 13,4 & 8 & 1,2 \\
1970 & 659 & 88,1 & 88 & 11,8 & 1 & 0,1 \\
1975 & 472 & 85,0 & 80 & 14,4 & 3 & 0,5 \\
1980 & 368 & 75,9 & 116 & 23,9 & 1 & 0,2 \\
\hline
\end{tabular}

Fonte: FIBGE. Censos Agropecuários, diversos números

Quadro 11 - Distribuição da área dos estabelecimentos pela qua lidade do responsável pela exploração 1940-80

\begin{tabular}{lcccccc}
\hline & \multicolumn{3}{c}{ Qualidade do responsável pelos estabelecimentos } \\
\cline { 2 - 7 } Anos & \begin{tabular}{c} 
Proprietário \\
\cline { 2 - 7 }
\end{tabular} & \multicolumn{1}{c}{ Arrend. eparceiros } & \multicolumn{2}{c}{ Outros } \\
\hline 1940 & 83.289 & 89,9 & 9.349 & 10,1 & 30 & 0,0 \\
1950 & 70.459 & 89,9 & 7.001 & 8,9 & 906 & 1,2 \\
1960 & 61.215 & 94,0 & 3.571 & 5,5 & 342 & 0,5 \\
1970 & 61.193 & 93,8 & 3.996 & 6,1 & 29 & 0,0 \\
1975 & 57.535 & 86,8 & 8.991 & 13,5 & 114 & 0,2 \\
1980 & 52.951 & 68,3 & 24.538 & 31,7 & 33 & 0,0 \\
\hline
\end{tabular}

Fonte: FIBGE. Censos Agropecuários, diversos números 
uma reversão na tendência de evolução da administração dos es tabelecimentos rurais em Jaboticabal, com a parceria voltando a ter papel importante na sua agricultura. Entretanto, estes dados devem ser melhor qualificados, sendo que os atuais par ceiros da agricultura de Jaboticabal em nada se assemelham aos antigos parceiros do algodão ou pequenos produtores de alimen tos. Os atuais arrendatários ou parceiros são, em sua maior parte, as usinas de açúcar éálcool, que alugam as terras dos pequenos proprietários e têm total controle sobre a administra ção da área. * 0 passo seguinte desta relação de "parceria" en tre usina e pequeno proprietário, muitas vezes, é a compra das terras deste por aquela.

Uma evidência de que os atuais parceiros e ar rendatários não se assemelham aos parceiros de 1940 pode ser conseguida pela análise de sua participaçãona área e no núme ro de estabelecimentos. Em 1940, a participação relativa dos parceiros e arrendatários na área era de $10,1 \%$, bem menor do que a participação no número de estabelecimentos, de $28,2 \%$. Já em 1980 os parceiros e arrendatários exploravam $31,7 \%$ da área dos estabelecimentos, embora detivessem o controle de so mente 23,9\% de seu número. Neste mesmo ano a área média dos estabelecimentos sob arrendamento ou parceria era de 211,5 ha, acima da área média dos estabelecimentos dos proprietários que era de 143,9 ha. Isto sugere que grande parte dos atuais par ceiros são as usinas de açúcar e álcool,plantadoras de gran

* Embora de fato a relação entre usinas e pequenos proprietá rios seja de arrendamento, na aparência legal ela surge mu $\bar{i}$ tas vezes como contrato de parceria, de forma que os descon tos do Imposto de Renda sejam menores para os proprietários da terra. 
des laveuras de cana-de-açúcar.

Por fim pode-se analisar, através do Quadro 12, a evolução do pessoal ocupado nos estabelecimentos agropecuá rios do município, no período 1940-80. De 1940 a 1950 o pes soal ocupado na agricultura diminui em mais de 4.000 pessoas, tendo decrescido principalmente o número de empregados perma nentes. Em parte este decréscimo se deve à mudança de crité rio entre os 2 Censos, pois em 1940 a determinação dos perma nentes era feita de maneira diferente e provavelmente engloba va os parceiros. Observe-se que, enquanto em 1940 nenhum par ceiro foi levantado nos estabelecimentos de Jaboticabal, em 1950 já foram constatados 1.352 parceiros. Entretanto, a ex plicação mais plausível é de maior importância para esta queda é a substituição do café pela pecuária observada na década e que teve um efeito maior sobre o pessoal assalariado (colonos) do que sobre a categoria responsável e membros não remunerados da família, cujo número também caiu, mas com menor intensida de.

A partir de 1950 duas tendências se tornaram ní tidas na agricultura de Jaboticabal. A primeira é a perda de importância dos responsáveis e membros não remunerados, que passaram de 42,1\% em 1950 para 15,8\% do pessoal ocupado em 1980. Já os assalariados (permanentes + temporários) aumenta ram sua participação no pessoal ocupado, passando de $46,2 \%$ em 1950 para 83,4\% em 1980*

Entre os assalariados, o temporário vem ganhan do importância ao Iongo dos anos, passando de 7,9\% do pessoa I ocupado em 1950 para 54,5\% em 1980, representando na atualida de mais da metade da força de trabal ho empregada na agricultu 


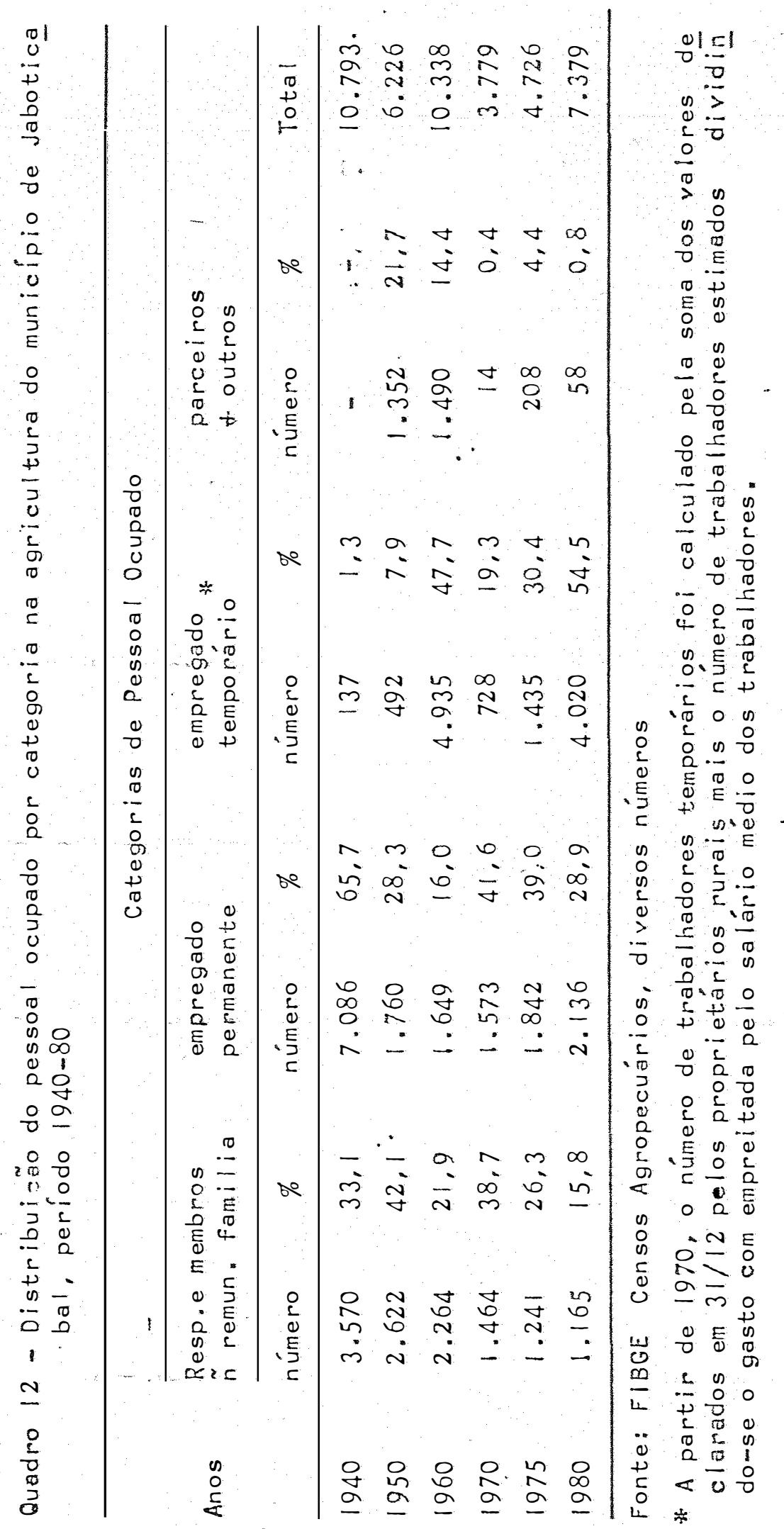


ra do município. Assim, fica evidenciado que na "fase cana vieira", a agricultura do município de Jaboticabal teve aumen tado grandemente o número de bóias-frias.

Os parceiros e outros tiveram sua participação relativa diminuída - até 1970 e depois apresentaram pequena re cuperação, sem atingir, entretanto, os níveis anteriormente ob servados em 1950 e 60 .

Um comentário merece ser feito sobre os dados de 1960, que fogem das tendências da evolução das categorias do pessoal ocupado, observadas de 1950-80. 0 que distoa neste ano é o grande número de trabalhadores temporários recenseados, 4.935 pessoas ou $47,7 \%$ do pessoal ocupado. Umá provável expli cação para isto pode ser encontrada na data de referência para a coleta de informações sobre o número de temporários: enquan to em 1960, esta data era primeiro de setembro (período coin cidente com a safra de cana) a partir"de 1970 esta data passou a ser 31 de dezembro, período de entressafra, quando a utiliza ção de temporários é consideravelmente reduzida. Daí a queda do número de temporários de 1960 para 1970. De qualquer forma, o grande número de trabalhadores temporários observados em 1960 serve como evidência de que o Estatuto do Trabalhador Ru ral (ETR) teve pequeno efeito na geração do bóia-fria, posto que sua implantação só ocorre posteriormente, no ano de 1963.

- Quadro 12 revela também que durante a década de 1970 ocorreu aumento de emprego no meio rural de Jabotica bal, tendo o pessoal ocupado passado de 3.779 para 7.379 pes soas: Entre 1970-75 o emprego cresceu à taxa de 5\% ao ano e 
entre 75-80 a $11 \%$ ao ano. Este fato está associado à expan são da cultura canavieira que, da mesma forma que o crescimen to do número de empregos, foi maior no segundo quinqüênio da dé cada.

$$
\text { interessante é que, enquanto o emprego rural }
$$

crescia na década de 70, a população rural decrescia (vide Qua dro 9), fazendo com que no ano de 1980 o pessoal ocupado na agricultura superasse a população do setor. Isto mostra que grande parte dos trabalhadores rurais do município (os bóiasfrias e mesmo trabalhadores permanentes) moravam no setor urba no.

* O crescimento entre 70 e 75 deve ser visto com muito cuida do, pois em 70 os dados do Censo não permitiram.calcular o número de trabalhadores temporários através do gasto com em reitada (vide observação do Quadro 12). Este aumento no eprego de 70 a 75, portanto, está muito influenciado por es ta mudança de critério. 


\section{4 - O MERCADO dE TRABALHO VOLANTE A AS CARACTERÍSTICAS ATUAIS DOS BÓ IAS-FRIAS}

Nesta parte as principais informações foram ob tidas de dados primários relativos a 50 questionários levanta dos junto a bóias-frias em agosto de 1983. Os objetivos des tes questionários eram caracterizar as condições de vida e de trabalho dos volantes, além de se tentar captar informações so bre a percepção dos trabalhadores sobre sua realidade e dos ní veis de organização desta categoria social.

Procurou-se selecionar trabalhadores de diferen tes bairros da cidade, de diferentes locais de trabalho e de diferentes culturas. No final do levantamento, observou-se que a maior parte dos volantes (42) trabalhava na cultura da cana e uma parte menor (8) na cultura da laranja, porque o 
período em que foi feito o levantamento coincidiu com a safra dessas duas culturas.

Dos 42 bóias-frias que trabalhavam na cana, $\quad 2$ se dedicavam à catação das sobras após a colheita, 2 ao arran quio de colonião das entrelinhas da cultura e 38 ao serviço de corte. Destes, 7 trabalhavam em engenhos, 16 em usinas de açú car éalcool e 15 em fornecedores.

Feita a classificação dos 50 questionários in i ciais, alguns trabalhadores foram selecionados para serem acom panhados pelo período de um ano (até agosto de 1984) com entre vistas periódicas, procurando-se aprofundar algumas informa ções obtidas inicialmente e também ter noção mais efetiva das variações das condições de trabalho e de vida do bóia-fria ao longo do ano. Tentou-se acompanhar mais de perto a instabili dade de trabalho do bóia-fria, especialmente entre o período de safra e entressafra.

Dos trabalhadores selecionados para o acompanha mento, um inicialmente se dedicava ao arranquio de colonião, 8 se dedicavam ao corte de cana, sendo um em engenho, 3 em us nas e 4 em fornecedores e 2 se dedicavam à colheita de laranjax Ao todo foram 11 trabalhadores acompanhados com 6 entrevistas bimensais.

Das seções que se seguem, a 4.1. descreve o mer cado de trabalho volante e os tipos de contrataçũo dos bóiasfrias, a 4.2. refere-se às condições de trabalho e a 4.3. tra ta da procedencia, da família e das condições de vida. 
4.1. O Mercado de Trabalho Volante e as Formas de Contrata ção dos Bóias-Frias

Como já descrito anteriormenterna DIRA de Ribei rão Preto ocorre uma tendência das sub-regiões se especializa rem em determinados produtos. Assim, por exemplo, próximo à cidade de Bebedouro localizam-se as firmas produtoras de suco de laranja e a área agrícola tendeu a se especializar na produ ção citrícola. Já o município de Jaboticabal, que conta atual mente com 2 usinas de açúcar e álcool, uma destilaria de álcool e 2 aguardenteiras, situa-se na área que se especializou na cultura da cana.

Tanto a colheita da cana-de-açúcar quanto a da Iaranja, que se estendem basicamente de maio a outubro, são realizadas, quase que totalmente, de forma manual. Por isso, a necessidade de mão-de-obra é muito grande nesta fase, sendo utilizado grande contingente de trabalhadores volantes.

Já nas operações de preparo do solo, plantio e tratos culturais, realizades na entressafra, a necessidade de mão-de-obra é bem menor em relação à safra, pelo fato destas operações apresentarem, de maneira geral, maiores índices de mecanização. A entressafra engloba, aproximadamente, os meses de novembro a abril.

Em decorrência, enquanto na entressafra se acen tua o excedente de mão-de-obra, na safra o aumento da demanda por força de trabalho, acirrado pela coincidência das colhei tas da cana e da laranja, provoca inclusive certa tendência de escassez de mão-de-obra na região. Na prática esta escassez não chega a se confirmar posto que, especialmente para "faze 
rem a safra" de cana, vêm para a região migrantes sazonais, pro venientes em grande parte do norte de Minas Gerais, mas também do sul da Bahia e, mais recentemente, do norte de Goiás. Esses migrantes são genericamente chamados de "mineiros" .

A variação durante o ano na demanda por mão-deobra nas regiões da laranja e da cana tende a se acentuar à medida que estas culturas expandem suas áreas, substituindo culturas anuais como milho, amendoim e algodão. Estas têm os seus ciclos produtivos coincidentes com a entressafra da cana e da laranja e, desta forma, serviriam como fonte de emprego para os volantes dispensados a final da safra da cana e da la ranja. Entretanto, como suas áreas tendem a diminuir, também diminui esta possibilidade de emprego.

Na literatura o mercado "típico", por assim di zer, de trabalhadores volantes tem sido apresentado como se caracterizando pela instabilidade e informalidade de vínculos de emprego, com o empreiteiro individual ocupando papel fundamental na-organização deste mercado. Como se discutiráa se guir, na regíão de estudo, estas características são encontra das predominantemente no período de entressafra. Já no perío do da safra de cana e Iaranja, o mercado de trabalho volante se apresenta mais estável e formal, com o empreiteiro indivi dual sendo substituído, na maior parte das vezes, pela contra tação direta ou pela contratação via firmas de empreita de mão-de-obra.

Na colheita da cana-de-açúcar, pode-se observar, na região de Jaboticabal, quatro formas de contratação de mãode-obra.

Ainda persiste, com importância reduzida, o em 
preiteiro individual "típico" que agencia os serviços de sua turma junto a pequenos fornecedores, detentores de pequenas áreas de cana, colhidas em um curto período de tempo. As tur mas desses empreiteiros "típicos", durante a safra, realizam também atividades auxiliares à colheita, como a "catação" da cana (operação referente ao recolhimento de restos de cana cor tada e não transportada) cujo pagamento é feito através de diária fixa. Desta forma, são usados nesta operação trabalha dores menos produtivos - como alcóolatras, velhos e menores - que não conseguem átingir a remuneração mínima no corte da cana, onde o pagamento é realizado por tarefa.

Outra forma de contratação é feita através de firmas de empreita de mão-de-obra, pessoa jurídica, com perso nalidade própria que contrata formalmente a mão-de-obra, assu mindo ela própria os encargos trabalhistas. Essas firmas de empreita resumem-se a meros escritórios, não tendo caminhões próprios para o transporte de turma* O que fazem é contratar trabalho com os produtores e repassar a empreiteiros indivi duais que arregimentam, fiscalizam e transportam a mão-deobra.

Muitas vezes a legalidade dos contratos destas firmas é apenas aparente. Têm surgido denúncias de que elas mantẽm somente pequena parcela de trabalhadores registrados e quando acontece algum problema com qualquer trabalhador, como um acidente de trabalho, tratam rapidamente de registrá-lo, mantendo a aparência legal.

*) Estes empreiteiros individuais, na entressafra, passam a trabalhar autonomamente, não mais vinculados às firmas de empreita. 
A contratação de firmas de empreita não diminui o custo social da mão-de-obra ou de direitos trabalhistas para - proprietário, já que eles são repassados aos preços oobrados pela firma. A vanțagem da uțilização da firma de empreita é que o proprietário se vê livre do gerenciamento da turma o que, por outro lado, torna menor seu controle sobre a mão-de-obra.

Uma terceira forma de contratação dos cortado res de cana é a que se estabelece entre proprietários rurais e os "mineiros". No início desta pesquisa sabia-se da utiliza ção dos "mineiros" apenas por uma usina da região, famosa pe los seus barracões de trabalhadores. Com o desenvolvimento do estudo, fói-se percebendo que a utilização dos "mineiros" era muito mais generalizada do que se pensava inicialmente, sendo que número considerável de fornecedores, inclusive peque nos, faz uso deste tipo de mão-de-obra.

Os "mineiros" são migrantes sazonais, que pro vêm especialmente da região seca do norte de Minas Gerais, on de são pequenos produtores, na sua maior parte. Premidos pe los baixos rendimentos auferidos na regi ão de origem, associa dos aos problemas da seca, eles vêm "fazer a safra" na região de Ribeirão Preto. Uma parcela desta mão-de-obra aloja-se nas cidades da região - Barrinha e Guariba, especialmente - e suas relações com os empreiteiros e proprietários rurais se assemelham às dos outros volantes da cidade.

Outra parcela, que se quer aqui destacar, alo ja-se interior das unidades produtivas, em barracões impro visados com grande número de moradores, apresentando precarís simas ćondições de higiene e conforto. Residentes nas proprie dades e com poucos contatos com o meio urbano e com outros tra 
balhadores, - estes migrantes ficam sob forte controle dos pro prietários, os quais descumprem grande parte das promessas fei tas ao arregimentar esse pessoal, além de exercerem fiscaliza ção severa sobre os seus serviços.

Pelö fato de os "mineiros" residirem nos imó veis rurais, os proprietários contam com maior flexibilidade na utilização da mão-de-obra, seja no ajustamento da jornada de trabalho, seja nos dias trabalhados na semana. Os "minei ros", não tendo que ser transportados, podem mais facilmente começar a trabalhar mais cedo e terminar mais tarde; do mesmo modo que são mais facilmente "estimulados" a trabalharem aos domingos, dependendo das necessidades de cana cortada dos pro prietários rurais.

É normal os "mineiros" trabalharem com carteira assinada. Entretanto, costumam apresentar constantes reclama ções que ao final da safra são lesados nos acertos com os pa trões. Isto porque a pressa de voltar as suas regiões de ori gem, para o plantio da agricultura de subsistência, deixa pou co tempo para que lutem pelos seus direitos trabalhistas. Tam bém, os poucos contatos no meio urbano dificultam aos "minei ros" terem acesso ao Sindicato de Trabalhadores e à Justiça do Trabalho *

Finalmente, na colheita da cana pode-se consta tar o caso em que a contratação dos volantes é feita diretamen

* Os proprietários costumam manter em suas propriedades um es toque de bens como cigarros e outros artigos, além de reali zarem o pagamento só no final do mês, procurando evitar qué os trabalhadores se desloquem toda a semana para a cidade. 
te pelo produtor, sendo o empreiteiro "absorvido" pelo proprie tári 0 empreiteiro, que algumas vezes é transformado em em pregado do proprietário, continua responsável pela arregimenta ção, fiscalização e transporte de mão-de-obra volante. Entre tanto, não mais exerce controle direto sobre a remuneração do volante, que passa a ser realizada diretamente pelo proprietá rio rural.

O contrato de trabalho direto entre volante e proprietário, na maier parte das vezes, é temporário, abrangen do o período da safra, de aproximadamente 6 meses. Do preço pago ao volante por tonelada cortada, uma parcela é retida pa ra ser paga ao final da safra, referente ao 130 salário, fé rias e indenização. Havendo rompimento do contrato de traba Iho antes do término da safra, por parte do trabalhador, este perde o direito às férias e indenização. 0 contrato também es tipula o pagamento do descanso semanal remunerado para aquele trabalhador que estiver presente ao serviço toda a semana, de segunda a sábado. Portanto, o contrato de trabalho é uma for

* Apesar da inexistência do controle direto sobre a remunera ção dos volantes, tem-se constatado que indiretamente o empreiteiro pode se beneficiar do ganho dos trabalhadores. Uma forma é aquela em que os empreiteiros são proprietários ou fazem acordos com os donos de armazéns e bares, dos quais recebem comissões sobre os gastos efetuados pelos volantes. Outra forma torna-se possível pelo fato dos empreiteiros se rem responsáveis pela medição da quantidade de cana corta da; muitas vezes eles subestimam a produção de alguns trabā Ihadores, repassando a diferença para outros, amigos, aman tes ou parentes porventura existentes na turma. Além disso as relações pessoais entre os bóias-frias e empreiteiros costumam ser muito fortes e os primeiros, sempre premidos por necessidades financeiras, tomam dinheiro emprestado dos segundos, pagando elevadas taxas de juros. 
ma de "obrigar" os volantes a trabalharem todos os dias duran te a safra da cana, oferecendo garantia aos proprietários de fornecimento contínuo de mão-de-obra nesse período.

A necessidade de se garantir o fornecimento da mão-de-obra para a safra faz com que as usinas e mesino alguns fornecedores comecem a formar as turmas de cortadores cerca de 30 a 40 dias antes do início da colheita, mesmo que nesse in tervalo os trabalhadores se dediquem a serviços facilmente dis pensáveis. Nas palavras de um trabalhador entrevistado:

"A usina contrata a gente mais de um mês antes do início da safra e põe a gente para capinar amendoim (erva daninha) no meio da cana. Só faz isso para garantir o pessoal na safra".

Algumas usinas chegam mesmo a fazer novos con tratos de trabalho com volantes na entressafra, permanecendo os trabalhadores empregados nas propriedades o ano todo, o que significa para essas usinas garantia de fornecimento de mãode-obra na safra seguinte. 0 contrato continua sendo semes tral, sendo que entre os contratos de safra e entressafra, são dadas "férias" não remuneradas de 15 a 30 dias. aos trabalhado res. Os volantes não adquirem, desta forma, tampo de serviço em seus empregos e convivem com uma situação dúbia, pois, embo ra possam estar já há 3-4 anos no mesmo emprego, ainda são "temporários".

Na entressafra essas usinas mantêm os volantes ocupados em operações como o plantio de novas áreas de cana, operação que normalmente utiliza contingente razoável de mãode-obra. Também empregam os volantes na carpa, cuja necessida de de mão-de-obra é intencionalmente aumentada pela menor uti 
lização de herbicidas, em serviços gerais (limpeza de carreado res etc.) e no cultivo de culturas como o amendoim e a soja nas áreas de reforma da cana.

A manutenção das turmas fixas pelas usinas é possibilitada pela adequação de operações na entressafra (me nor utilização de herbicidas, por exemplo) e também pelo fato de que a expansão acelerada da área de cana chega a estender o período da colheita para 7 ou 8 meses. Desta forma, diminui a sazonalidade de necessidade de mão-de-obra torna-se viável a contratação das turmas fixas.

A manutenção das turmas fixas garante maior se gurança no fornecimento de mão-de-obra para a colheita, melhor qualificação do volante pela repetitividade das operações agrí colas, controle maior sobre os bóias-frias e maiores possibili dades de selecionar os trabalhadores mais produtivos e menos contestadores, além de melhorar as condições de reprodução da força de trabalho, implicando na elevação da produtividade da mão-de-obra.

As turmas fixas não são encontradas genericamen te em todas as usinas; pelo contrário, tendem a ser encontradas apenas nas agroindústrias mais eficientes e organizadas. turma fixa revelaria uma nova fase na administração da mão-deobra ou na exploração da força de trabalho pelas agroindús trias de açúcar e álcool, fase esta em que as empresas começam a pensar em medidas de promoção humana, como a distribuição da comida balanceada e quente e suplementação alimentar com leite de soja, por exemplo, com a finalidade de tornar o trabalhador mais produtivo e, em consequência, aumentar os lucros da empre sa. Frise-se que isto deve ser encarado muito mais como uma tendência incipiente, constatada em pequeno número de empre 
sas, do que como regra geral que atingisse a maior parte dos bóias-frias.

Na cultura da laranja, as turmas fixas não são constatadas. Isto porque são as indústrias de suco que admi nistram a colheita do produto, ao passo que os pomares não são normalmente de sua propriedade. Elas utilizam a mão-de-obra volante somente para a colheita da laranja.

No mercado de apanhadores de laranja o que pre domina é a contratação direta dos volantes ou através das fir mas de empreita, com os trabalhadores tendo as carteiras de trabalho assinadas pelo período da safra, que também se esten de por aproximadamente 6 meses.

No período de safra da cana e da laranja, quase todos os volantes do município são empregados nestas duas cul turas. Uma pequena parcela de trabalhadores, normalmente me nos produtivos, se dedica a serviços esporádicos e gerais como limpeza de brejos, arranquio de colonião, etc. Neste caso são agenciados por empreiteiros individuais, não têm a carteira de trabalho assinada e, consequentemente, não recebem os direitos trabalhistas.

De maneira geral, o que ocorre nas safras de ca na e laranja é a contratação mais formal e estável dos volan tes, inclusive com o empreiteiro individual perdendo importân cia em favor da contratação direta ou da contratação via fír mas empreiteiras de mão-de-obra, permitindo melhor controle e segurança de fornecimento da força de trabalho aos proprietá rios rurais e industriais. Esta segurança é importante, dado o aumento da demanda por mão-de-obra utilizada simultaneamente nas colheitas da laranja e da cana, o que acirra a disputa pe 
la força de trabalho.

Além disso, não se pode esquecer a vinculação da produção agrícola da cana e da laranja às agroindústrias de açúcar e álcool e de suco. Estas necessitam de um fornecimen to contínuo da matéria-prima - sob o risco das máquinas fica rem paradas -, de maneira que a melhor organização dos cortado res de cana e dos apanhadores de laranja torna-se indispensá vel ao bom andamento das indústrias.

"Importa assinalar, particularmente quando nos ocupamos em analisar o processo de trabalho, que na relação de mútua dependência entre estes dois setores (agrícola e indus trial) predomina a indústria. Não se trata de uma influência formal ou claramente explicitada, isto é, o modo de organiza ção do sistema industrial não determina como os trabalhadores devem ser agregados ou distribuídos nas operações agrícolas, mas o que a usina faz é determinar as condições, especifica ções e rítmos com que necessita receber a matéria-prima, condi cionando assim o planejamento que deve ser realizado obedecen do estes parâmetros" (FLEURY et alii, s.dx:10). "O que temos observado é que quanto às empresas agroindustriais oligopoliza das (agroindústrias canavieiras), o desenvolvimento que se pro cessa tem levado a que assumam mais diretamente o controle de todo o processo produtivo, com a mecanização e o gerenciamento da parte agrícola, instaurando o controle direto sobre o traba I ho" (BARBAN, $s, d,: 1$ ).

Ao final das safras de cana e de laranja ocorre mudança brusca no mercado de mão-de-obra volante. Como já di to anteriormente, algumas usinas tendem a mariter a maior parte dos seus cortadores empregados no período da entressafra, pạ 
gando diária menor do que a remuneração obtida durante o corte de cana. Entretanto, outras usinas e os fornecedores dispensam grande parcela da mão-de-obra empregada na colheita, de forma que somente pequena.porcentagem de vólantes consegue manter o emprego nas propriedades em que trabalham durante a safra.

Aos trabalhadores dispensados pelos produtores de cana juntam-se os trabalhadores dispensados da colheita da laranja, engrossando assim o excedente de mão-de-obra no merca do de trabalho volante.

Esse excedente de mão-de--obra, como já descrito anteriormente, é acentuado pelo fato de que a expansão das cul turas da cana e laranja diminui a área plantada com outras cul turas como algodão, milho e amendoim, que utilizam a mão-deobra volante no período que coincide com as entressafras da ca na e laranja.

As atividades que geram emprego na entressafra são as capinas de diversas culturas, serviços gerais (limpeza de brejo, arranquio de colonião), raleação do algodão, colhei tas de algodão e amendoim, "catação" do milho, etc., as quais normalmente são de curta duração e que não mobilizam o trabą Ihador volante por grande período de tempo na mesma proprieda de* As operações, nesta fase, são curtas e instáveis. Além disso é nesta fase que as chuvas são mais freqüentes implican do em perdas de dias de trabalho pelos volantes. O desemprego aumenta acentuadamente.

O proprietário rural tende a não mais controlar diretamente a mão-de-obra, voltando o empreiteiro "típico" ou individual a representar o papel primordial na arregimentação 
e organização do mercado de trabalho volante.

Nesta fase os bóias-frias trabalham de maneira geral, esporadicamente, em diversas propriedades, sob responsa bilidade direta do empreiteíro, sem carteira assinada, sem di reito às férias, a domingo remunerado, sem receber os direitos trabalhistas, só recebem pelos dias trabalhados, convivem com constantes períodos de desemprego e mudam constantemente de em preiteiros. O nível salarial e a renda familiar diminuem, mes mo porque membros das famílias (as mulheres, principalinente) que trabalhavam durante a safra têm dificuldades de arrumar em prego no meio rural na entressafra, sendo comum se transforma rem em empregadas domésticas no meio urbano. Os homens, algu mas vezes, trabalham na construção civil como serventes de pedreiro.

4.2. Condições de Trabalho

As condições gerais de trubalho no período das safras de cana e laranja dos 50 bóias-frias entrevistados em agosto de 1983 são apresentados no Quadro 13. Pela coluna do total observa-se que $38(76 \%)$ dos bóias-frias entrevistados. trabalhavam no corte da cana, sendo 7 (17\%) em engenhos de pin ga, $16(32 \%)$ em usinas e $15(30 \%)$ em fornecedores. Do restan te, $2(4 \%)$ trabalhavam na catação de cana, 2 no arranquio de colonião e $8(16 \%)$ na colheita de laranja.

Pela linha do total observa-se que, no que se refere ao período de emprego, predominavam na amostraosbóiasfrias com trabalhos temporários, ou seja, cuja duração do em prego na época da entrevista era de no máximo igual ao período 


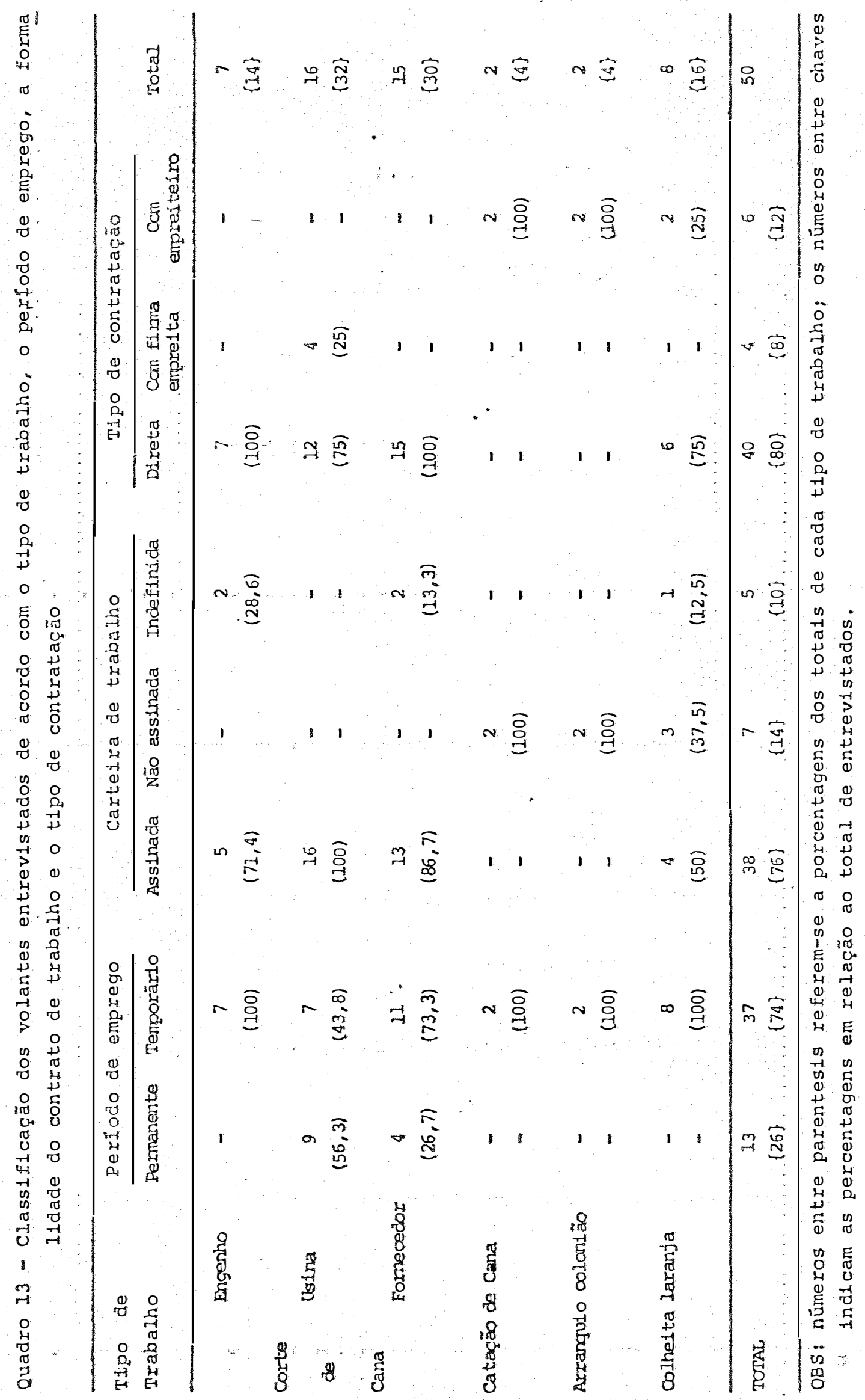


da safra de cana e de laranja, de aproximadamente 6 meses. Es tes eram em número de 37 ou $74 \%$ da amostra, en quanto que os bóias-frias com trabalho permanente, ou seja, que faziam tam bém contrato de entressafra no mesmo local de trabalho eram 13 $(26 \%)$

Quanto à formalidade dos vínculos empregatícios, observa-se que $38(76 \%)$ dos entrevistados trabalhavam com car teira assinada, $7(14 \%)$ sem carteira assinada e para 5 (10\%) trabalhadores a situação era indefinida. Neste caso a cartei ra ainda estava retida pelo empregador ou o trabalhador prefe ria manter em sua carteira o registro anterior de emprego urba no, podendo, desta forma, utilizar os serviços de assistência médica do INPS ao invés do Funrural.

O tipo de contratação predominante entre os en trevistados era o diretamente realizado pelo proprietário ru ral, sendo que $40(80 \%)$ dos bóias-frias estavam nesta situação. Do restante, $6(12 \%)$ eram contratados via empreiteiro indivi dual e $4(8 \%)$ via firma de empreita. No caso da contratação direta o empreiteiro passa a não mais ter controle sobre o pa gamento do bóia-fria e, em alguns casos, chega a se transfor mar em empregado das empresas rurais.

Dos 7 trabalhadores que se dedicavam ao corte de cana nos engenhos, 5 moravam em uma mesma casa, sendo 4 com famílias formadas e um como pensionista. As 4 famílias haviam chegado recentemente do norte do Estado do Paraná à procura de melhores condições de trabalho na cultura da cana em São Pau Io.

Nos engenhos predominava a contratação direta dos volantes e a assinatura das carteiras de trabalho através 
de um contrato por tempo determinado i gual à duração da safra.

Foram entrevistados trabalhadores de 5 diferen tes usinas de açúcar e álcool, só duas localizadas no municí pio de Jaboticabal. É entre os bóias-frias das usinas que se observa a maior importância do período de emprego permanente. Nove ou 56,3\% dos volantes de usinas já há alguns anos vem fa zendo novos contratos de aproximadamente 6 meses para a entres safra. Todos os trabalhadores de usina tinham carteira assina da e suas contratações eram feitas diretamente (na maior parte das vezes) ou através de firmas empreiteiras de mão-de-obra.

Entre os cortadores de cana que trabalhavam pa ra fornecedores também se observou o período permanente de em prego, embora relativamente menos importante que no caso das usinas. Dos 15 cortadores de fornecedores, a maior parte era temporária (só contrato de safra) e apresentava carteira de trabalho assinada. A totalidade era contratada diretamente pelo produtor.

A situação mais precária de emprego apareceu en tre os trabalhadores que realizavam serviços de catação de ca na e apranquio de colonião, embora o pequeno número de observa ções neste caso prejudique a confiabilidade das informações. De qualquer forma, observou-se que a totalidade destes traba Thadores era contratada via empreiteiro individual, não tinha carteira de trabalho assinada e era empregado temporário. Além disto, ficava sujeitos a instabilidade de emprego maior do que a dos outros entrevistados, posto que nem mesmo o contrato de safrista possuia.

Os apanhadores de laranja entrevistados eram to dos temporários, com a metade tendo carteira de trabalho assi 
nada e, além da contratação direta, foi observado a contratạ ção através de empreiteiro individual. O pequeno número de apanhadores de laranja entrevistados e a inclusão na amostra de 2 trabalhadores que apanhavam laranja para comércio em po mar de um pequeno produtor, sendo agenciados via empreiteiro e sem carteira assinada, podem estar mascarando as reais caracte rísticas da contratação da mão-de-obra volante pelas indús trias de suco de laranja. Outras informações, que não as obti das diretamente dos questionários, permitem inferir que o re gistro em carteira de trabalho é maior do que os $50 \%$ apresenta dos e também que as firmas de empreita têm importante partici pação na organização do mercado de apanhadores de laranja.

De maneira geral se observa no período de sa fra a formalização do contrato de trabalho, assegurando ao vo lante maior garantia de emprego e acesso aos direitos previden ciários e trabalhistas. Pelo Quadro 14 pode-se observar a por centagem de trabalhadores que recebem os direitos trabalhistas.

Quadro 14 - Recebimento dos direitos trabalhistas pelos bóiasfrias entrevistados

Tipo de

Recebe Não Recebe Não Sabe

direito

№ \% total № \% total № \% total Total

Domingo

remunerado 3

130 salário 31

3162

$62 \quad 16$

32

3

6

50

Férias

30

62

13

26

6

12

50

Dias de

chuva

$5 \quad 10$

44

88

5

10

50 
Por volta de $60 \%$ dos entrevistados disseram re ceber o domingo remunerado, o 13 o salário e as férias. Os dias em que chovia e o volante não podia trabalhar, a maioria (88\%) disse nada receber. Provavelmente o recebimento do do mingo remunerado, férias e 13 o salário estão subestimados nás informaçoes dos trabalhadores, porque os pagamentos realiza dos, grande parte das vezes, não são acompanhados de comprovan tes. O trabalhador só recebe um cheque do total ganho na sema na ou na quinzena, sem que the seja especificada qual a parcela que trata do salário dos dias normais de trabalho, qual parce la que trata do domingo remunerado. Além disso, o volante tem pequeno controle sobre sua produção diária, no que se refere ao número de metros de cana-de-açúcar cortados ou ao número de caixas de laranja colhidas. No acerto de final de safra fica difícil determinar se o montante de dinheiro recebido corres ponde às reais porcentagens da produção do trabalhador que the deveriam ser pagas à título de férias ou 13o salário ou se ocorre subestimação destes valores.

A inexistência de comprovantes de pagamento e o pequeno controle dos volantes sobre sua produção diária, ao mesmo tempo que causam insegurança ao trabalhador, garantem ao empresário rural ou às firmas de empreita de mão-de-obra a pos sibilidade de que se cometam arbitrariedades no pagamento dos salários e dos direitos trabalhistas aos bóias-frias. 弚 Os

*- Da greve dos cortadores de cana de Guariba e dos apanhado res de Iaranja de Bebedouro, que serão discutidos posterior mente, um dos ítens dos acordos estabelecidos com os empré sários rurais estipulava que o trabalhador deveria receber comprovante diário de sua. produção e envelope de pagamento, onde fossem especificadas as diversas parcelas do salário recebido. Na prática, entretanto, estes ítens foram siste maticamente descumpridos no decorrer da safra de 1984. 
trabalhadores apresentam constantes reclamações de que no acer to de final de safra nunca recebem o que thes é devido e que sua produção diária, seja o número de caixas de laranja colhi das, seja o total de toneladas de cana cortadas, é subestima da.

O caso da cana é bem típico. Os trabalhadores têm noção da quantidade cortada em termos de metros ou distân cia* Só que o pagamento é realizado em termos de toneladas ou peso. A conversão dos metros cortados em toneladas é realiza da nas balanças das usinas, longe do controle dos trabalhado res, dando margem a que aconteçam roubos na produção diária do trabalhador:

Além destes problemas, a simples formalização dos contratos de trabalho nas safras de cana-de-açúcar e laran ja não define aos bóias-frias a renda a ser recebida mensalmen te, porque eles recebem de acordo com a produção realizada no mês, ou seja, de acordo com o número de toneladas de cana cor tadas ou de caixas de laranja colhidas. E esta, produção fica sujeita aos fatores climáticos; em meses muito chuvosos, como foram os de maio e setembro de 1983, os bóias-frias pouco trá balham, pouco produzem e, consequentemente, pouco recebem. Tam bém, quando ficam doentes, os bóias-frias nada recebem,pois os empregadores costumam pagar os dias parados somente em casos de acidentes no trabalho ou no transporte e não em caso de do en ça *

A existência de contratos formais de trabalho e a maior estabilidade de emprego faz com que a remuneração mé dia do volante tenda a aumentar no período da safra, embora continue extremamente baixa, como pode ser visto no Quadro 15 . 
Quadro 15 - Classificação dos bóias-frias de acordo com o ní vel salarial no período da safra, baseado no salá rio mínimo (SM)

\begin{tabular}{lccc}
\hline Níveis de salário & Número & $\%$ & $\%$ acumulada \\
\hline até I SM & 7 & 14,6 & 14,6 \\
de 1-2 SM & 26 & 54,2 & 68,8 \\
de $2-3$ SM & 12 & 25,0 & 93,8 \\
de $3-5$ SM & 2 & 4,2 & 98,0 \\
de $5-8$ SM & 1 & 2,1 & 100 \\
\hline Total & 48 & 100 & 100 \\
\hline
\end{tabular}

OBS 1: faltam duas informações por inconsistência nos dados. OBS 2: o salário mínimo considerado foi o que vigorou de maio a novembro de 1983, i gual a Cr\$34.776.

A maior parte dos trabalhadores, 26 ou $\quad 54,2 \%$ dos entrevistados, ganhava de l a 2 salários mínimos. A se guir, vinha a parcela de trabalhadores que ganhava de 2 a 3 sa lários mínimos, 25\% dos entrevistados, e a que ganhava menos que 1 salário mínimo, $14,6 \%$ dos entrevistados. A grande maio ria dos trabalhadores, próximo a 94\%, ganhava menos que 3 salá rios mínimos e só houve um trabalhador que declarou ganhar mais que 5 salários mínimos mensais.

Os baixos níveis salariais são conseguidos sob condições de trabalho bastante árduas, especialmente no corte de cana, com o trabalhador se sentindo estimulado a aumentar o seu rítmo de trabalho, já que é pago pela pródução realizada.

o bóia-fria percebe o corte de cana como um ser viço muito fácil de ser aprendido, mas muito duro de ser reali 
zado, desgastando a saúde e o corpo do trabalhador.

"Qualquer um, mesmo bobo, faz o serviço do cor te de cana, se o nego não souber cortar cana, não sabe fazer nada".

"É preciso ter opinião para cortar cana, não é um serviço mole".

"A gente está vendo o pessoal cada vez mais fra co e doente. Tem gente que não para nem para comer direito, beber água e café. Não se pode perder tempo".

"Eu trabalho até domingo para ganhar Cr\$2.800." E chego a noite eu não consigo dormir de dor no corpo".

O aumento do rítmo de trabalho na safra da cana provoca alterações, inclusive no horário de almoço dos traba Ihadores. Eles, após desembarcarem dos caminhões de turma e antes de iniciarem o corte, já se alimentam de parte de suas bóias-frias, guardando a sobra para ser ingerida rapidamente por volta das 10 horas. Comendo logo cedo, além de se substi tuir o café da manhã no fornecimento de energia para o traba Iho, o volante evita paradás mais demoradas durante o dia, pro curando com isto manter o rítmo de trabalho.

Alguns trabalhadores chegam a realizar disputas entre si para aumentar o rendimento diário no corte. Um dos trabalhadores entrevistados contou que no final da safra ele e mais três trabalhadores resolveram "tirar" todo um talhão de cana em um dia. Neste dia eles quase não pararam para comer e beber água e conseguiram cortar cada um 320 metros de cana - a média é 80-100 metros cortados/dia. Na volta para a c.idade, um dos trabalhadores sentiu-se mal no caminhão, tendo cãibras 
em todo corpo. Precisou de tratamento hóspitalar, ficando 2,5 dias internado.

Na safra de cana-de-açúcar de 1983 um fator adi cional contribuiu para aumento do rítmo de trabalho dos volan tes, que foi a instituição do corte de cana por 7 ruas. Dados obtidos junto às próprias usinas de açúcar e álcool permitiram estimar uma queda de $20 \%$ no rendimento do trabalhador pela pas sagem das 5 para 7 ruas (GEBARA \& BACCARIN, 1983). Entre os trabalhadores entrevistados a queda em seus rendimentos foi unanimimente declarada.

A passagem das 5 para as 7 ruas aumenta a largu ra do eito de trabalho, exigindo do bóia-fria mais deslocamen tos laterais e maior esforço para depositar a cana cortada na rua central do eito. A sequência de movimentos realizada nas 5 ruas: corte da cana e seu lançamento à rua central teve que ser substituída, nas duas ruas adicionadas, pela seguinte se quência: corte da cana, carregamento nos braços e dep•sição na rua central.

A maior complexidade de movimento nas 7 ruas exige do trabalhador volante um esforço físico maior, na tenta tiva de se manter a produção antes obtida nas 5 ruas. Esta ne cessidade de maior esforço físico encontra-se limitada pelo fato do bóia-fria já trabalhar próximo ao limite de sua força física, além de que normalmente apresenta estado nutricional deficiente. Juntamente com a implantação das 7 ruas, foi veri ficado entre os trabalhadores maior ocorrência de dores muscu lares, cãibras e desmaios. Isto atingiu, de modo geral, todos os bóias-frias, mas foi mais constatado entre os cortadores mais velhos e entre as mulheres. Nas palavras dos trabalhado res: 
"Não há braço que aguente as 7 ruas".

"O sistema de 7 ruas reduz a vida do homem, pe lo desgaste físico e fome. Os cortadores mais fracos estão perdendo dinheiro. Está havéndo desmaio pelo excesso de esfor ço físico para tentār manter a diária igual ao do sistema de 5 ruas".

"Dá dó ver as pessoas mais velhas cortar nas 7 ruas".

"Um homem cortando cana sem comer, comendo só abobrinha, não agüenta. E com as 7 ruas tá pior. A gente per de as forças mais rápido. Tem mulher e velho desmaiando na roça e não agüuenta o tranco de pegar o eito maior. A carne pa ra o homem é igual o milho para o burro".

O desgaste do volante pelo rítmo acentuado de trabalho é agravado pelas condições insalubres do corte da ca na e pela insolação a que fica exposto ${ }^{*} /$ Acontece de, ao fi nal da safra, alguns trabalhadores estarem fisicamente esgota dos e precisando de tratamento médico. Também acontece de to marem injeção de glicose, procurando uma fonte extra de ener gia para o trabalho.

A jornada de trabalho dos bóias-frias tende a ser alongada, ultrapassando o limite legal de 8 horas/dia. Dos entrevistados, somente $29 \%$ trabalhavam 8 horas ou menos/dia, a maioria (51\%) trabalhava de 8 a 9 horas e $20 \%$ mais de 9 horas diárias (Quadro 16).

* Existem trabalhadores que procuram morar nos locais de tra balho, normalmente em condições precárias, para que possam iniciar a jornada de trabalho mais cedo, parar durante o pe ríodo de maior insolação e reiniciar o trabalho no final dá tarde, até ficar totalmente escuro. 
Quadro 16 - Duração da jornada de trabalho dos bóias-frias entrevistados

\begin{tabular}{rrr}
\hline $\begin{array}{l}\text { Jornada de } \\
\text { trabalho (horas). }\end{array}$ & Número \\
\hline $\begin{array}{c}\text { menos } 8 \\
8\end{array}$ & 6 & 12,2 \\
$8-9$ & 8 & 16,3 \\
$9-10$ & 8 & 51,1 \\
+10 & 2 & 16,3 \\
\hline Total & 49 & 4,1 \\
\hline OBS: uma informação apresentou inconsistên \\
cia.
\end{tabular}

A Ionga jornada de trabalho acrésce-se o tempo gasto no transporte da cidade para o campo e vice-versa, fazen do com que todos os volantes entrevistados ficassem à disposi ção do empregador mais de 10 horas/dia, concentrando as infor mações entre 11 e 12 horas $(36,7 \%$ das respostas) e 12 a 13 ho $\mathrm{ras} / \mathrm{dia}(40,8 \%)$, conforme dados do Quadro 17 . Os trabalhado res da laranja são os que mais tempo ficam fora de casa, posto que os pomares tendem a ser mais distantes da cidade de Jaboti cabal do que as lavouras de cana. Os apanhadores de laranja, normalmente, saem às 5 horas de casa e só voltam às 19 horas, perfazendo um total de 14 horas diárias.

A Ionga jornada de trabalho deixa pouco tempo para o bóia-fria conviver com a família e com os companheiros 
Quadro 17 - Tempo do bóia-fria à disposição do empregador (jornada de traba Tho, tempo de transporte, almoço e descanso)

\begin{tabular}{|c|c|c|}
\hline $\begin{array}{l}\text { Tempo a disposição } \\
\text { do emprégador(horas) }\end{array}$ & Número & $\%$ \\
\hline $10-11$ & 6 & 12,3 \\
\hline $11-12$ & 18 & 36,7 \\
\hline $12-13$ & 20 & 40,8 \\
\hline+13 & 5 & 10,2 \\
\hline Total & $\Delta 9$ & 100,0 \\
\hline
\end{tabular}

de serviço.:- Também sobram-lhes poucas horas para o descanso, especialmente para as mulheres que acordam mais cedo para pre pararem a refeição do dia. E as perturbações no sono são cons tantes, com medo de não acordar na hora de pegar o caminhão e perder o dia de serviço.

"Eu acordo sempre umas 2 horas antes de pegar o caminhão e não durmo mais, senão perco o dia. Acontece de uns 2 dias/semana eu não conseguir dormir".

É idéia comum entre os bóias-friss de que ape nas um dia de descanso semanal não basta para recuperaro corpo

*) Durante as entrevistas observou-se que, fora do trabalho,os bóias-frias não estabelecem maiores contátos com os compa nheiros de turma, embora muitos morem próximos uns dos o $\underline{\underline{u}}$ tros. 
dos esforços feitos durante a semana. Algumas vezes acontece de o bóia-fria faltar um dia normal de serviço, o que lhe sai extremamente caro, pois além de perder a remuneração deste dia, perde também o descanso semanal remunerado.

0 regime extenuante de trabalho traz implica ções no que se refere aos acidentes de trabalho, sendo corri queiros, na cultura da cana, os cortes nas mãos e nas pernas que os trabalhadores sofrem no manejo do podão de corte.

Se durante as safras de laranja e cana-de-açú car o mercado de trabalho volante apresenta maior estabilidade e formalidade dos contratos de trabalho, no período da entres safra estas condiçōes são muito alteradas. Os serviços passam a ser mais variados, de curta duração e instáveis e a assinatu ra das carteiras de trabalho tende a não mais ocorrer.

No Quadro 18, são apresentadas as atividades que os 50 trabalhadores entrevistados disseram ter durante o período de entressafra de cana e laranja, em relação à ocupa ção da safra. Observa-se que $21,5 \%$ das atividades referidas foram no setor urbano, especialmente na construção civil. E quase $80 \%$ das referencias foram de atividades desenvolvidas no setor rural, embora a maior partedos volantes tenha trabalha do na entressafra em outras culturas que não na cana e na la ranja.

Como o Quadro 18 indica, as atividades do setor urbano ocupam importante papel na oferta de emprego aos volan tes na entressafra. E este quadro refere-se somente à entres safra imediatamente anterior ao período da pesquisa. Se se considerar todos os anos de trabalho dos bóias-frias entrevis tados, 25 deles (50\%) declararam já terem tido emprego no se 


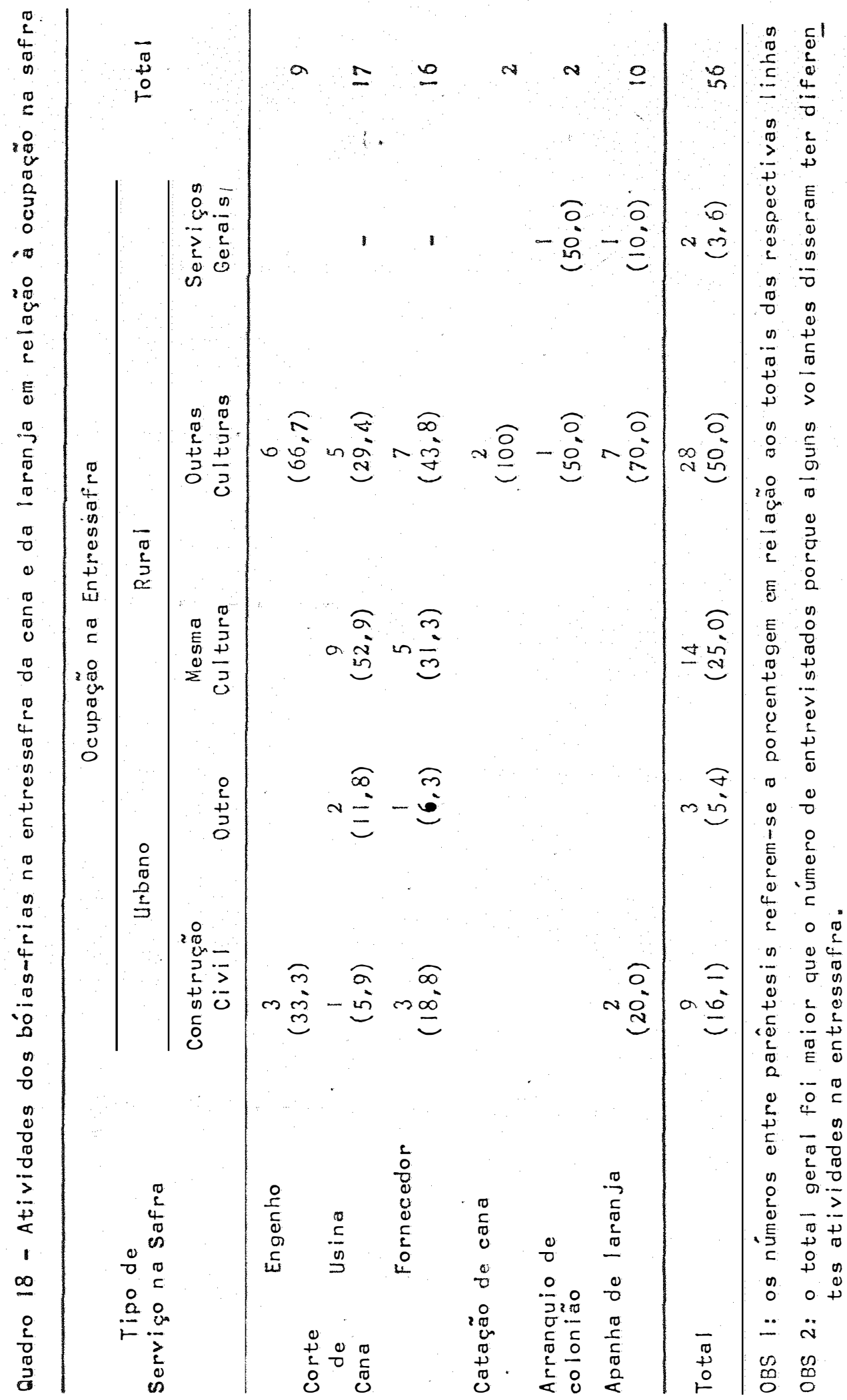


tor urbano.

As informaçöes obtidas através dos questioná rios de acompanhamento aos 11 bóias-frias selecionadós per mitem melhor qualificação das variações nas condições de traba Iho durante o ano. Estes questionários, realizados de agosto de 83 a agosto de 84, englobam a safra de cana e laranja de 83, a entressafra $83 / 84$ e a safra de 84 . Suas principais in formações são apresentadas nos Guadros 19, 20 e 21.

Dos volantes que inicialmente se dedicavam ao corte da cana em engenhos ou usinàs (Guadro 19), o trabalhador I, na entressafra, passou por fases de desemprego e trabalhou nas colheitas do amendoim e algodão, recebendo salários mais baixos do que os da safra, passando a ser agenciado pelo em preiteiro de mão-de-obra e a não mais contar com carteira 'de trabalho assinada. Na safra de 84 ele esteve empregado em duas usinas de açúcar e álcool, sendo que na segunda passou a morar nos barracões de trabalhadores da própria empresa. 0 trabalhador II esteve empregado durante todo o tempo junto ao mesmo empregador, tendo realizado um contrato na safra de 1983 como cortador de cana, unit contrato na entressafra como diaris ta (capina, plantio de cana, serviços gerais) e um novo contra to como cortador de cana em 1984, entremeados por 2 períodos de férias não remunerados. Durante todo o tempo foi contrata do diretamente pela usina e contou com carteira de trabalho as sinada, além do que seu nível salarial não caiu na entressafra, aliás foi até um pouco mais alto do que o da safra. O trabalha dor III,após o questionário inicial e o lo questionário de acompanhamentornão foi mais encontrado na pensão onde morava, sendo que na safra de 1983 sua contratação era feita através de firma empreiteira de mão-de-obra. 0 trabalhador IV, que 


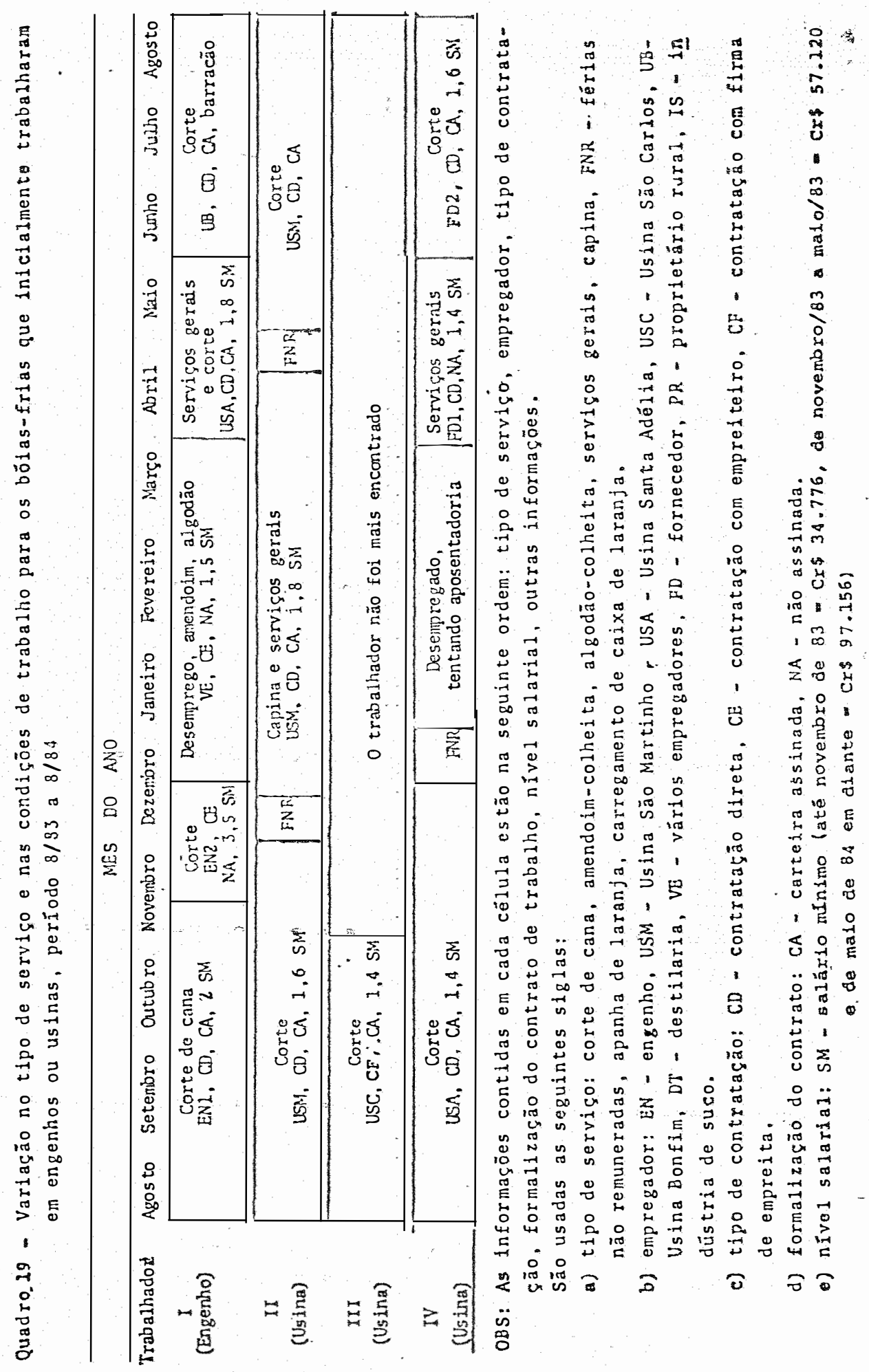


inicialmente apresentava condições muito semelhantes às do trabalhador II, posteriormente passou uma fase onde tentou a aposentadoria e, não tendo sucesso nessa tentativa,voltou a trabalhar na safra de 1984 em propriedades de fornecedores de cana ,

Dos bóias-frias que inicialmente trabalhavam no corte de cana em lavouras de fornecedores (Quadro 20), um de les (número II) ao findar a safra de 1983 esteve doente por 15 dias devido a esgotamento físico e. depois passou a trabalhar como guarda-noturno no meio urbano, conciliando esta atividade noturna com a de pedreiro durante parte do dia. Os outros três trabalhadores (números I, III e IV) apresentaram condições de trabalho bastante semelhantes entre si. Na safra de 1983 eram contratados diretamente para o corte da cana e tinham carteira de trabalho assinada. Na entressafra,dedicaram-se a serviços gerais, à colheita do amendoim e do algodão, entremeados por fases de desemprego. Nesta fase não contaram mais com cartei ra de trabalho assinada e muitas vezes foram agenciados por empreiteiros de mão-de-obra. O nível salarial caiu da safra para a entressafra, sendo que na época da colheita do amendoim e do algodão ocorreu certa melhora. Na safra de 1984, os tra balhadores III e IV voltaram a se dedicar ao corte de cana en quanto o I conseguiu emprego como diarista em uma destilaria de álcool, procurando fugir intencionalmente do desgaste físi co provocado pelo corte de cana.

No Quadro 21, observa-se que os 2 volantes co lhedores de laranja (o número I apanhador, o número II carrega dor de caixa) trabalharam sob as mesmas condições nas safras de 83 e 84 , sendo contratados diretamente por uma indústria de suco e contando com carteira de trabalho assinada. Na entres 


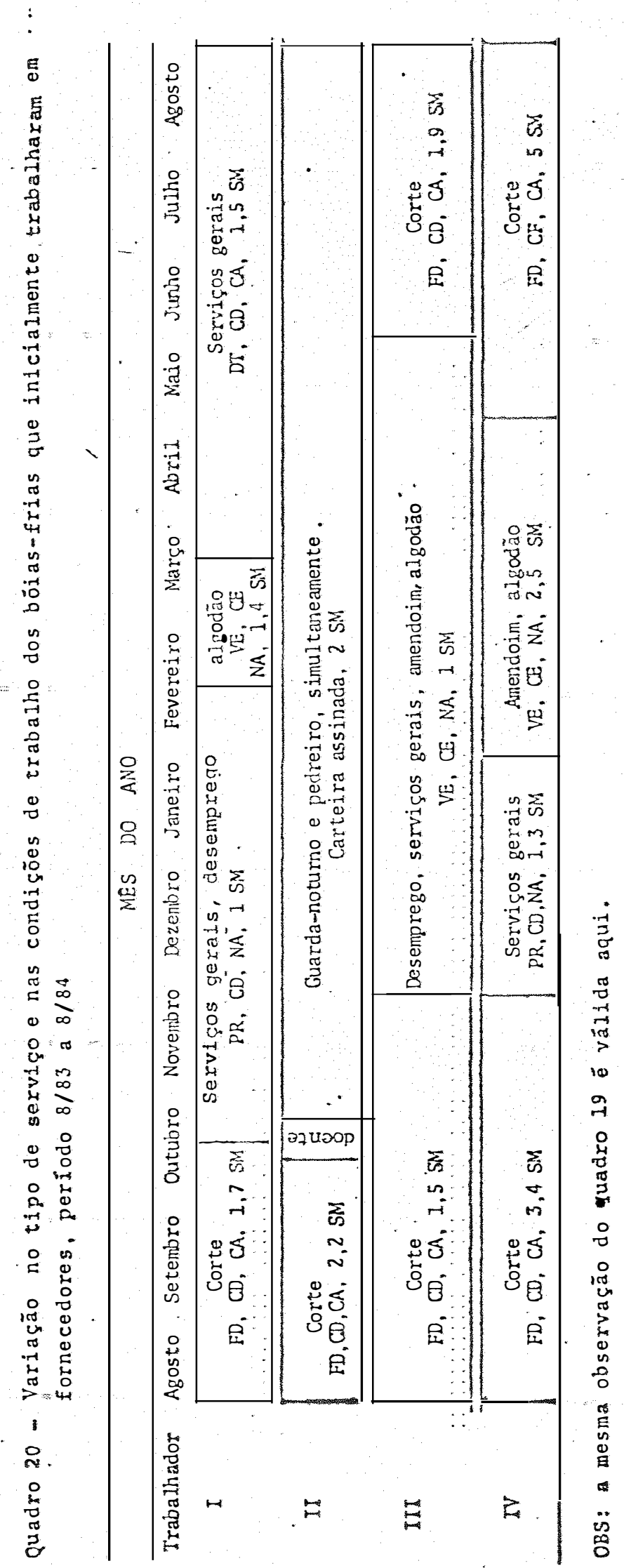


safra inicialmente também trabalharam sob as mesmas condições em serviços gerais e na colheita do amendoim, agenciados por empreiteiros e sem carteira de trabalho assinada. No final da entressafra, enquanto o primeiro trabalhava na cultura da ca na, o segundo passou a trabalhar autonomamente como carrocei ro, embora logo depois voltasse a trabalhar como volante. 0 trabalhador III é um alcóolatra que durante toda a fase de acompanhamento não se fixou em emprego nenhum, trabalhando pou cos dias/semana, normalmente em serviços menos qualificados co mo limpeza de brejos e arranquio de colonião. Sua situação o colocava no limiar da marginalidade social.

Os quadros analisados confirmam que, no geral, as condições de trabaltho vigentes na entressafra se caracteri zam pela instabilidade de emprego e informalidade dos vínculos empregatícios. Os empregos tornam-se mais escassos e os salá rios diminuem.

$$
\text { "Até a safra da laranja a vida é ruim, traba }
$$
lha-se 3 dias e para".

"As duas peruas que levam a gente para o servi ço vão lotadas. Na minha vão $18-20$ pessoas. Sempre tem gente implorando para trabalhar, pois estão passando necessidade. Ninguém consegue serviço nesta época da 'parada'".

A escassez de serviço faz com que alguns trabą Thadores planejem se deslocar ou mesmo se desloquem para ou tras regiões e Estados como Goiás, Minas Gerais, Paraná e até mesmo Pernambuco, à procura de maiores oportunidades de empre go. As experiências de deslocamento que se concretizam não trazem maiores benefícios aos trabalhadores, de maneira que 


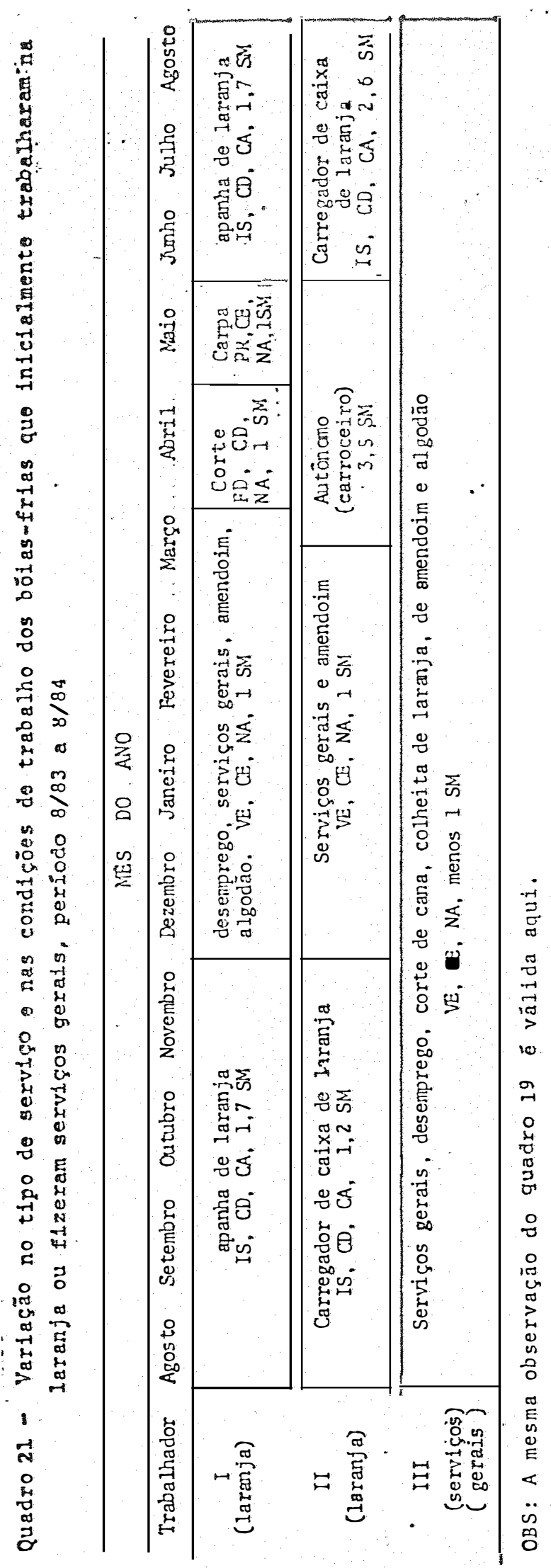


estes deslocamentos não se tornam sistemáticos:

Da mesma maneira que na safra, os serviços que são feitos na entressafra são pesados e esgotantes, ainda mais sendo realizados em épocas dé maior insolação e calor. Um dos serviços comumente realizado é o arranquio de colonião das la vouras de cana. Este serviço foi descrito assim por um volan te: "O 'peão' tem que entrar no meio das ruas de cana para ar rancar o colonjão. Faz muito calor e as folhas de cana cortam o rosto e as mãos. Além de arrancar o capim, o 'peão' deve le var a touceira até o carreador. Chega a molhar a camisa e a calça de suor. Têm companheiros que abandonam o serviço e voltam a pé para a casa". Na colheita do amendoim o trabalha dor tem que ficar o tempo inteiro agachado, o que provoca con $\underline{s}$ tantes dores nas costas. "O amendoim cansa mais que a laranja, pois o sol está judiando da gente e dá muito dor na costa".

$$
\text { A subestimação, ou melhor, o roubo na produção }
$$

obtida pelo bóia-fria continua existindo, seja no número de metros arrancados de amendoim, seja no número de arrobas colhi das de algodão ou em outras tarefas realizadas. Ainda mais que na entressafra o empreiteiro ou gato intermedia os pagamen tos e contribui para os descontos nos salários dos bóias-frias.

"No primeiro lugar onde eu 'panhava' algodão a balança roubava $4-5 \mathrm{~kg}$ por saco de $30 \mathrm{~kg}$. Depois que eu mudei de empreiteiro passei de 4 para 5 arrobas 'panhada'/dia, isto numa roça mais ruim".

* Evidentemente está se considerando neste comentário somente os bóias-frias moradores permanentes de Jaboticabal e não os "mineiros" que se caracterizam justamente por serem mi grantes sazonais. 
Uma tentativa de aproximação das principais condições de trabalho dos bóias-frias de Jaboticabal observa dos ao longo de um ano agrícola é apresentada no Quadro 22. ob serve-se que apesar das variações já comentadas entre a safra e a entressafra, durante todo o ano o nível salarial do volan te é extremamente baixo. O bóia-fria vende sua força de tra balho para realização de tarefas duras e desgastantes, nas quais não Łem nenhuma satisfação e com o objetivo único de con seguir obter o seu sustento, muitas vezes no limiar da fome. Sabe que o trabalho esgota o seu corpo e procura dosar o rítmo de trabalho, de maneira que "conseguindo fazer o dia" tenha maior horizonte de vida. tas vezes, sente-se obrigado a aumentar o rítmo de trabalho, apesar de suas deficiencias nutricionais e dos problemas que isto acarreta ao seu corpo e a sua saúde.

\subsection{Procedência, a Família e Condições de Vida}

A procedencia dos bóias-frias ainda é essencial mente rural. Como pode ser visto no Quadro 23, dos trabalhado res entrevistados, 36 (72\%) tiveram origem no meio rural, en quanto que 14 (28\%) nasceram no meio urbano. Destes últimos, 9 tiveram seus pais originados do meio rural e somente cinco

* Com um dos bóias-frias entrevistados trabalhavam no corte de cana seus dois filhos mais velhos. Eles haviam começado a trabalhar recentemente e tinham mais de 16 anos. 0 entre vistado disse que não pôs os filhos para trabalhar mais cê do, pois quando o trabalhador começa a trabalhar desde mu $\bar{i}$ to novo,com 20 anos "já está acabado e desiludido com a vai da"* 


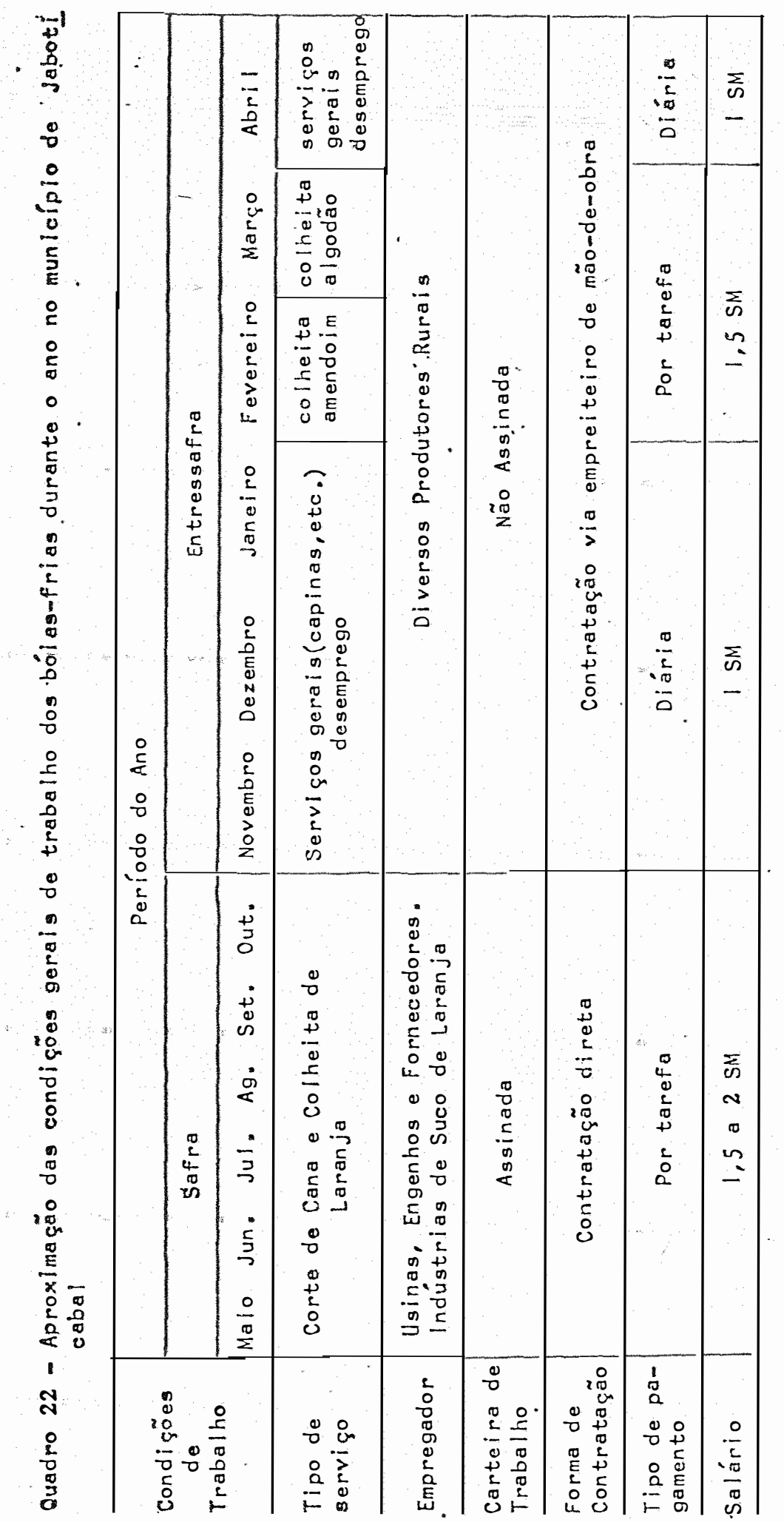


tiveram seus pais nascidos no meio urbano.

\begin{tabular}{lcc} 
Quadro 22 & $-\begin{array}{c}\text { Procedência dos bóias-frias } \\
\text { entrevistados }\end{array}$ \\
\hline Meio & Número & $\%$ \\
\hline Rural & 36 & 72 \\
Urbano & 14 & 28 \\
\hline Total & 50 & 100 \\
\hline
\end{tabular}

Dos 36 bóias-frias de origem rural, somente 2 $(5,6 \%)$ foram proprietários rurais, ambos na Região Nordeste do Brasil. Outros 9 (25\%) tiveram acesso à posse da terra como parceiros ou arrendatários. A maioria, entretanto, não teve acesso nem à posse nem à propriedade da terra, pois já eram as salariados quando moravam no setor rural. Estes eram em núme ro de 21 ou $58,3 \%$ do total de bóias-frias de origem rural (Qua dro 24).

Quadro 24 - Ocupação dos bóias-frias quando residentes no meio rural

\begin{tabular}{lcr}
\hline Ocupação & Número & $\%$ \\
\hline Não trabal hava & 4 & 11,1 \\
Empregado assal ariado & 21 & 58,3 \\
Parceiro & 4 & 11,1 \\
Arrendatário & 5 & 13,9 \\
Proprietário & 2 & 5,6 \\
\hline Total & 36 & 100,0 \\
\hline
\end{tabular}


Os dados revelam que na formação da categoria de bóias-frias o principal movimento foi a passagem dos assala riados rurais permanentes (colonos) para assalariados rurais temporários (bóias-frias). A expropriação de pequenos produto res teve menor importância na formação dos bóias-frias locais.

Atualmente mais um movimento contribui para a formação da categoria bóia-fria na região de Ribeirão Preto, que é a vinda de migrantes, especialmente de Minas Gerais, pa ra trabalharem na cultura da cana-de-açúcar. Destes migrantes, muitos dos quais pequenos proprietários em sua região de ori gem, uma parcela permanece definitivamente na região de desti no como assalariados temporários ou volantes.

Dos bóias-frias entrevistados, a grande maioria (43 ou 86\%) era do sexo masculino e a faixa de idade com maior incidencia de trabalhadores era a de 21 a 30 anos ( $36 \%$ dos en trevistados), vindo a seguir as faixas de 3 ! a 40 anos (22\%) e de 41 a 50 anos (16\%) (Quadro 25).

Como pode ser visto no Quadro 26, o tamanho mais encontrado de família foi aquele formado por 4 ou 5 pes soas, sendo que 18 ou $36 \%$ dos entrevistados se encontravam nes te caso. A seguir vinham as famílias com 2 ou 3 pessoas e de 6 a 8 pessoas, cada um dos casos com $24 \%$ das constatações. De modo geral, portanto, as famílias dos bóias-frias eram pouco numerosas sendo a prole composta, normalmente, de 2 a 3 filhos.

Geralmente, todas as pessoas aptas das famílias, inclusive os filhos maiores de 14 anos, trabalhavam fora de ca sa para complementação da renda familiar. Como o Quadro 27 re vela, a maior parte dos membros das famílias tinham a mesma ocupação do entrevistado, ou seja, eram também volantes, sendo 


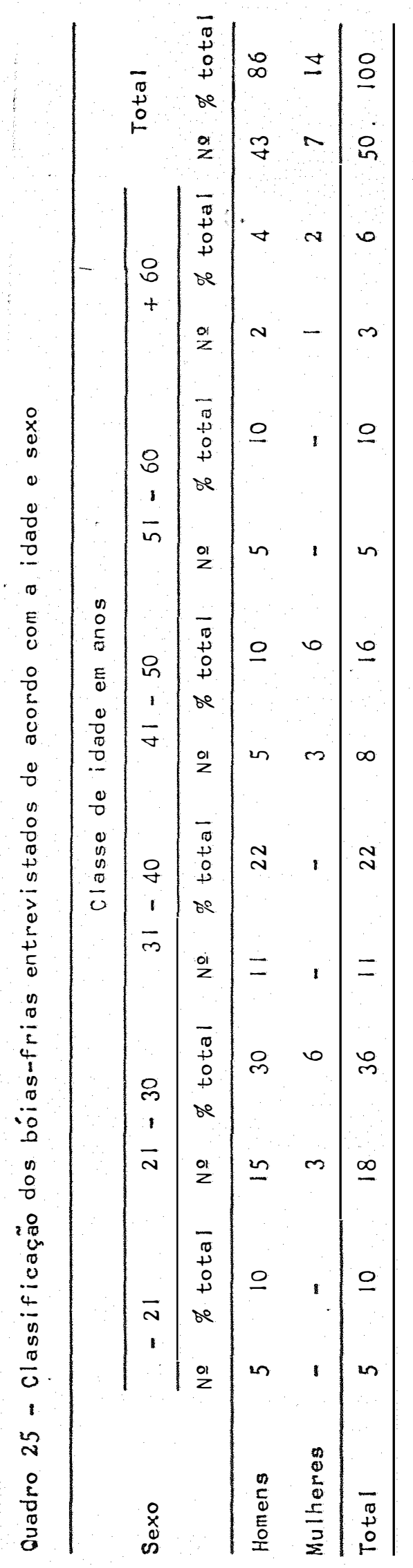


Quadro 26 - Número de membros da família dos bóias-frias entrevistados

\begin{tabular}{ccc}
$\begin{array}{c}\text { Membros da } \\
\text { família }\end{array}$ & Número & $\%$ \\
\hline 1 & 6 & 12 \\
$2-3$ & 12 & 24 \\
$4-5$ & 18 & 36 \\
$6-8$ & 12 & 24 \\
+8 & 2 & 4 \\
\hline Total & 50 & 100 \\
\hline
\end{tabular}

Quadro 27 - Tipo de trabalho dos membros da familia dos entrevistados

\begin{tabular}{lcc}
\hline $\begin{array}{l}\text { Tipo de } \\
\text { trabalho }\end{array}$ & Número & $\%$ \\
\hline Volante & 35 & 70 \\
Doméstica & 10 & 20 \\
Outros & 5 & 10 \\
\hline Total & 50 & 100 \\
\hline
\end{tabular}

que em $70 \%$ dos casos foi observada esta situação. Vinha a se guir o emprego como doméstica constatado em $20 \%$ das respostas. Os outros serviços citados foram balconista, guarda-noturno e ceramista. O bóia-fria e sua família trabalham em serviços de pouca ou nenhuma qualificação e que são mal remunerados, sendo que o fato dos filhos reproduzirem a situação dos pais, ou se ja, trabalharem também como volantes, revela as pequenas possi 
bilidades de ascensão social desta categoria de trabalhadores. Apesar de várias pessoas trabalharem na família, o nível geral de renda familiar constatado entre os bóiasfrias era baixo. A renda fámiliar mais comum era a de 2 a 3 salários mínimos, verificada em 18 ou $37,5 \%$ das famílias. A renda de 3 a 5 salários mínimos foi observada em $29,2 \%$ dos ca sos e de 1 a 2 salários mínimos em $20,8 \%$ das famílias. Em cer ca de $65 \%$ dos casos observou-se que a renda familiar dos entre vistados estava abaixo de 3 salários mínimos e em aproximada mente $94 \%$ abaixo de 5 salários mínimos. Somente cerca de $6 \%$ dos entrevistados apresentavam renda familiar de 5 a 8 salá rios mínimos e nenhum acima disto (Quadro 28).

Quadro 28 - Renda familiar dos bóiaś́frias entrevistados

\begin{tabular}{rccc}
\hline Nível de renda (SM) & Número & $\%$ & $\%$ acumulada \\
\hline até 1 & 3 & 6,3 & 6,3 \\
$1-2$ & 10 & 20,8 & 27,1 \\
$2-3$ & 18 & 37,5 & 64,6 \\
$3-5$ & 14 & 29,2 & 93,8 \\
$5-8$ & 3 & 6,3 & 100,0 \\
\hline Total & 48 & 100,0 & 100,0 \\
\hline
\end{tabular}

OBS: 2 informações apresentavam inconsistência

Os níveis de renda apresentados no referido qua dro foram constatados no período da safra de cana-de-açúcar e de laranja. Na entressafra a renda familiar tende a cair, por que os salários caem e porque diminuem as oportunidades de em 
prego no meio rural, fazendo com que os menores e as mulheres deixem de trabalhar ou se empreguem como domésticas no meio ur bano.

É com os rendimentos obtidos na safra e, espe cialmente, com os acertos trabalhistas em seu final, que as fa mílias conseguem adquirir bens duráveis como eletrodomésticos e móveis, a lém de guardarem alguma economia para os meses de entressafra. Não raro, no período de entressafra, os salários recebidos e as economias guardadas não são suficientes para o sustento da família, fazendo com que os trabalhadores vendam os bens adquiridos anteriormente.

"Trabalhei uma semana e tirei Cr\$6.000,00. Pre cisei vender mesa e cadeiras".

$$
\text { Quanto ao grau de instrução, constatou-se (Qua }
$$
dro 29) que $18(36 \%)$ dos entrevistados eram analfabetos, 6 (12\%) só assinavam o nome e 17 (34\%) não tinham completado o curso primário. Assim, $82 \%$ dos bóias-frias entrevistados ti nham no máximo primário incompleto " O agravante desta situa ção é que os pais têm dificuldade de manterem seus filthos na escola, pois saem para o trabalho de madrugada, antes do horá rio de enviarem as crianças para a aula, além do que as crian ças mais velhas têm obrigações domésticas. Os filhos tendem a reproduzir desta forma, as condições de analfabetismo ou semianalfabetismo dos pais.

Pelo Quadro 30 , observa-se que $42 \%$ dos bóiasfrias entrevistados moravam em casa alugada, vindo a seguir as casas próprias ( $34 \%$ das observações). Estas, muitas vezes, fo ram construídas pelos volantes nos domingos e folgas do servi ço. Geralmente não possuem pintura nem vidraças, além do que 
Quadro 29 - Grau de instrução dos bóias-frias entrevistados

\begin{tabular}{lccc} 
Grau de instrução & Número & $\%$ & \% acumulada \\
\hline Analfabeto & 18 & 36 & 36 \\
Só assina o nome & 6 & 12 & 48 \\
Primário incompleto & 17 & 34 & 82 \\
Primário completo & 4 & 8 & 90 \\
Ginásio incompleto & 4 & 8 & 98 \\
Ginário completo & 1 & 2 & 100 \\
\hline Total & 50 & 100 & 100 \\
\hline
\end{tabular}

apresentam pequeno número de cômodos, por morador. Foi comum constatar-se casos em que o casal e os filhos dormiam no mesmo quarto* Existem também os cortiços e pensões dos solteiros,cä racterizados pelo amontoamento de pessoas e pelas precárias condições de higiene.

Quadro 30 - Tipo de moradia dos bóiasfrias entrevistados

\begin{tabular}{lcc}
\hline Tipo de moradia & Número & $\%$ \\
\hline Própria & 17 & 34 \\
Financiada & 5 & 10 \\
Alugada & 21 & 42 \\
Pensão & 7 & 14 \\
\hline Total & 50 & 100 \\
\hline
\end{tabular}

Na safra, devido ao aumento da população pela 
vinda de trabalhadores de outras regiões, as condições precá rias de habitação tendem a se agravar.

As moradias dos bóias-frias se localizam na pe. riferia das cidades normalmente em ruas não pavimentadas (90\% dos casos). Em reláąão aos outros equipamentos urbanos a si tuação era melhor, com $80 \%$ das moradias contando com instala ção sanitária, $98 \%$ com luz elétrica e $86 \%$ comágua encanada (Quadro 31).

Quadro 31 - Equipamentos urbanos nas moradias dos bóias-frias entrevistados

Tipo de equipamen to

Possui Não Possui

Número $\%$ Número $\%$

Instalção sanitária Luž elétrica Água encanada Ruas pavimentadas
40

49

43 5
80

98

86

10
10

I

7

45
$\%$

20 50 50

50

14

90

Quanto à saúde dos bóias-frias, a pesquisa não permitiu que se obtivessem informações mais precisas e rigoro sas. Visivelmente, as crianças apresentavam problemas de sub nutrição e verminose. Os adultos comumente relataram proble mas de lesões resultadas de acidentes de trabalho, bem como problemas musculares, de esgotamento físico e estomacais. agravante é que a assistência médica e hospitalar de que dis põem é precária, principalmente quanto à qualidade do atendi mento médico. 
Contudo é a alimentação, ou melhor, a fome que revela de maneira marcante a precariedade de existência do bóia-fria.

"Eu tenho medo de faltar serviço e passar fome" A causa deste medo muitas vezes se concretiza.

Durante a safra de cana e laranja a falta total de comida dificilmente chega a ocorrer. Obóia-fria consegue levar sempre arroz e feijão, um pedaço pequeno de carne, sardi nha ou linguiça normalmente e alguma outra mistura. Uma ali mentação pobre em proteínas que mantém o trabalhador subnutri do.

Os problemas que a subnutrição causa ao rendi mento do trabalhador têm começado a preocupar, de certa forma, algumas usinas da região. Conhecem-se dois exemplos em que recentemente começaram a ser distribuídas refeições quentes e balanceadas e um outro exemplo em que começou a ser distribuído leite de soja aos trabalhadores, na tentativa de aumentar as toneladas de cana cortadas diariamente.

Na entressafra a fome deixa de ser apenas quali tativa, mas passa a ser, muitas vezes, quantitativa - falta co mida " lsto se evidencia em vários relatos de diferentes traba Ihadores.

"Eu não tenho vergonha de dizer, no Natal minha mistura foi abóbora". "A comida está pior do que antes, já não compro nem carne mais, só levo arroz e feijão". De um tra balhador que carregava caixas de laranja na safra.

"Tem dia que eu levo só pão pará a roça. Para amanhã eu tenho um pouco de arroz para levar, foi minha tia que deu a comida". Essa trabalhadora que na safra apanhava la 
ranja já há dois meses não contava com feijão em sua marmi ta.

Aliás, a saída do fei jão da dieta normal . dos trabalhadores foi uma tendência generalizada observada na en tressafra $83 / 84$.

"Em casa está sem sal, café, óleo. Hoje preci sei pegar sal emprestado do cunhado. A mulher precisou tirar Cr\$1 10.000 adiantado para comprar arroz e óleo que estão aca bando. Vou sem feijão para roça, não tenho dinheiro para com prar. Levo arroz e ovo ou linguiça (um pedaço). Quando chego na roça, na hora de comer, eu vou para um canto com vergonha dos outros companheiros, para que não vejam que nem feijão es tou levando. Têm companheiros na mesma situação, alguns ficam até 5 dias sem comer". De um trabalhador que na safra cortava cana.

Trabalhar para se alimentar passa a ser o obje tivo imediato e imprescindível para o bóia-fria. "Se a gente ganha para comer deve dar Graças a Deus".

Nesta situação de miserabilidade a bebida alcó olica, a pinga,é consumida corriqueiramente, mesmo porque ela é uma fonte extra de energia para o trabalhador. Entre os en trevistados havia um alcóolatra que não trabalhava mais de dois dias por semana, mudando constantemente de emprego . Havia também vários outros trabalhadores que sempre se mostravam em briagados nas entrevistas, embora apresentassem um rítmo nor mal de trabalho.

De maneira geral, portanto, o bóia-fria vive sob condições de vida precárias, com a fome sendo ameaça constante no seu dia-a-dia. E o trabalhador percebe em sua realidade 
poucas possibilidades de ascender socialmente; sua perspectiva imediata se resume, muitas vezes, em arrumar emprego fixo me nos duro no meio urbano ou conseguir arrumar emprego fixo nas usinas. No período em que durou a pesquisa, um bóia-fria con seguiu emprego fixo no setor urbano como guarda-noturno, tendo ainda que realizar alguns serviços durante o dia como servente de pedreiro para complementar o seu ganho. Outro bóia-fria passou a ser carroceiro, embora meses depois voltasse a traba thar como volante na colheita da Iaranja.

As condições de vida são precárias e as expectą tivas pequenas. "Se fosse para nascer hoje eu preferia nascer morto. A fome que passei, as necessidades que eu precisei..." 
Em seu livro Expropriação e Violência, MARTINS (1980:12) afirma que: "As grandes inquietações no campo, os conflitos cada vez mais numerosos são determinados pelo proces so de expropriação da terra. A exploração do trabalhador é um problema que aparece num segundo plano, muitas vezes embutida na propriedade e por ela escamoteada. É exatamente o inverso do que acontece nas grandes cidades, nas indústrias. Aí, nos confrontos entre as classes sociais, surge intensa e primeira mente o problema de exploração do trabalhador pelo capital, pe lo patrão". (Grifado no original).

$$
\text { Esta afirmação merece ser reavaliada face }
$$
aos recentes movimentos sociais acontecidos na agricultura bra sileira durante o ano de 1984. O mais abrangente foi o movi 
mento dos cortadores de cana que no primeiro semestre atingiu Estados do Centro-Sul do País como Goiás, São Paulo e Rio de Janeiro. No segundo semestre foram os cortadores de cana do Nordeste, especialmente em Pernambuco, que se mobilizaram e realizaram movimentos reivindicatórios. Enquanto que no pri meiro caso destacou-se o ineditismo do movimento, pelo menos em sua abrangência e em seu grau de violência, no segundo os trabalhadores mantiveram a já tradicional luta anual com os proprietários das lavouras de cana do Nordeste.

Além dos cortadores de cana, outras categorias de trabalhadores também realizaram amplos movimentos reivindi catórios, especialmente os collhedores de café e os apanhadores de Iaranja do Estado de São Paulo.

Estes movimentos, onde a greve foi instrumento de pressão generalizado e que envolveram milhares de trabalha dores assalariados, especialmente bóias-frias, todos eles se caracterizaram pelas reivindicações por salários mais altos e melhores condições de trabalho. Foram lutas de assalariados contra a exploração do trabalho pelo capital.

O município de Jaboticabal e seus trabalhadores foram atingidos por dois destes movimentos, o dos cortadores de cana e o dos apanhadores de laranja. Ambos se iniciaram em municípios vizinhos a Jaboticabal, o primeiro em Guariba e o segundo em Bebedouro, e tenderam a se espraiar por toda a re gião canavieira e citrícola.

Até então os movimentos reivindicatórios dos bóias-frias locais não costumavam abranger mais do que a turma de um caminhão, caracterizando-se por serem esparsos e ocasio 
nais. Já em Guariba e Bebedouro toda uma categoria social ten deu a se mobilizar, dando maior amplitude e força à luta dos bóias-frias por melhores condições de trabalho. No restante deste capítulo tenta-se explicar o porquê destes dois momen tos, ou seja, porque até Guariba e Bebedouro os volantes apre sentavam pequeno poder de mobilização e reivindicação e, após, este poder foi bruscamente alterado e reforçado.

5.1. As Reivindicações e as Dificuldades de Mobilização dos Bóias-Frias

A literatura tem considerado que o trabalhador volante apresenta dois tipos básicos de reivindicação: um rela cionado àaspiração pela posse da terra, outro direcionado pa. ra melhores condições de trabalho.

Através dos 50 questionários iniciais tentou-se captar quais as reivindicações dos bóias-frias de Jaboticabal. Quando aos trabalhadores foi feita a específica pergunta se gostariam de voltar a morar na roça, muitos responderam que sim, especialmente como proprietários da terra, "tocando lavou ra por conta". Aspiração por uma situação que a maioria dos trabalhadores jamais vivenciou. Duas justificativas básicas apresentadas pelos trabalhadores para o desejo de voltarem a morar no meio rural foram:

"Na roça tem mais fartura de coisas, na cidade é tudo na base do dinheiro".

"Na roça não paga aluguel, luz', água".

Outros trabalhadores responderam negativamente 
à pergunta retro explicitada. Esses não viam possibilidade de terem acesso efetivo à terra e diziam que os fazendeiros res tringem o plantio e a criação de animais.

"Na cidade é mais fácil. Se o cara vai para a roça não pode plantar mais nada. Ninguém deixa plantar".

"Na fazenda não dá nada, nem dinheiro, nem ter ra".

Quando aos bóias-frias foi feita uma pergunta mais geral sobre o que eles desejavam que melhorasse em sua vi da, quais suas principais aspirações, já então o desejo pela posse da terra quase não mais apareceu nas respostas. As aspi rações básicas verbalizadas pelos trabalhadores referiam-se a melhorias no nível salarial e nas condições de trabalho.

"Gostaria de pegar um serviço bem pago".

"Um melhor saĺário".

"Um meio de transporte mais seguro".

"Ganhar um dinheirinho que desse pelo menos pa ra comer bem".

"É melhor ganhar mais do que ter um pedaço de terra",

O desejo de emprego fixo, especialmente na cida de, foi comumente citado.

"Gostaria de um emprego mais garantido".

"Arrumar emprego na cidade, livre do caminhão".

Também expressaram aspiração de empregos menos esgotantes e mais valorizados socialmente.

"Preferia um serviço melhor que o corte de cana, onde pudesse aprender alguma coisa". 
"Gostaria de trabalhar sem sofrer tanto".

"Ser mais valorizado, pois sou um trabalhador braçal e têm pessoas que não fazem esforço (serviço de escrittó rio) e ganham muito mais"...

o acesso à terra é algo vago, distante e sem muito sentido na percepção dos trabalhadores volantes. Suas aspirações imediatas e para as quais conseguem algum nível de mobilização, são aspirações de assalariados, por maiores salá rios e melhor qualidade de enprego.

Isto se evidenciava em reuniões de bóias-frias promovidas pela Comissão Pastoral da Terra (CPT). Sempre que os coordenadores propunham discussões sobre a posse da terra e mesmo quando tentaram integrar os bóias-frias na Campanha Na cional pela Reforma Agrária, a motivação dos trabalhadores era pequena, com as discussões no final se direcionando para pro blemas relacionados ao custo de vida e as condições de traba Iho, especialmente o sistema de corte de cana por 7 ruas.

o bóia-fria local não resultou, no geral, de processo de expropriação da terra. Ao que tudo indica,a maior parte do contingente de bóias-frias em Jaboticabal foi formada por ex-assalariados rurais que perderamas condições de emprego permanente, normalmente associada à produção de bens de subsis tência no campo, e se transformaram em trabalhadores rurais temporários residentes na cidade. De modo geral, não são pe quenos produtores expropriados, já na sua origem são assalaria dos, sendo que sua consciência foi-se moldando nesta situação, daí o predomínio das reivindicações por salários e melhores condições de trabalho. 
As precárias condições de trabalho e vida dos bóias-frias, com a fome sendo uma ameaça constante, tornam o trabalhador extremamente insatisfeito e desejoso de mudanças imediatas em sua situação. Sabem que precisam se organizar e reivindicar conjuntamente.

"Uni ão com os companheiros é bom porque dá mais força para reclamar. Sózinho ninguém pode reclamar".

"A turma toda se negou a cortar 7 ruas e o pa trão voltou atrás. Não deixamos também que entrasse o pagamen to por metro em vez de tonelada".

Entretanto, são os próprios trabalhadores que reconhecem a falta de união entre eles.

"Os gatos e o patrão sobem em cima de nós por que nós não temos uma união boa".

"Os 'cativados' não vão atrás de lei. Se todo mundo fosse junto seria melhor. Os pobres não têm união, um prejudica o outro. Se fosse unido seria bem melhor".

"O problema do trabalhador é que tem muito que é desencontrado um com outro. Greve não vai para frente, fal ta uni ão".

"Ele se vê apertado, se não for pelo que o pạ trão oferece passa fome. Antes pingado do que a fonte secar".

"A preocupação com saúde e a 'brabeza' do pes soal é só longe do feitor. O homem chega e tudo se acaba. 0 problema é o desemprego que gera a falta de união da turma. A barriga dói e aí ninguém é mais macho para pedir nada".

Do ponto de vista institucional aparecem barrei 
ras ao encaminhamento das reivindicações dos volantes. São constantes as reclamações quanto à morosidade e ineficácia da Justiça do Trabalho o que, em última análise, acaba favorecen do a classe empregadora.

"O pöbre não tem dinheiro, não pode comprar a lei. O patrão chega e compra a lei". dois anos para receber"

Mesmo o Sindicato de Trabalhadores Rurais não aparece para o bóia-fria como um órgão de organização, mobili zação e de encaminhamento de suas reivindicações. Como o Qua dro 23 revela, a utilização do Sindicato pelos bóias-frias era direcionada maciçamente para assistência médica ou odontológi ca. Muitos trabalhadores chegavam a confundir o Sindicato com o Funrural, revelando o caráter meramente assistencialista que assume a entidade.

Quadro 23 - Filiação e utilização do Sindicato de Trabalhado res Rurais pelos boias-frias entrevistados

\begin{tabular}{|c|c|c|c|c|c|c|c|c|}
\hline \multirow{3}{*}{ Fili ação } & \multirow[b]{3}{*}{ № } & \multirow[b]{3}{*}{$\%$} & \multicolumn{6}{|c|}{ Utilização } \\
\hline & & & \multicolumn{2}{|c|}{ médica } & \multicolumn{2}{|c|}{ trabalhista } & \multicolumn{2}{|c|}{ não utiliza } \\
\hline & & & № & $\%$ & № & $\%$ & No & $\%$ \\
\hline Sim & 21 & 42 & 16 & 76,2 & 2 & 9,5 & 5 & 23,8 \\
\hline Não & 26 & 52 & 10 & 38,5 & 2 & 7.7 & 15 & 57.7 \\
\hline Já foi & 3 & 6 & 2 & 66,7 & 1 & 33,3 & - & - \\
\hline Total & 50 & 100 & 28 & 56,0 & 5 & 10,0 & 20 & 40,0 \\
\hline
\end{tabular}


Poucos trabalhadores utilizavam o Sindicato pa ra reclamações trabalhistas e, nestes casos, existia a preocu pação de ficarem "marcados" pelos empreiteiros e empregadores e terem dificuldades de arrumar emprego.

"Sindicato não resolve nada, pois a gente fica mal visto, os fazendeiros queimam a gente. A verdade é que o patrão faz o que quer e nós não fazemos nada. Uma vez levei ferro com o sindicato. Não recebi e minha carteira ficou su ja" .

Nenhum dos 50 trabalhadores entrevistados reve lou perceber o Sindicato de Trabalhadores Rurais como um órgão de organização e mobilização dos bóias-frias, um órgão que di recione as reivindicações dos trabalhadores, que organize movi mentos grevistas, por exemplo. O Sindicato é visto como outra entidade burocrática qualquer, como a Delegacia da Justiça do Trabalho ou como o Posto do Funrural, que presta alguns servi ços aos trabalhadores, mas sobre o qual o trabalhador não tem nenhum controle. Uma entidade que não lhes pertence, enfim.

E na própria situação vivenciada pelo bóia-fria dois fatos dificultam sua organização como classe social e im pedem um poder reivindicatório mais eficaz e amplo. Em primeí ro lugar, o mercado de trabalho volante tende a se caracteri zar pela existência de uma superpopulação relativa, estimulan do a ocorrencia de acirrada competitividade entre os trabalha dores. Isto se evidencia especialmente no período da entressa fra da cana e da laranja, quando diminuem as oportunidades de emprego. Nesta situação qualquer tentativa mais śéria de rei vindicação pode significar a.perda de emprego para o trabalha dor, que é facilmente substituído por outro. E, posto que os 
bóias-frias precisam de imediato de seus salários para poderem sobreviver. - é comum o volante dizer que "trabalho hoje para comer amanhã" - isto acirra ainda mais a competitividade entre os trabalhadores e obriga-os, a se sujeitarem a qualquer tipo de trabalho.

Outro fator que dificulta a organização do bóiafria é o caráter disperso e irregular de seu trabalho, observa do especialmente na entressafra. Nesta fase o trabalhador mu da constantemente de serviço e de empregador, com os trabalha dores não ficando juntos muito tempo. No máximo ocorre conso l idação ou organização de determinada turma de um caminhão de empreiťiro. A organização dos trabalhadores torna-se difícil, pois existem os que colhem amendoim, os que colhem algodão, os que capinam, os que realizam a catação do milho, os que estão desempregados, sendo que 1 ou 2 semanas depois os tipos de ser viço dos bóias-frias podem estar totalmente alterados.

Durante a safra, quando a necessidade de traba lhadores é maior, o que contribuiria para diminuir a competiti vidade entre os trabalhadores, este fato é compensado, até cer to ponto, pela vinda de migrantes sazonais, os "mineiros", para fazerem a safra de cana $\frac{*}{2}$

Além de tenderem a aumentar a competitividade en tre os trabalhadores, parcela dos "mineiros" é mantida no inte rior das propriedades, alojada em barracões, permitindo maior controle sobre a mão-de-obra por parte do empregador no ajuste

* Na verdade é impossível determinar o real alcance deste fa to, pois não há meios de se estimar a participação dos "mi neiros" no número total de cortadores de cana. 
de jornada de trabalho, nos dias trabalhados na semana, na de signação das tarefas a serem realizadas e mesmo nos salários estipulados para cada tarefa. Entre os bóias-frias locais, os "mineiros" são considerados como aqueles que se sujeitam às piores condições de trabalho e aos piores salárics.

"Trabalham por qualquer preço e enchem os cami nhões, não sobrando lugar nos caminhões para nós, às vezes".

"Quando começou a aparecer os mineiros, os bóias-frias da cidade não gostavam, porque os mineiros vêm pra ganhar, não reivindicando. Há uns $10 / 15$ anos atrás, antes dos mineiros quando aparecia 'cana pé-rolo' (cana de primeiro cor te, muito densa e entrelaçada, difícil de ser cortada) exi gia-se preço de corte de cana crua; caso não aceitassem este preço, não trabalhavam, se a cana não queimava bem, não iam. Se era necessário trabalhar domingo, cobravam em dobro, se não pagassem, não trabalhavam. Agora com os mineiros, se a usina falava para eles trabalharem domingo e eles não iam, colocavam os mineiros. Atrapalhou portanto as greves, porque se a gente não faz, os mineiros faz. Os mineiros trabalham mesmo!". Fala de um bóia-fria citado em SEADE (1983:34).

O isolamento dos "mineiros" nos barracões, se parados de outros trabalhadores volantes da cidade, contribui para a desorganização e desmobilização dos cortadores de canade-açúcar. Entretanto, a sujeição ou a docilidade dos "minei ros" em aceitarem as piores tarefas deve ser melhor qualifica da. Na safra de 1983, uma única usina da região não conseguiu implantar o sistema de 7 ruas, justamente aquela que utiliza, como grosso do contingente de cortadores de cana, os "minei ros", mantidos em seus barracões. Estes trabalhadores não 
aceitaram a subsitituição das 5 ruas.

Um fator que diferencia os "mineiros" dos traba Thadores locais é o fato deles ficarem alojados no interior das unidades produtivas " Outra fator é que muitos "mineiros" são pequenos produtóres em sua região de origem e que se assa lariam temporariamente, enquanto os bóias-frias locais encon tram-se totalmente proletarizados. A permanência dos "minei ros" na região de cana é temporária, não possibilitando que eles estabeleçam maiores vínculos com o meio urbano. Além dis so, sua manutenção não depende exclusivamente do trabalho assa lariado, mas também é garantida, em parte, por cultivos de sub sistência em sua região de origem. Assim, poder-se-ia supor que os "mineiros" constituiriam uma categoria à parte, dife renciada em termos polícicos do bóia-fria. Entretanto, há mui to pouco subsídio para se avançar neste ponto e, preliminarmen te, poder-se-ia confrontar esta suposição com o fato de que a pequena produção do "mineiro" talvez lhe garanta uma renda tão baixa que eles estariam na eminência de se tornarem assala riados. Muitos "mineiros" que vêm para a safra de cana acabam ficando definitivamente na região.

De qualquer maneira, a maior necessidade de mão-de-obra nas safras de cana e laranja e a grande vinculação da produção agrícola à produção industrial nesta fase (as moen das precisam de fornecimento contínuo de cana cortada e laran ja colhida) reforçam, neste período, o poder de reivindicação e de mobilização dos trabalhadores perante seus empregado res. E, diferentemente da entressafra, o mercado de trabalho volante mostra-se mais organizado na safra, com o trabalhador passando a contar com maior estabilidade de emprego e formali 
dade nos vínculos empregatícios. Não por coincidência, foi justamente na fase da safra de cana e de laranja que ocorreram os movimentos de Guariba e Bebedouro*

\section{$5 \times 2$. Os Movimentos de Guariba e Bebedouro}

Como já discutido anteriormente, uma das carac terísticas básicas tanto do movimento dos bóias-frias de Guari ba quanto do de Bebedouro foi a sua abrangência, com a partici pação de grande número de trabalhadores, envólvendo praticamen te toda a categoria de bóias-frias das duas cidades, em um pri meiro instante e de outras cidades da região, em um segundo mo mento.

- grande número de trabalhadores envolvidos es tá relacionado com a expansão da cultura da cana-de-açúcar em Guariba e da laranja em Bebedouro, tornando suas agriculturas praticamente monocultoras dos volantes locais passe a ser ou cortador de cana, no primei ro caso, ou apanhador de laranja, no segundo. Ao mesmo tempo que o crescimento da área de cana e laranja dá uma identidade própria à agricultura destes dois municípios, assim como a de outros municípios da região - são os municípios canavieiros ou os municípios citrícolas -, ele faz com que o bóia-fria passe

*/ Em 1980 a cultura da cana-de-açúcar ocupava $73 \%$ da área dos estabelecimentos e $83 \%$ da área de lavouras no município de Guariba, enquanto que a laranja ocupava $56 \%$ da área dos es tabelecimentos e $79 \%$ da área de lavouras no município de Bebedouro (FIBGE, 1980). 
a se identificar apenas como cortador de cana-de-açúcar ou co mo apanhador de laranja. Para o bóia-fria sobram poucas ou tras oportunidades de emprego no campo, mesmo porque a expan são da cana-de-açúcar e da laranja expulsa outras atividades agrícolas, assim como se mostram reduzidas as oportunidades de emprego no setor urbano, inclusive em centros maiores, onde o nível de desemprego tem se mostrado elevado nos últimos anos.

Embora os bóias-frias muitas vezes revelem dese jos de mudar de emprego, de deixarem de ser cortadores de cana ou apanhadores de laranja, as perspectivas para que isso acon teça são pequenas. A sua condição não é temporária, mas sim definitiva, e precária. Seus problemas, os baixos salários, a precariedade de seu nível de vida, têm que ser solucionados na situação de cortadores de cana ou de apanhadores de laranja e suas reivindicações e mobilizações se posicionam contra os em presários da cana e da laranja.

"Contraditóriamente, porém, vão surgindo na re gião as pré-condições para a organização dessa classe trabalhạ dora 0 fato da região transformar-se em monocultora garanteThe uma identidade econômica que tem, como contraponto, a emer gência da identidade dos próprios bóias-frias, enquanto catego ria de trabalhadores. A possibilidade de, todos os anos, tra balharem na safra vai possibilitando a auto-identificação como trabalhadores da cana. Vai permitindo-lhes substituir as ve lhas fantasias de trabalho na indústria ou davolta à terra,

*) Em anos recentes tem-se observado a afluência de ex-metalúr gicos desempregados e outros ex-trabalhadores urbanos para os serviços nas culturas da cana-de-açúcar e laranja. 
por essa dura realidade. Realidade que, uma vez enfrentada, passa a ser avaliada e criticada pelos mesmos. Passa a ser percebida como passível e necessitada de modificações" (D'INCAO, 1984:31).

A identificação dos bóias-frias como trabalhado res da cana ou da laranja é especialmente verificada na fase de colheita. Neste período, diferentemente da entressafra, as operações agrícolas são pouco variadas, limitando-se pratica mente ao corte da cana ou a apanha da laranja. Em consequen cia, um contingente maciço de trabalhadores passa a ter idên ticos problemas e as mesmas reivindicações, o que, ao menos po tencialmente, aumenta o poder de pressão dos bóias-frias sobre a classe patronal.

É também na safra que o mercado de volantes se mostra mais organizado, com os trabalhadores sendo contratados diretamente pelos empresários, sem a intermediação de empreí teiros, por período normalmente de 6 meses, em alguns casos permanentemente e contando com vínculos formais de emprego. Esta maior organização, como já visto anteriormente, decorre de necessidades próprias das agroindústrias sucro-alcooleira e citrícóla. Para o trabalhador, esta situação significa maior garantia de emprego ou, dito de outra forma, menores chances de ficar desempregado, o que também contribui para fortalecer seu poder de pressão perante o empresário.

5.2 .1 . A Revolta de Guariba

Uma das causas imediatas do movimento dosbóias- 
frias de Guariba, ocorrido no início da safra de 1984, foi a implantação do sistema de corte de cana por 7 ruas a partir da safra de 1983. A medida inicialmente foi adotada pelas usinas, as quais passaram a incentivar seus fornecedores de cana para que fizessem o mesmo. Com as 7 ruas as usinas são beneficia das tanto em termos de rendimento agrícola, quanto industrial, enquanto que os fornecedores se beneficiam somente dos rendi mentos agrícolas.

Já na safra de 1983 ocorreu forte reação dos trabalhadores contra as 7 ruas. Foram observados movimentos esparsos de trabalhadores, greves localizadas, onde se exigia a volta do sistema de 5 ruas. Junto à maior parte dos fornecedo res os trabalhadores conseguiram sucesso em suas reivindica ções, entretanto as usinas, com exceção de uma delas, mantive ram as 7 ruas durante toda a safra de 1983.

O fato dos fornecedores terem voltado a adotar o sistema de 5 ruas já na safra de 1983 tem três prováveis ex plicações. Em primeiro lugar eles não são diretamente benefi ciados pelos ganhos de rendimento industrial que as 7 ruas pro piciam. Em segundo lugar o número de cortadores que contratam é pequeno, facilitando a mobilização e reação dos trabalhado res. Em terceiro lugar, greves de trabalhadores representam para os fornecedores a impossibilidade de entregarem suas co tas diárias de cana na usina, ocorrência que está sujeita a sanções e multas.

A manutenção pelas usinas das 7 ruas em

1983

fez com que a safra daquele ano apresentasse um nível de ten são elevado entre trabalhadores e empresários. Os bóias-frias foram obrigados a aceitar as 7 ruas, mas se percebia entre 
eles um descontentamento generalizado, quase unânime. Em to das as reuniões de trabalhadores realizadas naquela fase inva riavelmente as discussões se encaminhavam para as conseqüen cias prejudiciais que a passagem das 5 para 7 ruas estava cau sando no rendimento diário e no desgaste físico do cortador.

A tensão gerada pelas 7 ruas veio a explodir no início de 1984 com a revolta dos bóias-frias em Guariba, sendo que outros dois fatores contribuíram para a revolta dos traba lhadores.

Os bóias-frias estavam saindo do período de en tressafra, no qual as oportunidades de emprego diminuem e os salários caem. Mesmo aqueles bóias-frias componentes das tur mas fixas das usinas tiveram no final da entressafra 20 dias de férias não remuneradas, o que reduziu seus salários. Foi comum os trabalhadores em Guariba receberem no mês de abril (último mês de entressafra) salários variando entre Cr\$35.000 a Cr\$ 40.000, abaixo do salário mínimo da época (Cr\$ 57.100).

Um agravante deste nível salarial rebaixado fo ram as altas contas d'água cobradas aos trabalhadores na cida de de Guariba, em média em torno de Cr\% 20.000 a Cr\$25.000. Isto, inclusive, vinha fazendo com que a Prefei tura Municipal estivesse tendo que subsidiar o pagamento dessas taxas para muitos trabalhadores.

O bóia-fria tem sempre a expectativa de que na safra conseguirá recuperar-se dos baixos salários e do desem prego da entressafra. As 7 ruas contrariava, até certo ponto, esta expectativa, daí a reação imediata, ocorrida logo no in cio da safra, contra este sistema de corte.

Uma das características básicas do movimento de 
Guariba foi que não houve organização prévia, pelo menos orga nização patrocinada pelo Sindicato de Trabalhadores Rurais (STR) ou por outras entidades como a Comissão Pastoral da Ter ra (CPT). O movimento se iniciou no próprio local de traba tho, com uma turma de bóias-frias da Usina São Martinho (USM) parando o corte e incentivando outras turmas a fazerem o mesmo* Rapidamente toda uma frente de trabalho, constituída por traba Ihadores de Guariba, estava parada.

Fato que merece destaque é que a USM é vista pe los próprios trabalhadores como "modelo", onde todos querem trabalhar, pois é a usina que paga melhor, que rouba menos na produção do cortador e na qual a quase totalidade dos trabalha dores constituem turmas fixas. Até mesmo neste "modelo" a si tuação estava insustentável, as 7 ruas haviam ult́rapassados os limites físicos dos cortadores, o esforço extra que tinham que fazer para manter seus níveis de rendimento no corte saia-lhes muito caro em termos de sua saúde e de seu corpo.

A interrupção do corte naquela frente de traba Tho da USM aconteceu de manhã. 'A noite, na cidade de Guariba, o movimento foi engrossado pela adesão de outras frentes de trabalho da USM, bem como por trabalhadores de outras usinas e até mesmo de fornecedores. Todos eles eram prejudicados pelas 7 ruas e pelos baixos salários e, a partir do momento que se iniciou o movimento grevista, este se espalhou rapidamente en tre os trabalhadores.

Na manhã seguinte nenhum caminhão de turma saiu para a roça e os trabalhadores se aglomeraram na praça princi pal da cidade. Nesta hora, o movimento atingiu característi cas violentas com a ocorrência de depredação, principalmente 
contra o prédio da SABESP, saques contra supermercados e tro ca de tiros entre policiais e trabalhadores, com alguns bóiasfrias sendo feridos a bala e um morador da cidade morto.

A partir desta explosão inicial na cidade de Guariba, o movimento se espraiou rapidamente e sem nenhuma or ganização por toda a região canavieira de Ribeirão Preto. Em várias outras cidades os saques foram verificados, assim como a ocorrencia de conflitos entre trabalhadores e policiais.

De imediato as usinas suspenderam o corte de cana por 7 ruas. Mas aí os trabalhadores, já mais organizados e assessorados, especialmente por representantes da Federação dos Trabalhadores Agrícolas do Estado de São Paulo (FETAESP), passaram a reivindicar outras melhorias, principalmente aumen to salarial. Teve início então um processo, até o momento inédito na região, de negociação entre os trabalhadores e os usineiros e fornecedores.

Este processo de negociação foi marcado e condi cionado pela revolta violenta e ampla dos trabalhadores que atingiu várias cidades da região. Inclusive, dada certa relu tância inicial dos usineiros em querer negociar com os traba lhadores, foram praticados atos de sabotagem como a queima de canaviais, além de ameaças de se queimar as próprias unidades industriais das usinas, o que foi impedido pelo emprego de nu meroso contingente policial.

0 acordo foi conseguido 5 dias após ter se in ciado o movimento, sendo que a discussão final ocorreu na cida de de Jaboticabal, com a participação de uma Comissão de Gre ve, de representantes do Sindicato de Trabalhadores Rurais e representantes de usineiros e fornecedores, intermediada pela 
Secretaria do Trabalho do Estado de São Paulo.

As principais conquistas dos trabalhadores fo ram a volta do corte de cana por 5 ruas, o aumento no preço da tonelada cortada e maior controle sobre a produção diária* Além disso, os patrões ficaram obrigados a fornecerem podão, lima, macacão, luvas e proteção de couro para pernas, pagar os dias em que o bóia-fria não pode trabalhar por motivos de doen ça, manter na lavoura remédios e primeiros socorros etc. Em contraposição, a classe patronal nada cedeu no que se refere à medida da produção diária do corte que continua sendo feitanas balanças da usina, longe do controle direto dos trabalhadores. - acordo foi referendado por uma assembléia no estádio municí pal de Guariba por cerca de 5,000 bóias-frias.

\subsubsection{A Revolta de Bebedouro.}

O movimento de apanhadores de laranja em Bebe douro ocorreu na mesma época que o movimento de Guariba, no mês de maio de 1984, quando se iniciava a safra de laranja. Di ferentemente de Guariba, entretanto, o movimento de Bebedouro apresentou uma organização prévia, existindo uma comissão de trabalhadores que conduziu o processo reivindicatório. Esta comissão, inclusive, foi responsável pela pressão feita junto aos diretores do Sindicato de Trabalhadores Rurais de Bebedou ro para que viessem dar apoio ao movimento.

A reivindicação básica era a elevação do preço da caixa colhida de laranja de $\operatorname{cr} \$ 60$ para $\operatorname{cr} \$ 200$. 0 primei ro valor era pago no final da colheita de 1983 e no início da 
nova safra em 1984 não havia sido majorado.

A organização do movimento fica evidenciado pe lo fato de que o percentual do aumento solicitado na caixa de laranja colhida, em torno de $233 \%$, acompanhava a elevação do preço internacional do suco de laranja ocorrido no período de entressafra $83 / 84$ devido à quebra da safra de laranja norteamericana. Os trabalhadores queriam participar do aumento nos ganhos observados no setor citrícola, mesmo porque nos 5-6 me ses de entressafra seus salários haviam se deteriorado pela alta taxa de inflação do período.

o encaminhamento do movimento não foi explosivo como em Guariba, mas cumpriu várias etapas. Foram realizadas algumas assembléias e uma passeata com a presença de aproxima damente 1.500 trabalhadores. Paralelamente tentou-se entrar em acordo com os industriais do suco para elevação dos salá rios. Estes não se mostravam muito propensos a negociar e pas saram a insinuar que a culpa pelos baixos salários não era sua, mas sim das firmas empreiteiras de mão-de-obra.

Diante desta indecisão, o movimento se radica lizou e a greve foi decidida, tendo-se realizado piquetes para que os caminhões de turma não saíssem em direção às lavouras de laranja. Houve intervenção policial e o movimento assumiu características violentas com choque entre trabalhadores e po liciais.

A partir daí o processo de negociação teve in cio de fato, caracterizando-se por ser mais moroso que o de Guariba e sendo realizado na cidade de São Paulo, fora da re gi ão de conflito e longe da pressão dirèta dos trabalhadores. 
O acordo obtido estipulava que o preço da laran ja collhida seria de Cr $\mathbf{3} 144$ por caixa mais $\mathrm{Cr} \$ 66$ referentes aos direitos trabalhistas, dando um total de Cr\$210 por cai xa. Além disso, os empregadores ficaram obrigados a forne cer as sacolas de colheita, dar comprovantes diários da quanti dade de caixas colhidas, manter nos locais de trabatho medica mentos para primeiros socorros, pagar os dias em que o volante não trabalhasse por motivos independentes de sua vontade (chu va, falta de caixas, cominhão quebrado) e outras obrigacóos.

A participação do Sindicato dos Trabathadores Rurais no movimento foi dúbia e contraditória, fato que se re velou no anúncio do acordo para os trabahadores. Quando o acordo foi firmado, o Sindicato anunciou combastante alarde que havia conseguido obter Cr\$210/caixa colhida, quando os

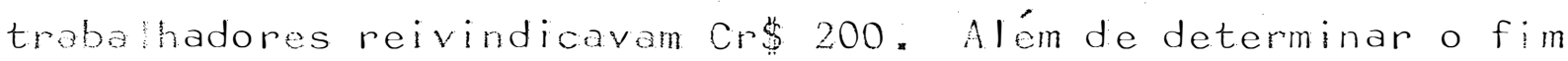
do movimento grevista, este anúncio provocou grande euforia inicial entre os trabalhadores, mas que logo se transformou em frustração ao saberem que haviam sido enganados e que no preço anunciado pelo Sindicato já estavam incluídos os direitos tra balhistas e que na verdade iriam receber somente Cr\$14A/caixa de laranja colhida. Na assembléia de apresentação do acordo havia menos que 200 trabalhadores presentes, ao passo que nas iniciais sempre existiam 1.500 a 2.000 trabalhadores.

5.2.3. Consequências e Perspectivas

Os movimentos dos bóias-frias de Bebedouro e Guariba representaram importante marcona luta ena organização 
dos trabalhadores volantes no Estado de São Paulo, pela abran gência e pelo poder de mobilização que os trabalhadores apre sentaram. Os movimentos conhecidos anteriormente na região eram de pequeno alcance, reduzindo-se, na maior parte das ve zes, à turma de um caminhão. Inicialmente nas duas cidadese, posteriormente em outras cidades da região, toda uma categoria de trabalhadores tendeu a se mobilizar, aumentando desta forma seu poder de pressão e dando grande amplitude ao movimento*

No caso dos cortadores de cana, os movimentos reivindicatórios atingiram abrangência nacional. Em uma pri meira fase, no primeiro semestre do ano de 1984, foram os tra balhadores do Centro-Sul que se mobilizaram; em outra fase, no segundo semestre, foram os cortadores de cana do Nordeste que organizaram greves e outras atividades reivindicatórias. Foram movimentos reivindicando melhores salários e, nos casos especí ficos de Goiás e São Paulo, também contrários à implantação de sistema de corte de cana por 7 ruas.

Duas entidades ligadas aos trabalhadores e que têm atuação na região junto aos bóias-friàs são a Comissão Pas toral da Terra (CPT) e o Sindicato de Trabalhadores Rurais $(S T R)$. A participação direta de ambas nos movimentos dos bóias-frias foi pequena,

O trabalho da CPT com os bóias-frias locais já vinha sendo feito há aproximadamente 5 anos. Tratava-se de promoção de reuniões de discussão, com participação de trabą lhadores e agentes de pastoral, onde a preocupação básica era fortalecer a organização dos trabalhadores, incentivando a formação de sindicatos. De prático havia se conseguido a fun dação de sindicatos de trabalhadores rurais em Dobrada (região 
da cana) e Taquaritinga (intermediária entre a cana e a laran ja). Também a CPT vinha marcando sua atuação pela denúncia de problemas envolvendo os bóias-frias, em particular o caso do corte de cana por 7 ruas. .

Entretanto, o desenvolvimento dos movimentos de Guariba e Bebedouro não foi acompanhado pela CPT. Em reunião de avaliação após a revolta dos bóias-frias os próprios mem bros da entidade reconheceram terem sido "atropelados pelos fa tos", "a entidade precisou correr atrás dos trabalhadores, acom panhar seus movimentos".

Também o STR mostrou pequeno controle sobre o movimento. Em Guariba o STR de Jaboticabal (Guariba é exten são de base) veio a participar apenas na fase de discussão do acordo, não participando de organização das greves. Já em Be bedouro, o posicionamento dos trabalhadores sempre foi adiante daquele tomado pelo sindicato; foram necessárias constantes pressões para que o sindicato participasse do movimento dos apanhadores de I aranja.

Muito mais que a ineficiência dos STR de Jaboti cabal e Bebedouro (dirigidos por presidentes "vitalícios" há mais de 15 anos), os movimentos dos bóias-frias foram importan tes para reforçar ou mesmo revelar aos trabalhadores o pa pel político que deve ser ocupado pelo sindicato. Não mais uma entidade assistencialista, mas uma entidade que encampe e organize as reivindicações dos trabalhadores.

A questão sindical tem vindo à tona em todas as reuniões de trabalhadores ao lado de assuntos. anteriormente discutidos como aluguel, custo de vida, salários, etc., dando 
evidências que os volantes estão percebendo que um de seus maiores problemas é a falta de organização mais autêntica e eficiente como força reivindicatória.

Em algumas cidades onde não existe o STR, como Pitangueiras e Guariba, estão se observando movimento de traba lhadores para criação da entidade. São sindicatos que estão surgindo marcados pelo movimento de Guariba e Bebedouro e que provavelmente terão atuação mais efetiva junto aos bóiasfrias que os STR de Jaboticabal e Bebedouro, por exemplo. Mes mo estes começam a se sentir pressionados a alterarem sua atua ção, tentando acompanhar mais de perto os movimentos dos traba Ihadores.

Os empresários, diante dos acontecimentos de Guariba e Bebedouro, apresentaram dois níveis básicos de rea ção. Um foi o de estabelecer represálias contra os trabalha dores. Assim, no caso da cana, aumentou-se a exigência e fís calização no serviço de corte da cana, tentando-se compensar com isto a queda das 7 ruas. Também, os trabalhadores denun ciam constantemente que algumas usinas aumentaram a taxa de "roubo" na conversão de metros de cana cortada em toneladas. E, de forma velada, circulam na região ameaças de dessiminação do uso de colhedeira mecânica de cana já na safra de 1985.

o outro nível de reação dos empresários foi o de reavaliar e modificar suas relações com os bóias-frias. Até então eles não se preocupavam em negociar com os trabalhado

*I Isto fez com que, inclusive, ocorressem mais dois movimen tos grevistas em usinas da região, já sem a cobertura in $\bar{i}$ cial da imprensa....... 
res; mesmo quando da implantação das 7 ruas percebeu-se o auto ritarismo dos empresários exteriorizado na seguinte frase: "são os diretores, os administradores, os técnicos que preci sam aceitar as 7 ruas e não o cortador, porque este apenas cum pre ordens", que consta de um documento precursor das 7 ruas na regi ão. O trabalhador revelou que não apenas cumpre ordens, mas que também reage, às vezes, violentamente.

Os fornecedores e usineiros, especialmente es tes, sempre relutantes em discutir com os trabalhadores, após Guariba e Bebedouro, tenderam a mudar esta postura e passaram a negociar mais diretamente com os trabalhadores. 0 ano 1984 foi o primeiro em que os representantes patronais compareceram às reuniões que antecedem o eventual julgamento do dissídio co letivo dos cortadores de.cana.

$\mathrm{Na}$ procura de maior entendimento com os traba Ihadores, os empresários têm, inclusive, procurado cooptar as novas lideranças surgidas nos movimentos. Em pelo menos um dos casos, na cidade de Taquaritinga, eles obtiveram sucesso sendo que o Sindicato Rural (patronal) da cidade forneceu a sede para o Sindicato de Trabalhadores Rurais e mantém a famí lia de seu presidente.

A reação do Governo Federal aos movimentos de Guariba e Bebedouro não foi muito grande, pelo menos de forma aparente. Foi reforçada a idéia de criação das Cooperativas de Trabalhadores Volantes, patrocinadas pelo Ministério do Tra balho, na região dos conflitos. Pelo menos três cidades da região, Sertãozinho, Guariba e Taquaritinga,já contam com pla nos ou vêm instalando as citadas cooperativas. Em Taquaritin ga, a Cooperativa já se encontra constituída, com diretoria 
eleita e atuando em conjunto com o Sindicato de Trabalhadores Rurais.

Dos acordos estabelecidos entre bóias-frias e empresários rurais vários ítens não foram cumpridos durante a safra de 1984. De prático e no geral os cortadores de cana conseguiram a volta das 5 ruas e elevação salarial e os apanha dores de I aranja tiveram seus salários aumentados. Uma recla mação que permanece generalizada entre os cortadores de cana e os apanhadores de laranja é que eles ainda têm pouco controle sobre sua produção, o que dá margem a descontos espúrios por parte de empreiteiros e empresários.

Os movimentos de Guariba e Bebedouro apresenta ram vários desdobramentos, entre eles a ocorrencia de uma se gunda greve dos apanhadores de laranja no final da safra de 1984. As relações entre trabalhadores e empresários da cana e da laranja mudam necessariamente após Guariba e Bebedouroi, pro vavelmente com tendência a se melhorar a organização e se re forçar as entidades representativas de parte a parte. 
Na agricultura do município de Jaboticabal, ao longo dos anos, duas culturas assumiram maior destaque. Do úl timo cartel do século XIX até por volta de 1930, o café predo minou na ocupação da área agrícola local e de 1950 em diante caracterizou-se a fase canavieira, com a grande expansão da ca na-de-açúcar. Intermediariamente, de 1930 a 50, houve uma fa se policultora com destaque para o algodão e o milho.

Tanto no desenvolvimento da cultura cafeeira quanto no desenvolvimento da cultura canavieira a concentração da posse e da propriedade da terra se manteve alta no municí - Ambas as culturas, em suas devidas épocas, necessitavam ou necessitam de grande contingente de trabalhadores, especial mente para a realização dos serviços da colheita.

No café este contingente era suprido através do 
sistema de colonato, com o trabalhador morando na fazenda, rea lizando a colheita, e na entressafra se dedicando a serviços diversos no café - onde a necessidade de mão-de-obra não era tão grande quanto na colheita - e no restante do tempo prati cando cultivo de subsistência nas entrelinhas do café ou em áreas anexas.

Já na cultura da cana-de-açúcar a necessidade de mão-de-obra na colheita é suprida basicamente, nos dias de hoje, pela utilização de trabalhadores volantes ou bóias-frias, moradores da cidade e que são remunerados exclusivamente atra vés de salários monetários.

A passagem do colono ao bóia-fria foi o direcio namento básico constatado na evolução das relações de trabalho no município de Jaboticabal. Esta passagem foi intermediada por uma fase onde a parceria teve significativa importância, especialmente na cultura do algodão.

A evolução das relações de trabalho se deveu a uma série de transformações pela qual passou a agricultura do município, como a incorporação de tecnologia mecânica que impe diu o cultivo nas entrelinhas da cultura principal e diminuiu a necessidade de mão-de-obra nas operações agrícolas, a valori zação da terra que tornou anti-econômica a concessão de áreas para cultivo de subsistência e a formação de um mercado de tra balho constituído por ex-colonos que, morando nas cidades, aí não se empregam definitivamente, ficando disponíveis para os serviços agrícolas nas épocas de maiores necessidades de mäode-obra.

Atualmente, a maior parte da força de trabalho utilizada na agricultura do município se constitui de trabalha 
dores volantes, empregados especialmente pela cultura da canade-açúcar e secundariamente pela laranja. Na colheita destas duas culturas o mercado de volantes se apresenta mais organiza do,com maior formalidade de yínculos empregatícios, maior esta bilidade de emprego e eliminação do empreiteiro individual de mão-de-obra. Já na entressafra para a maior parte dos volantes o mercado de trabalho se torna instável, informal e sob contro le direto do empreiteiro ou gato. Algumas usinas de açúcar e álcool estão avançando ainda mais na organização da força de trabalho, mantendo os trabalhadores contratados o ano inteiro, ainda que através de seguidos contratos semestrais.

o nível salarial dos volantes continua baixo, sendo que $94 \%$ dos entrevistados revelaram ganhar menos que 3 salários mínimos no período da safra. Uma reclamação constan te expressada pelos volantes foi o desgaste físico que o traba Iho rural provoca, especialmente o corte da cana.

A precariedade da existência dos volantes é re velada em suas condições de vida,destacando-se o alto nível de analfabetismo ou semi-analfabetismo verificado entre eles e o estado de desnutrição em que vivem. Foi muito comum ter-se constatado a presença da fome nas moradias dos bóias-frias.

A exploração a que os bóias-frias estão submeti dos, perfeitamente caracterizada por suas precárias condições de vida, faz com que a categoria represente um foco de constan te tensão social, com o trabalhador percebendo sua realidade como necessitando de mudanças imediatas. O caráter disperso do trabalho dos bóias-frias, observado especialmente na entres safra e a comṕetição entre os trabalhadores pelos empregos existentes dificultam a mobilização e realização de movimentos 
reivindicatórios por parte da categoria. Entretanto, o desen volvimento da cultura da cana-de-açúcar e também da laranja, praticamenţe como monoculturas, cria condições para que os vo lantes realizem movimentos reivindicatórios amplos. Ocorre identificação de grande número de volantes como cortadores de cana ou apanhadores de laranja e, a organização da mão-de-obra observada nas safras destas duas culturas que objetiva, em úl tima instância, permitir um fornecimento contínuo de matériaprima às agroindústrias produtoras de açúcar e álcool ou de suco de laranja, contraditoriamente, possibilita à mão-de-obra maior poder de mobilização e de direcionamento dos seus movi mentos reivindicatórios.

Os movimentos dos apanhadores de laranja inicia do na cidade de Bebedouro e dos cortadores de cana iniciado na cidade de Guariba na safra de 1984 refletiram esta nova reali dade. Foram movimentos amplos e abrangentes que se espalharam rapidamentè por toda a região citrícola e canavieira e que mobilizaram praticamente toda a categoria dos trabalhadores volantes. Basicamente foram movimentos pouco organizados, não apresentando condução centralizada, sendo que especialmente na cidade de Guariba assumiu um caráter bastante explosivo.

A partir daí se alteram necessariamente as rela ções entre proprietários e trabalhadores volantes, com tendên cia ao fortalecimento dos órgãos representativos de parte a parte e generalização de negociações coletivas das condições de trabalho dos bóias-frias da cana-de-açúcar e da laranja. 
ÂNGELO, C.F. de, 1980. Absorção de mão-de-obra no setor in dustrial. Estudos Econômicos IPE-USP. São Paulo, 10 (1): 7 I -97 .

ANTUNIASSI, M.H.R. de, 1976. Contribuição ao estudo das relä ções de produção no meio rural. In. II Reunião Nacional de Mão-de-Obra Volante na Agricultura, Botucatu, Departamento de Economia Rural.

AZZI, G.M., 1972. Incidência de matéria estranha no proces sos de carregamento da cana-de-açúcar. Piracicaba, ESALQ/ USP, 105 p. (Tese de Doutoramento). 
BACCARIN, J.G.; SOUSA, A.0.; GEBARA, J.J. e ZOCOLLER, M. M. (1984). Processo de intermediação de mão-de-obra e a coope rativa de bóias-frias. Jaboticabal, 17 p. (Mimeo).

BARBAN, V. (1983) :- 0 trabalhador rural da agroindústria ca navieira empresarial do Estado de São Paulo - pontos para discussão. São Paulo, 14 p. (Mimeo).

BRANT, V.C., 1977. Do colono ao bóia-fria: transformações na agricultura e constituição do mercado de trabalho na Alta So rocabana de Assis. Estudo CEBRAP, São Paulo, 19:37-91.

DEE (Departamento Estadual de Estatística), 1940. Anuário Es. tatístico do Estado de São Paulo, São Paulo, $1056 \mathrm{p}$.

D'INCAO E MELLO, M.C., 1975. O bóia-fria: acumulação e misé ria. Petrópolis, Vozes. $154 \mathrm{p}$.

D'INCAO, M.C., 1984. Bóia-fria, sangue quente. Folha de São. Paulo, São Paulo, 2 de junho p. 35.

FETAEG, Federação dos Trabalhadores na Agricultura do Estado de Goiás, 1977. Obóia-fria no Estado de Goiás. Goiânia, Ed. Roriz.

FIBGE (Fundação Instituto Brasileiro de Geografia e Estatísti ca), 1950. Censos Econômicos de 1940. São Paulo, Parte XVII, Tomo 3. Rio de Janeiro, $601 \mathrm{p}$. 
FIBGE, 1955. Censo Agrícola de 1950. São Paulo, Vol. XXV. Tomo 2. Rio de Janeiro, $485 \mathrm{p}$.

FIBGE, 1967. Censo Agrícola de 1960. São Paulo, Vol. II, To mo XI, 2a Parte.- Rio de Janeiro, $511 \mathrm{p}$.

FIBGE, 1975. Censo Agropecuário de 1970. São Paulo, Vol. 1II, Tomo XVIII, Ia, 2a e 3 a Partes. Rio de Janeiro,1043 p.

FIBGE, 1979. Censo Agropecuário de 1975. São Paulo, Vol, I. Tomo XVIII, Ia e 2a Partes. Rio de Janeiro, 1695 p.

FIBGE, 1984. Censo Agropecuário de 1980. São Paulo, Vol.2. Tomo 3, 1a, 2a e 3a Partes. Rio de Janeiro, $1926 \mathrm{p}$.

FIBGE, 1950. Censo Demográfico de 1940. Estado de São Paulo. Rio de Janeiro.

FIBGE, 1955. Censo Demográfico de 1950. Estado de São Paulo. Rio de Janeiro.

FIBGE, 1965. Censo Demográfico de 1960. Estado de São Paulo. Rio de Janeiro.

FIBGE, 1982. Censo Demográfico de 1980. Estado de São Paulo. Rio de Janeiro.

FLEURY, M.T.L.; FERREIRA, R.M.F. e FISChER, A.L., (1983). Pro cesso e organização do trabalho na agroindústria canavieira. São Paulo, $17 \mathrm{p}$. (Mimeo). 
FREITAS, G.P., 1977. O acidente "in itinere" e o trabalhador rural volante "bóia-fria". In: 11 Reunião Nacional de Mãode-Obra Volante na Agricultura, Botucatu, Departamento de Economia Rural, p. 328-336.

FREITAS, G.P. e ARANHA, N.M.P., 1975. "Bóia-fria", problemas, soluções. In: I Reunião Nacional de Mão-de-Obra Volante na Agricultura, Botucatu, Departamento de Economia Rural.

GEBARA, J.J., 1976. A estrutura agrária no município de Ser tãozinho (SP) - evolução, caracterização e efeitos. São Pau Io, EAESP/FGV, $85 \mathrm{p}$. (Tese de Mestrado).

GEBARA, J.J. e BACCARIN, J.G., 1983. O novo sistema de corte de cana por 7 ruas: quem ganha? Série Estudos no 8. Jabo ticabal, Departamento de Economia Rural, 9 p.

GEORGESCU-ROEGEN, N., 1970. Uma análise crítica da função de produção neoclássica. 0 processo de produção na indústria e agricultura. Revista de Teoria e Pesquisa Econômica, São Paulo, I (1): $11-35$.

GNACCARINI, J.C., 1980. Latifúndio e proletariado (formação da empresa e relações de trabalho no Brasil Rural). São Pau Io, Editora Polis, $185 \mathrm{p}$.

GONZALES, E. e BASTOS, M.J., 1977. O trabalho volante na agricultura brasileira. In: PINSKY, J*, Org. Capital e Tra balho no Campo: São Paulo, HUCITEC, P. 25-48. 
GRAZIANO DA SILVA, J., 1981. Progresso técnico e relações de trabalho na agricultura. São Paulo, HUCITEC. $210 \mathrm{p}$.

GRAZIANO DA SILVA, J., 1982,. O "bóia-fria" entre aspas e com os pingos nos is.- In: Departamento de Economia Rural - FCA de Botucatu, 0rg. A Mão-de-Obra Volante na Agricultura, São Paulo, CNPq/UNESP/POLIS, P. 137-177.

GRAZIANO DA SILVA, J. e FREITAS, G.P., 1976. Os volantes da Zona de Avaré e Cerqueira César. In: II Reunião Nacional de Mão-de-Obra Volante na Agricultura, Botucatu, Departamento de Economia Rural.

GRAZIANO DA SILVA, J. e GASQUES, J.G., 1982. Diagnóstico ini cial do volante em São Paulo. In: Departamento de Economia Rural - FCA de Botucatu, Org. A Mão-de-Obra Volante na Agri cultura. São Paulo, CNPq/UNESP/POLIS, p. 85-125.

IAA (Instituto do Açúcar e Álcooi). Boletim de Safra - resul tado final. São Paulo, diversos números.

IANNI, 0., 1976. Relações da produção e proletariado rural. In: SZMRECSANYI, T. e QUEDA, 0., Org vida Rural e Mudança Social. São Paulo, Companhia Editora Nacional, P: 148-159.

IANNI, 0., 1976. A classe operária vai ao campo. Caderno. CEBRAP 24. São Paulo, Editora Brasiliense. $64 \mathrm{p}$.

IANNI, 0., 1977. Notas sobre o bóia-fria. Escrita Ensaio. São Paulo, $1(2): 40-45$. 
IEA (Instituto de Economia Agrícola), 1982. Prognóstico 1982/. 83. São Paulo, Secretaria da Agricultura. $255 \mathrm{p}$.

IEA, 1983. Previsões e Estimativas das. Safras Agrícolas do Estado de São Paulo 1982/83. São Paulo, Secretaria da Agri cultura. 5o levantamento - junho.

LANGE, A.M.; BELLOTTO, H. e BASTOS, M.I., 1982. O trabalho rural volante na agricultura paranaense: esboço de uma hipó tese de trabalho. In: Departamento de Economia Rural - FCA Botucatu, Org. A Mão-de-Obra Volante na Agricultura. São Paulo, CNPq/UNESP/POLIS, p. 127-137.

KAGEYAMA, A.A., 1982. O emprego temporário na agricultura brasileira: seus determinantes e sua evolução recente. Re forma Agrária. Campinas, 12 (5):3-12.

MARTINEZ-ALIER, V., 1977. As mulheres do caminhão de turma. In: PINSKY, J., Org. Capital e Trabalho no Campo. São Pau Io, HUCITEC, P. 69-100.

MARTINS, J. de S., 1980. Expropriação e violência: a questão. política no campo. São Paulo, HUCITEC. $181 \mathrm{p}$.

MARX. K., 1982. O Capital (Crítica da Economia Política).São Paulo, DIfEL, Livro I, Vol. 2, Cap. XXI11, p. 712-827.

MICHELOTTO, A.R., 1980. Trabalho volante e reprodução capitą lista - estudo sobre os bóias-frias de Tupaciguara, MG. Pi racicaba, ESALQ/USP, 95 p. (Tese de Mestrado). 
MONTEIRO, H. et alii , 1983. "Matéria estranha": custos e téc nicas de sua diminuição na colheita. Álcool e Açúcar. São Paulo, 2 (6):20-26.

OLIVEIRA, J.F. de C. OLIVEIRA, M.H.S.D. de (Org.), 198I. Bóias-frias: uma realidade brasileira. São Paulo, CNPq/ ACIESP. $273 \mathrm{P}$.

RAMOS, P., 1983. Um estudo da evolução e da estrutura da agroindústria canavieira do Estado de São Paulo (1930-1982). São Paulo, EAESP/FGV, 258 p. (Tese de Mestrado)。

SAINT, W.S., 1980. Mão-de-obra volante na agricultura brasi leira. Pesquisa e Planejamento Econômico. Rio de Janeiro, 10 (2): 503-526.

SEADE (Fundação Sistema Estadual de Análise de Dados), 1983. Repercussões do Proálcool no comportamento migratório do Es tado de São Paulo: o caso de Ribeirão Preto. Informe Demo gráfico. São Paulo, no 10, 168 p.

SEP (Secretaria de Economia e Planejamento), 1978. Plano Re gional de Ribeirão Preto. São Paulo, Governo do Estado de São Paulo. $140 \mathrm{p}$.

SILVA, J.G., 1977. A "turma firme" de Dona Eloisa. In: 111 Reunião Nacional de Mão-de-Obra Volante na Agricultura, Botú catu, Departamento de Economia Rural, $\mathrm{P}=118-148$. 
SINGER, P., 1977. Introdução: capital e trabalho no campo. In: PINSKY, J. Capital e Trabalho no Campo. São Paulo, HU CITEC, $P .1-6$.

SOUSA, A.0. e GEBARA, J.J., (1984). A condição do homen nas relações de trabalho sob o capital. Jaboticabal, 19 p. (Mi meo).

WEBER, M., 1981. A situação dos trabalhadores rurais da Ale manha nas províncias de Além-Elba-1982. In: GRAZIANO DA SIL VA, J. e STOLCKE, V., Org. A Questão Agrária. São Paulo, Editora Brasiliense, P. 13-57.

WHITAKER, A.P. de A., 1978. Os primeiros anos de uma histó ria sesquicentenária. In: Edição do Sesquicentenário de Ja. boticabal (192.8-1978). São Paulo, Edições Populares, p. 1123.

ZAMBONI, S.P., 1978. A agricultura em Jaboticabal. In: Edi cãa do Sesquicentenário de Jaboticabal (1928-1978). São Pau lo, Edições Populares, p. 64-65.

ZAMBONI, S.P., 1979. O café no norte paulista: a crise de 1929 na Fazenda Dumont. Piracicaba, ESALQ/USP, 87 p. (Tese de Mestrado).

ZOCOLLER, M.M.; BACCARIN, J.G. e GEBARA, J.J. O processo de intermediação de mão-de-obra e qualidade de vida do trabalhạ dor volante na região de Jaboticabal. In: Conferência Lati noamericana de Economia Agrícola, Piracicaba, IAAE, 19 p. 